\title{
12. UPPER MIDDLE EOCENE TO OLIGOCENE DINOFLAGELLATE BIOSTRATIGRAPHY AND ASSEMBLAGE VARIATIONS IN HOLE 913B, GREENLAND SEA ${ }^{1}$
}

\author{
John V. Firth ${ }^{2}$
}

\begin{abstract}
Extremely diverse dinoflagellate cyst and acritarch assemblages were recovered in the upper middle Eocene to Oligocene in Ocean Drilling Program Hole 913B, off of northeast Greenland. These assemblages enable a subdivision of the sequence into: middle Eocene from 581.42 to $560.68 \mathrm{mbsf}$; middle to upper Eocene from 550.90 to $510.89 \mathrm{mbsf}$; upper Eocene from 505.15 to 464.27 mbsf; ?upper Eocene to Oligocene from 462.68 to $427.45 \mathrm{mbsf}$, an interval with few dinocysts; and Oligocene from 425.98 to 424.49 mbsf. Relative abundance peaks of Deflandrea spp. and Phthanoperidinium spp. occur through the section. Two peaks in these genera coincide with the diatom- and radiolarian-rich biosiliceous oozes between 464 and 500 mbsf. These peaks may be interpreted as possibly reflecting high paleoproductivity events, and they are used to infer at least two other possible episodes of high paleoproductivity centered around 540 and $570 \mathrm{mbsf}$ (middle to upper Eocene) in sediments wherein primary biosilica has been mostly removed or altered by diagenesis.
\end{abstract}

\section{INTRODUCTION}

As part of Ocean Drilling Program (ODP) Leg 151, a series of sites was proposed along a north-south transect near the East Greenland Margin (Myhre, Thiede, Firth, et al., 1995). Most of these proposed sites were located on relatively old (Paleogene) oceanic crust. 230Recovering Paleogene sediments at these sites, therefore, would increase our knowledge of the depositional environment of the early Norwegian-Greenland Sea, which is known only from a few sites drilled by Deep Sea Drilling Project (DSDP) Leg 38 (Talwani, Udintsev, et al., 1976) and ODP Leg 104 (Eldholm, Thiede, Taylor, et al., $1987 ; 1989)$. ODP Site 913, the only site drilled along the East Greenland Margin transect, is located on the lower slope off northeast Greenland at $75^{\circ} 29.344^{\prime} \mathrm{N}, 6^{\circ} 56.830^{\prime} \mathrm{E}$, in 3318.6 meters of water (Fig. 1). This deep site in the Greenland Basin is located on crust with an age of about $53 \mathrm{Ma}$ (magnetic Anomaly 24B; Talwani and Eldholm, 1977; Cande and Kent, 1992). The main objective for coring the Paleogene sediments at Site 913 was to study the history and variability of the early pre-glacial depositional environments of the Norwegian-Greenland Sea. In the Paleogene, this region consisted of a number of isolated basins, which allowed only shallow-water exchange with the world ocean (Myhre, Thiede, Firth, et al., 1995).

Hole 913B recovered Eocene and Oligocene age sediments between 424 and 770 meters below seafloor (mbsf), composed mostly of laminated and massive clayey silts and clays. Between about 462 and 500 mbsf is an interval composed mostly of biosiliceous clay and clayey and silty siliceous ooze, with high abundances of diatoms, radiolarians, and silicoflagellates (Myhre, Thiede, Firth, et al., 1995). Shipboard micropaleontology indicated that the biosiliceous-rich interval may span a period of time from the latest Eocene to earliest Oligocene. In addition, the sediments below about $510 \mathrm{mbsf}$ are largely barren of siliceous microfossils and the entire Paleogene section is almost barren of calcareous microfossils, with the exception of some occurrences of recrystallized, questionable Bolboforma. Agglutinated benthic foraminifers do occur through most of the section.

Thiede, J., Myhre, A.M., Firth, J.V., Johnson, G.L., and Ruddiman, W.F. (Eds.), 1996. Proc. ODP, Sci. Results, 151: College Station, TX (Ocean Drilling Program).

2Ocean Drilling Program, 1000 Discovery Drive, College Station, TX 77845-9547. U.S.A.John_Firth@odp.tamu.edu

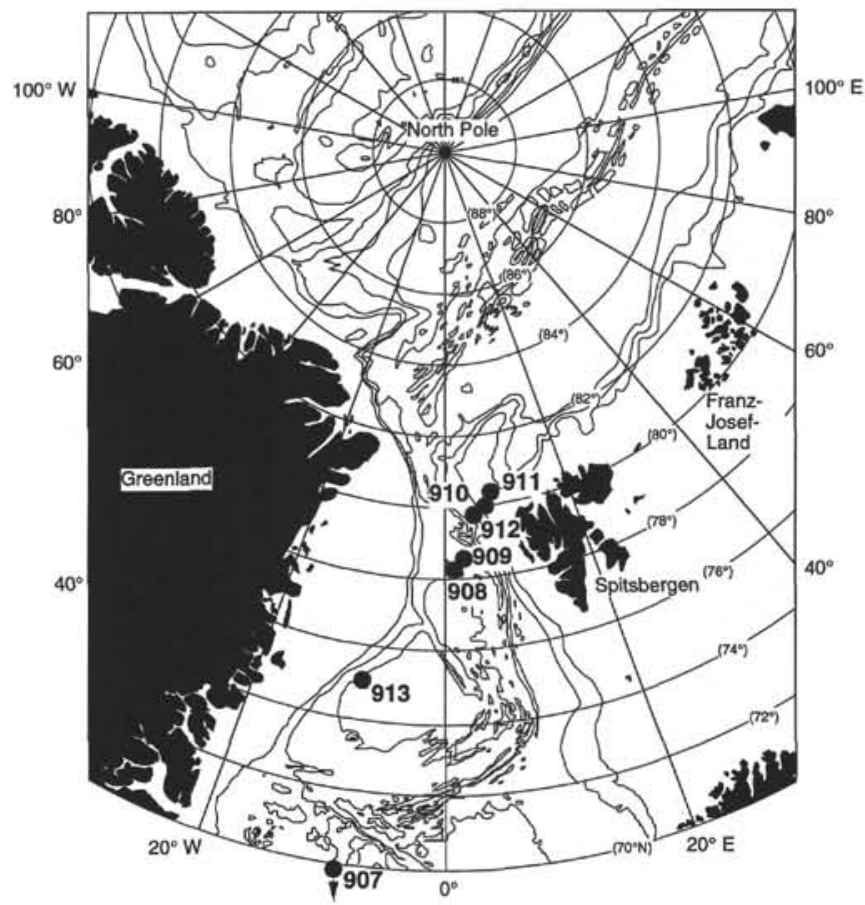

Figure 1. Map of Norwegian-Greenland Sea with locations of ODP Leg 151 sites. Bathymetry in 1000-m intervals.

Magnetostratigraphy of the Paleogene section in Hole 913B is limited by low magnetic intensities within this studied interval. Although a polarity reversal pattern was distinguished (Myhre, Thiede, Firth, et al., 1995), its correlation to the biostratigraphy as well as to the standard magnetic reversal sequence for the Eocene and Oligocene was uncertain.

Except for a nearly barren interval between 427 and $464 \mathrm{mbsf}$, the Paleogene sequence contains abundant marine organic walled phytoplankton (dinoflagellate cysts and acritarchs), as well as abundant terrestrial palynomorphs and plant debris. Because the other micro- 
fossil groups all had uncertainties in their age determinations in the middle Eocene to lower Oligocene in Hole 913B, the focus of this paper is to evaluate the dinoflagellate cyst (dinocyst) biostratigraphy between 424 and $580 \mathrm{mbsf}$, to try to determine the middle/upper Eocene and Eocene/Oligocene boundaries. In addition, dinocyst assemblage changes through this section will be discussed. The dinoflagellate biostratigraphy of the middle to lower Eocene in this hole, below $580 \mathrm{mbsf}$, as well as detailed taxonomic studies, will be the topics of future papers.

\section{METHODS}

Standard acid palynological techniques were followed for processing samples. Before processing, Lycopodium tablets were added to the samples, so that quantitative abundance estimates of marine and terrestrial palynomorphs and kerogen could be made. This data and its analysis, however, are not the subject of this paper. For this study, relative abundances of dinoflagellate taxa were determined by counts of 300 specimens per sample, in straight transects across a strewn slide. Some samples with only rare dinocysts had total counts of less than 300 . Some morphologically complex and variable species groups, such as the Areoligera complex and Spiniferites complex, were grouped together under their generic assignments. For the species distribution chart, many of the undescribed, mostly rare taxa, are grouped together under the heading "Other Dinocysts and Acritarchs." During the counts, specimens that were poorly preserved, broken, or crushed, and whose identification was not possible, were counted under the group heading "Unidentified Dinocysts." In addition to numeric counts, the entire slide from each sample was scanned, with magnifications of $200 \times$ to $2000 \times$, and all taxa present in each sample were recorded. Taxa present in a sample but not recorded in the count of 300 are listed in the species distribution chart with a "P."

All photomicrographs were taken using a video CCD camera attached to either a Zeiss Axioskop or Axiophot microscope. Video images were captured to a computer and saved as Adobe Photoshop ${ }^{\text {TM }}$ files. Adobe Photoshop ${ }^{\mathrm{TM}}$ was used to enhance contrast and brightness, as well as for recording micron scales and sample ID information with each image. Specimens were analyzed and photographed using brightfield, phase contrast, and differential interference contrast illumination. Files of each image from each plate are included on the CD-ROM in the back of this volume.

Species nomenclature follows that of Lentin and Williams (1993), and so complete references to each taxon will not be included here. Those taxa described after, or not found in, Lentin and Williams (1993) have their complete reference listed on Table 1.

\section{RESULTS General Comments}

Over 250 taxa were observed in 32 samples analyzed for this study. Many taxa are reworked from Cretaceous, Paleocene, and lower to middle Eocene strata, and are listed separately in the species distribution chart (Table 1) under the heading "Reworked Taxa." Several taxa (e.g., Pseudoceratium sp., Rhombodella paucispina, Bourkidinium sp., Surculosphaeridium longifurcatum) have been recorded from Lower Cretaceous strata outcropping on northeast Greenland, approximately $400 \mathrm{~km}$ west of Hole 913B (Nøhr-Hansen, 1993). The amount of reworking of significantly older material raises the possibility that younger material (i.e., from the middle to upper Eocene) is also reworked to some degree in this hole, thereby making stratigraphic ranges, and especially highest occurrence datums, suspect for biostratigraphic work. This will be discussed further below.

Dinocysts are mostly common to abundant and well preserved from Samples 151-913B-36R-2, 103-105 cm, up to 24R-2, 77-79 $\mathrm{cm}$ (581.44-464.27 mbsf). The diversity of obviously reworked taxa is high, but overall relative abundance is low. From Samples 913B$24 \mathrm{R}-1,68-70 \mathrm{~cm}$, up to $20 \mathrm{R}-1,99-103 \mathrm{~cm}$ (462.70-424.49 mbsf), dinocysts are mostly rare, and are poorly to moderately preserved. Reworked taxa remain diverse in this upper interval, but also increase greatly in relative abundance in a few samples (913B-21R-2, 97-101 $\mathrm{cm}$, to $20 \mathrm{R}-2,98-102 \mathrm{~cm}$ ).

Genera and species commonly used in Eocene and Oligocene biostratigraphy of Northern Europe, such as the Wetzeliellaceae, are rare in Hole 913B. This finding is similar to the results of previous studies of Norwegian-Greenland Sea and North Atlantic dinocysts (e.g., Manum, 1976; Manum et al., 1989; Costa and Downie, 1979). The most common taxa are species of the genera Deflandrea, Impagidinium, Phthanoperidinium, Spiniferites, and Operculodinium. A group of small gonyaulacoid dinocysts, including Batiacasphaera, Cerebrocysta, Corrudinium, Elytrocysta, Histiocysta, and Tectatodinium, together comprise a significant part of the assemblages. Assemblage changes through the section are marked by changing dominances between either peridinioid dinoflagellates such as Deflandrea or Phthanoperidinium, or gonyaulacoid dinoflagellates such as Spiniferites and Operculodinium. These changes will be discussed further below.

\section{Previous Paleogene Dinocyst Biostratigraphy of the Norwegian-Greenland Sea}

To determine the age of the strata based on the ranges of dinoflagellate taxa, species ranges must be compared with those of other studies. This may pose a problem, however, because dinoflagellate assemblages are provincial, and care must be taken not to make stratigraphic correlations over too wide a geographic region. On the other hand, unless many well-dated, similar biostratigraphic studies exist from the same basin or geographic region, one may be forced to rely on comparisons with studies far removed from one's own locality. In the Norwegian-Greenland Sea, two primary studies provide the bulk of the published information on Paleogene dinoflagellate biostratigraphy: Manum (1976) and Manum et al. (1989). These studies are based on previously cored DSDP and ODP holes. Many of the taxa recorded in these studies are also found in Hole 913B; however, some limitations exist when making stratigraphic comparisons with them. Manum (1976) was a ground-breaking study for dinocyst biostratigraphy in this region; the work was based on widespread sampling of many sites, but with limited stratigraphic resolution at any one site. Site 338 was studied in the most detail among all the sites in his paper. Range charts show only selected taxa, and taxon nomenclature was largely informal. This was undoubtedly because of the exploratory nature of the first DSDP leg in the region, and because species diversity was high and taxonomic work on high-latitude Paleogene dinoflagellates was rudimentary. Also, the age determinations in Manum (1976) were based mainly on comparisons with other microfossil groups such as nannofossils, silicoflagellates, and diatoms (Talwani, Udintsev, et al., 1976), as well as with comparisons with European dinoflagellate ranges. However, the stratigraphic utility of other microfossil groups in Paleogene sediments of the NorwegianGreenland Sea also suffers from limitations, such as barren intervals (e.g., the calcareous nannofossils, Müller, 1976; diatoms, Schrader and Fenner, 1976; radiolarians, Bjørklund, 1976; and silicoflagellates, Martini and Müller, 1976), lack of low-latitude zonal markers (nannofossils, Müller, 1976), or the microfossils are virtually absent (planktonic foraminifers, Talwani, Udintsev, et al., 1976). Magnetic reversal stratigraphy does not exist for the spot-cored sites of Leg 38 (Talwani, Udintsev, et al., 1976).

Manum et al. (1989) presented the next major study on Paleogene Norwegian-Greenland Sea dinoflagellate biostratigraphy, and provided much higher resolution sampling in fewer holes than the earlier DSDP work. Age determinations of their sites were again made by comparison with Northern European studies. Other microfossil groups studied from ODP Leg 104 Paleogene sediments suffered the 
Table 1. Occurrences and abundances (out of a count of up to 300 specimens per sample) of dinoflagellate and acritarch cyst taxa from Hole $913 \mathrm{~B}$.

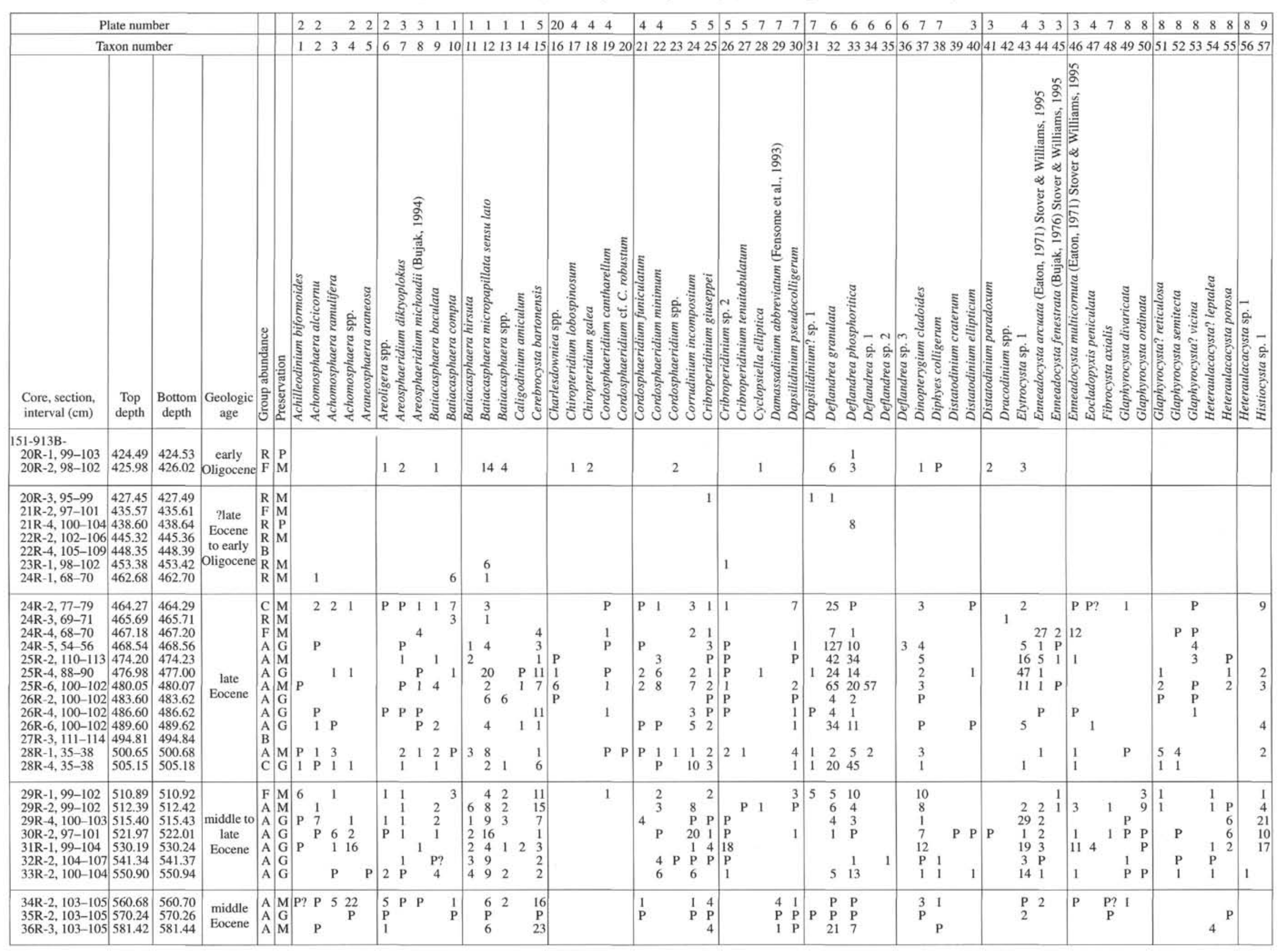




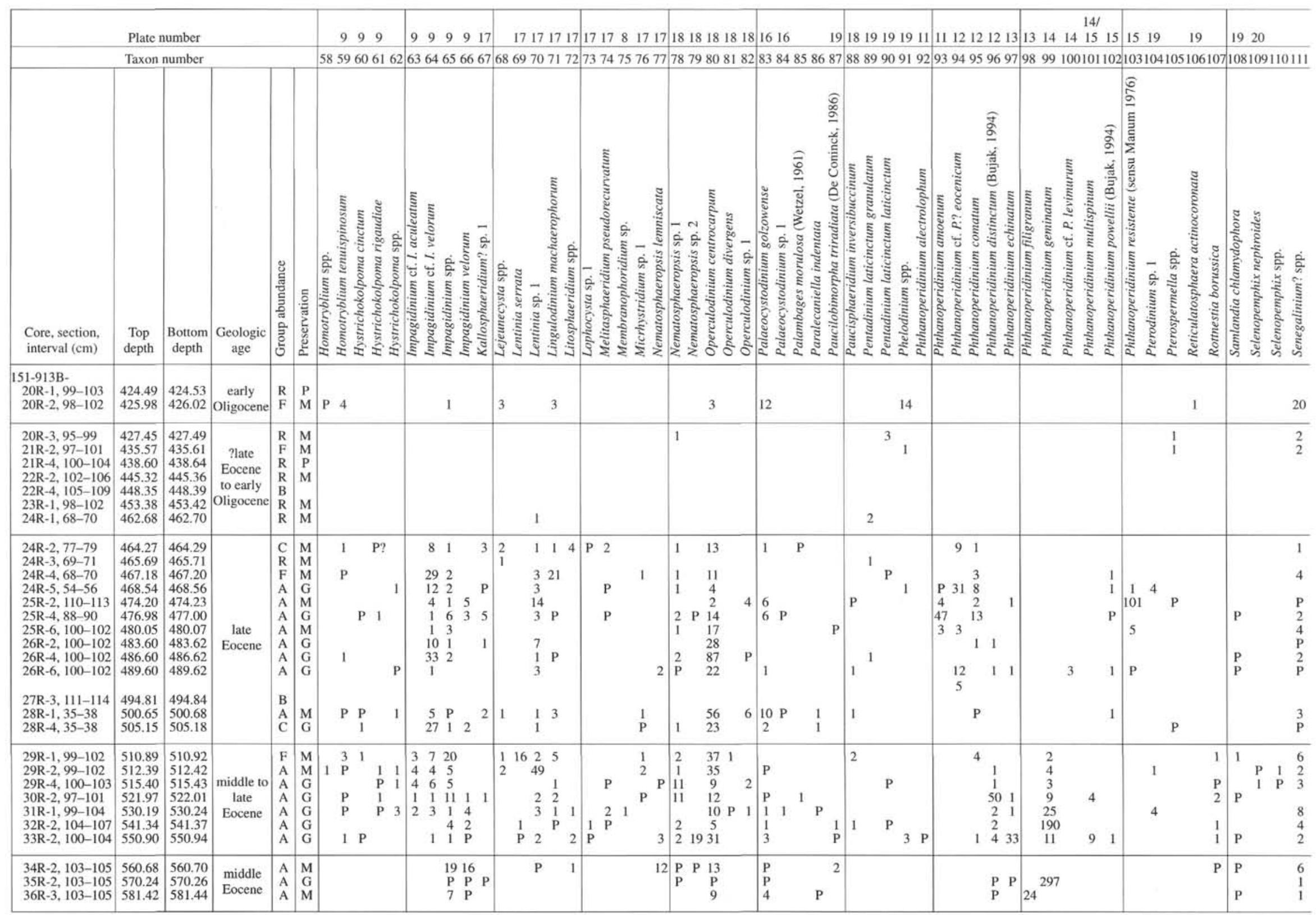


Table 1 (continued).

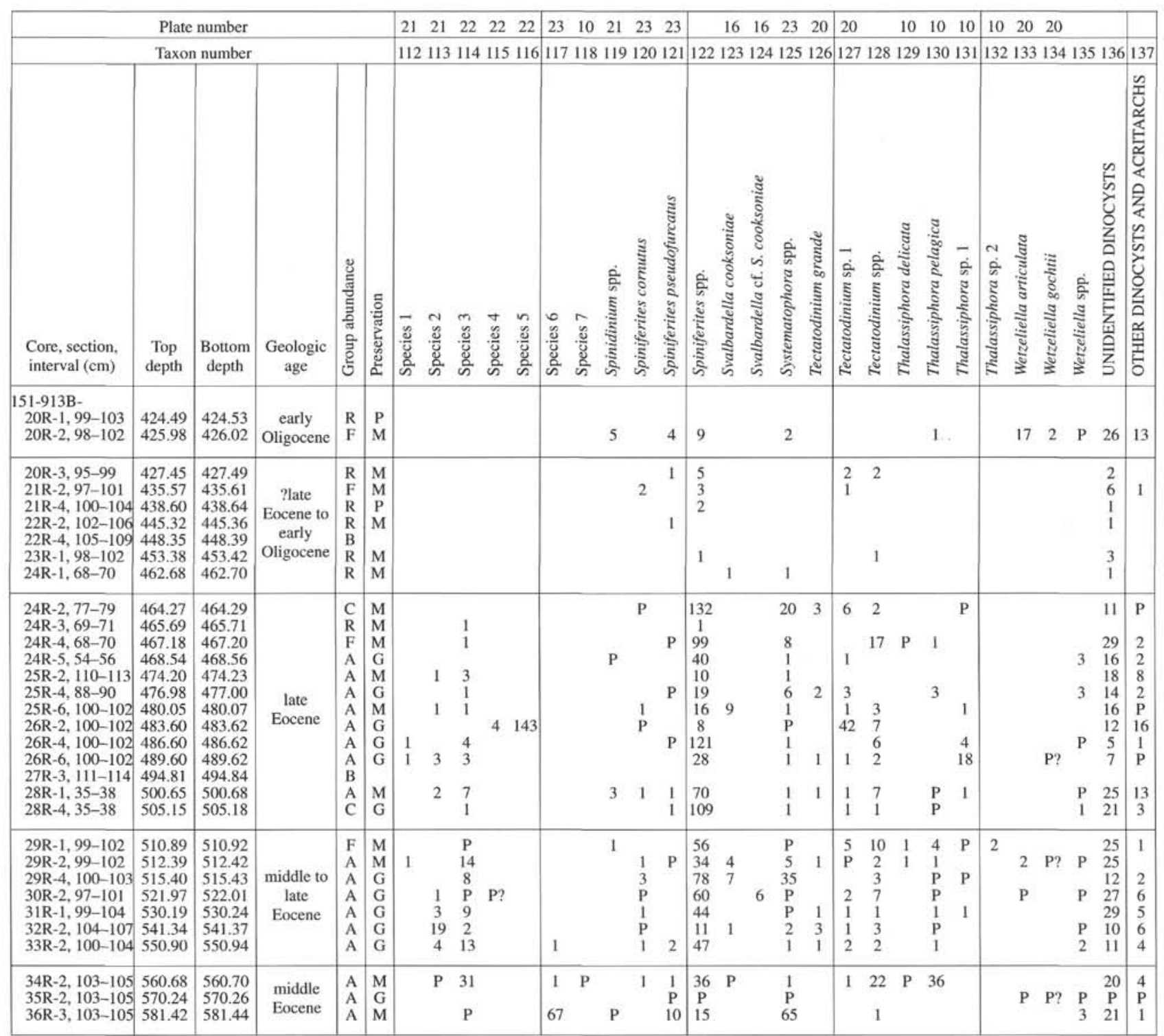


Table 1 (continued).

\begin{tabular}{|c|c|c|c|c|c|c|c|c|c|c|c|c|c|c|c|c|c|c|c|c|c|c|c|c|c|c|c|c|}
\hline \multicolumn{6}{|c|}{ Plate number } & 24 & 242 & 242 & 242 & 242 & 242 & 252 & 272 & $25 \quad 25$ & & $25 \quad 25$ & 25 & 726 & & 2626 & 26 & 26 & 262 & $27 \quad 26$ & $26 \quad 27$ & 27 & $27 \quad 27$ & \\
\hline \multicolumn{6}{|c|}{ Taxon number } & 1381 & 1391 & 1401. & 14114 & 1421 & 14314 & 1441 & 1451 & 14614 & & 48149 & 9150 & 015115 & 215 & 531541 & 155156 & 157 & 1581 & 15916 & 160161 & 1162 & 163164 & \\
\hline & & & & & & \multicolumn{23}{|c|}{ REWORKED TAXA } \\
\hline $\begin{array}{l}\text { Core, section, } \\
\text { interval }(\mathrm{cm})\end{array}$ & $\begin{array}{l}\text { Top } \\
\text { depth }\end{array}$ & $\begin{array}{c}\text { Bottom } \\
\text { depth }\end{array}$ & $\begin{array}{c}\text { Geologic } \\
\text { age }\end{array}$ & 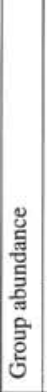 & 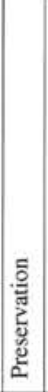 & 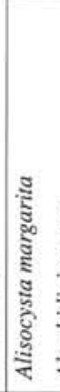 & 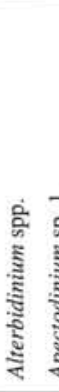 & 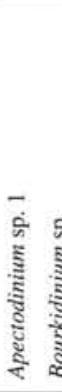 & 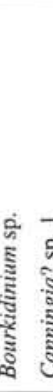 & हैं & 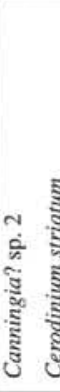 & हूँ & 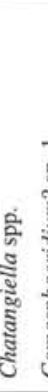 & 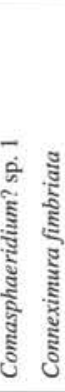 & & 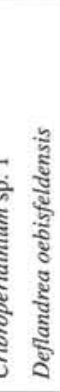 & 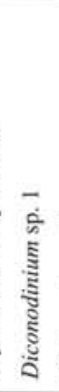 & 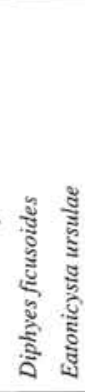 & & 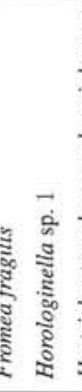 & 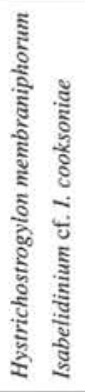 & 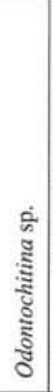 & 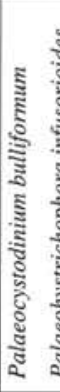 & 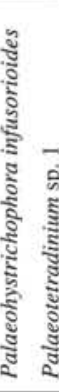 & 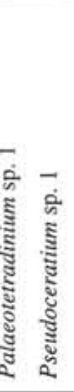 & 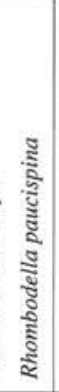 & 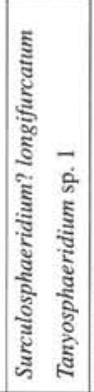 & 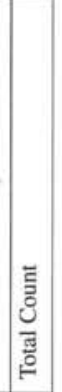 \\
\hline $\begin{array}{l}151-913 \mathrm{~B}- \\
20 \mathrm{R}-1,99-103 \\
20 \mathrm{R}-2,98-102\end{array}$ & $\begin{array}{l}424.49 \\
425.98\end{array}$ & $\begin{array}{l}424.53 \\
426.02\end{array}$ & $\begin{array}{c}\text { early } \\
\text { Oligocene }\end{array}$ & $\begin{array}{l}\mathrm{R} \\
\mathrm{F}\end{array}$ & $\begin{array}{l}\mathrm{P} \\
\mathrm{M}\end{array}$ & & 10 & 3 & & 61 & 49 & 9 & 12 & & 4 & $4 \quad 1$ & 2 & 1 & & & & & 1 & 2 & 2 & 1 & 4. & $\mid \begin{array}{c}1 \\
300\end{array}$ \\
\hline $\begin{array}{l}20 \mathrm{R}-3,95-99 \\
21 \mathrm{R}-2,97-101 \\
21 \mathrm{R}-4,100-104 \\
22 \mathrm{R}-2,102-106 \\
22 \mathrm{R}-4,105-109 \\
23 \mathrm{R}-1,98-102 \\
24 \mathrm{R}-1,68-70\end{array}$ & $\begin{array}{l}427.45 \\
435.57 \\
438.60 \\
445.32 \\
448.35 \\
453.38 \\
462.68\end{array}$ & $\begin{array}{l}427.49 \\
435.61 \\
438.64 \\
445.36 \\
448.39 \\
453.42 \\
462.70\end{array}$ & $\begin{array}{c}\text { ?late } \\
\text { Eocene to } \\
\text { early } \\
\text { Oligocene }\end{array}$ & $\begin{array}{l}\mathrm{R} \\
\mathrm{F} \\
\mathrm{R} \\
\mathrm{R} \\
\mathrm{B} \\
\mathrm{R} \\
\mathrm{R}\end{array}$ & $\begin{array}{l}\mathrm{M} \\
\mathrm{M} \\
\mathrm{P} \\
\mathrm{M}\end{array}$ & & 2 & & & & 1 & 1 & $\begin{array}{l}6 \\
6\end{array}$ & & & & $\begin{array}{l}1 \\
1\end{array}$ & & & & & & $\begin{array}{l}1 \\
1\end{array}$ & & & & 1 & $\begin{array}{c}33 \\
26 \\
11 \\
3 \\
13 \\
15\end{array}$ \\
\hline $\begin{array}{l}24 \mathrm{R}-2,77-79 \\
24 \mathrm{R}-3,69-71 \\
24 \mathrm{R}-4,68-70 \\
24 \mathrm{R}-5,54-56 \\
25 \mathrm{R}-2,110-113 \\
25 \mathrm{R}-4,88-90 \\
25 \mathrm{R}-6,100-102 \\
26 \mathrm{R}-2,100-102 \\
26 \mathrm{R}-4,100-102 \\
26 \mathrm{R}-6,100-102 \\
27 \mathrm{R}-3,111-114 \\
28 \mathrm{R}-1,35-38 \\
28 \mathrm{R}-4,35-38\end{array}$ & $\begin{array}{l}464.27 \\
465.69 \\
467.18 \\
468.54 \\
474.20 \\
476.98 \\
480.05 \\
483.60 \\
486.60 \\
489.60 \\
494.81 \\
500.65 \\
505.15\end{array}$ & \begin{tabular}{|l|}
464.29 \\
465.71 \\
467.20 \\
468.56 \\
474.23 \\
477.00 \\
480.07 \\
483.62 \\
486.62 \\
489.62 \\
494.84 \\
500.68 \\
505.18
\end{tabular} & $\begin{array}{c}\text { late } \\
\text { Eocene }\end{array}$ & $\begin{array}{ll}\mathrm{C} \\
\mathrm{R} \\
\mathrm{F} \\
\mathrm{A} \\
\mathrm{A} \\
\mathrm{A} \\
\mathrm{A} \\
\mathrm{A} \\
\mathrm{A} \\
\mathrm{A} \\
\mathrm{B} \\
\mathrm{A} \\
\mathrm{C}\end{array}$ & \begin{tabular}{|l|}
$\mathrm{M}$ \\
$\mathrm{M}$ \\
$\mathrm{M}$ \\
$\mathrm{G}$ \\
$\mathrm{M}$ \\
$\mathrm{G}$ \\
$\mathrm{M}$ \\
$\mathrm{G}$ \\
$\mathrm{G}$ \\
\end{tabular} & P & $\begin{array}{l}1 \\
1 \\
1\end{array}$ & & & 2 & & & $\begin{array}{l}1 \\
1\end{array}$ & 3 & $\mathrm{P}$ & 1 & 1 & 1 & & $\mathbf{P}$ & 1 & 1 & 1 & $\begin{array}{l}1 \\
2\end{array}$ & & $\begin{array}{l}1 \\
1\end{array}$ & $\begin{array}{ll}4 & 1 \\
3 & 2 \\
\mathrm{P} & 1 \\
\mathrm{P} & 2 \\
1 & \\
\mathrm{P} & \\
4 & 2\end{array}$ & $\begin{array}{c}300 \\
9 \\
300 \\
300 \\
300 \\
300 \\
300 \\
300 \\
300 \\
300 \\
300 \\
300 \\
30\end{array}$ \\
\hline $\begin{array}{l}29 \mathrm{R}-1,99-102 \\
29 \mathrm{R}-2,99-102 \\
29 \mathrm{R}-4,100-103 \\
30 \mathrm{R}-2,97-101 \\
31 \mathrm{R}-1,99-104 \\
32 \mathrm{R}-2,104-107 \\
33 \mathrm{R}-2,100-104\end{array}$ & $\begin{array}{l}510.89 \\
512.39 \\
515.40 \\
521.97 \\
530.19 \\
541.34 \\
550.90\end{array}$ & \begin{tabular}{|l|}
510.92 \\
512.42 \\
515.43 \\
522.01 \\
530.24 \\
541.37 \\
550.94 \\
\end{tabular} & $\begin{array}{l}\text { middle to } \\
\text { late } \\
\text { Eocene }\end{array}$ & \begin{tabular}{|l|}
$\mathrm{F}$ \\
$\mathrm{A}$ \\
$\mathrm{A}$ \\
$\mathrm{A}$ \\
$\mathrm{A}$ \\
$\mathrm{A}$ \\
$\mathrm{A}$ \\
\end{tabular} & \begin{tabular}{l|}
$M$ \\
$M$ \\
$G$ \\
$G$ \\
$G$ \\
$G$ \\
$G$
\end{tabular} & & $\begin{array}{l}1 \\
1\end{array}$ & & 1 & 1 & & $\begin{array}{l}\mathrm{P} \\
2\end{array}$ & $\begin{array}{l}1 \\
1\end{array}$ & & & $\begin{array}{l}\mathrm{P} \\
\mathrm{P}\end{array}$ & & P & & $\begin{array}{ll}1 & P \\
& \\
& 1\end{array}$ & 1 & $\begin{array}{l}2 \\
\mathrm{P}\end{array}$ & 1 & $\begin{array}{ll}3 & \\
1 & 2 \\
& P\end{array}$ & 2 & & \begin{tabular}{ll|l|}
1 & \\
& \\
& 2 \\
& \\
1 & 1 \\
\end{tabular} & \begin{tabular}{|l|}
300 \\
300 \\
300 \\
300 \\
300 \\
300 \\
300
\end{tabular} \\
\hline $\begin{array}{l}34 \mathrm{R}-2,103-105 \\
35 \mathrm{R}-2,103-105 \\
36 \mathrm{R}-3,103-105\end{array}$ & $\begin{array}{l}560.68 \\
570.24 \\
581.42\end{array}$ & \begin{tabular}{|l|}
560.70 \\
570.26 \\
581.44
\end{tabular} & $\begin{array}{l}\text { middle } \\
\text { Eocene }\end{array}$ & \begin{tabular}{|l|}
$\mathrm{A}$ \\
$\mathrm{A}$ \\
$\mathrm{A}$
\end{tabular} & \begin{tabular}{|l|}
$\mathrm{M}$ \\
$\mathrm{G}$ \\
$\mathrm{M}$
\end{tabular} & & & & & & & $\begin{array}{l}\mathrm{P} \\
\mathrm{P}\end{array}$ & 2 & & & 1 & $\mathrm{P}$ & & & 2 & $P$ & & & & & & 1 & $\begin{array}{l}300 \\
300 \\
300\end{array}$ \\
\hline
\end{tabular}

Notes: Taxa present in a sample but not recorded in the count of 300 are listed in this table with a "P". Abundance: $A=$ abundant, $C=$ common, $F=$ few, $R=$ rare, $B=$ barren. Preservation: $\mathrm{G}=$ good, $\mathrm{M}=$ moderate, $\mathrm{P}=$ poor. 
same problems with barren intervals and sparse, non-age-diagnostic assemblages as were found on DSDP Leg 38 (e.g., Donnally, 1989; Spiegler and Jansen, 1989). Agglutinated benthic foraminifer assemblages occur in Leg 104 sites, but with only broad stratigraphic control (Osterman and Qvale, 1989). Manum et al. (1989) also had problems in correlating their assemblages with those reported by Manum (1976) in other sites drilled in the same basin. Magnetic reversal stratigraphy of the non-volcanic Paleogene sequence at Sites 642 and 643 is poor to absent (Eldholm, Thiede, Taylor, et al., 1987).

Damassa et al. (1990) reported initial results of biostratigraphically useful dinocysts in Paleogene sediments from numerous North Atlantic and Norwegian-Greenland Sea DSDP sites. They did not include complete range charts, but only listed ranges and datums of selected species that appear to be correlative across this wide geographic region. Their age correlations were made with the published calcareous nannoplankton biostratigraphy of each site. Although they included material from three Norwegian-Greenland Sea DSDP sites (Sites 336, 338, and 345), their age calibrations still suffer the limitation that nannofossils are more scarce and sporadic in these northern areas than in the North Atlantic basin.

Goll (1989) synthesized the various microfossil biostratigraphies of the Paleogene interval from ODP Leg 104 Sites 642 and 643, making comparisons to previous biostratigraphic studies from DSDP Leg 38. He revised the age assignments for Sites 642 and 643, based largely on compromises between benthic foraminiferal data and the dinoflagellate biostratigraphy of Manum et al. (1989). His interpretation assigned the Chiropteridium lobospinosum zone of Manum et al. (1989) to the upper Eocene instead of the lower Oligocene, and placed much of the Adnatosphaeridium vitattum zone of Manum et al. (1989) in the lower Eocene rather than the middle Eocene.

\section{Dinocyst Biostratigraphy of Hole 913B}

Hole 913B presents another site where correlation to refined calcareous plankton zonations is not possible, and where good magnetostratigraphic control is not available. The biosiliceous-rich interval of Hole 913B provides a potential correlation of dinocysts to diatoms, silicoflagellates, and radiolarians; however, the zonations and correlations of these other groups are also in development (see Hull, this volume, and Scherer and Koç, this volume). Thus, the resolution with which we can age-date these high-latitude Paleogene sediments and the certainty with which we can correlate them to other deep-sea basins worldwide will likely remain somewhat low, until we recover more sections that can provide good paleomagnetic reversal stratigraphies. Below, I will discuss the lowest occurrence datums of dinocysts first, and their implications for subdividing the section. Then I will discuss highest occurrence datums that may be relatively reliable. In discussing the latter, I assume that potential reworking of middle Eocene or younger dinocysts may have occurred in Hole $913 \mathrm{~B}$, along with the more easily recognized lower Eocene and older reworked taxa. Therefore, both highest and lowest occurrences, as well as comparisons with other microfossil groups, will all be considered in determining the age of the section.

\section{Lowest Occurrences}

The base of the studied interval, in Sample 151-913B-36R-3, 103-105 cm, contains Cerebrocysta bartonensis, which has a reported lowest occurrence in the upper middle Eocene (Bartonian; Bujak et al., 1980), although Powell (1992) questionably extends its range into the Lutetian. Just above this, in Sample 913B-35R-2, 103-105 $\mathrm{cm}$, are the lowest occurrences of Corrudinium incompositum and Heteraulacacysta porosa. The lowest reported occurrences of $C$. incompositum are in the middle Eocene (see Head and Norris, 1989, for detailed discussion), whereas the lowest occurrence of $H$. porosa is in the upper middle Eocene (Bartonian; Bujak et al., 1980, Williams and Bujak, 1985). Thus, the base of the studied interval (Sample 913B-36R-3, 103-105 cm) is no older than upper middle Eocene (Bartonian).

Separation of the middle and upper Eocene based on lowest occurrences is difficult in this hole, since the markers used in various zonation schemes are either rare or absent, or they are based instead on highest occurrences. Manum (1976) shows the range of Enneadocysta arcuata as no older than late Eocene in Site 338, but Manum et al. (1989) record this species in the middle Eocene at Site 643. Therefore, this taxon is not useful for distinguishing the middle and upper Eocene in Hole 913B.

Damassa et al. (1990) record the restricted range of Cribroperidinium sp. 2 within the upper Eocene of many North Atlantic and Norwegian-Greenland Sea DSDP sites. This species, characterized by a large reticulate ornamentation on the periphragm, ranges from Sample 913B-33R-2, 100-104 cm, to $23 \mathrm{R}-1,98-102 \mathrm{~cm}$, which would suggest that this interval may be assigned to the upper Eocene.

Svalbardella cooksoniae has an upper Eocene to lower Oligocene range, according to Powell (1992). This is consistent with its reported range in the Labrador Sea (Head and Norris, 1989). In Hole 913B, this species occurs sporadically down to Sample 913B-34R-2, 103$105 \mathrm{~cm}$, which suggests that upper Eocene sediments may occur down to this level.

Chiropteridium galea is reported to have a lowest occurrence in the upper Eocene (Damassa et al., 1990, as C. mespilanum; and Williams and Bujak, 1985, as C. dispersum). This species, however, only occurs in Sample 913B-20R-2, 98-102 cm, along with Oligocene taxa (see below); thus, it cannot be used to distinguish the middle and upper Eocene in Hole 913B.

Phthanoperidinium filigranum was described by Benedek (1972) from the Oligocene of Germany, and it has not been reported elsewhere older than Oligocene. Its presence in Sample 913B-36R-3, $103-105 \mathrm{~cm}$, may be considered to be an extension of its range.

Wetzeliella gochtii occurs in Sample 913B-20R-2, 98-102 cm. Its lowest occurrence is commonly used to recognize the lower Oligocene (Williams and Bujak, 1985). Rare occurrences of this species below this sample in Hole 913B are questionably identified.

Phthanoperidinium amoenum is considered by Williams and Bujak (1985) to have a lowest occurrence in the lower Oligocene, however Manum (1976) reported this taxon in the upper Eocene at Site 338. Therefore, it cannot be used to distinguish the upper Eocene and Oligocene in this hole. Sample 913B-20R-2, 98-102 cm, contains Reticulatosphaera actinocoronata and Chiropteridium lobospinosum. These two species are generally considered not to range below the Oligocene (Powell, 1992; Williams et al., 1993; Williams and Bujak, 1985; Haq et al., 1987), although Head and Norris (1989) record $R$. actinocoronata in the uppermost Eocene at Site 647, and Brinkhuis and Biffi (1993) report it in the uppermost Eocene of central Italy. The presence of $C$. lobospinosum, however, indicates that this sample is no older than Oligocene. The rare, isolated occurrence of Areosphaeridium diktyoplokus in this same sample is considered to be reworked. On the basis of lowest occurrences of dinocyst ranges, therefore, the boundary between the upper Eocene and Oligocene in Hole 913B is below Sample 913B-20R-2, 98-102 cm.

\section{Highest Occurrences}

A single occurrence of Araneosphaera araneosa in Sample 913B$33 \mathrm{R}-2,100-104 \mathrm{~cm}$, suggests that this sample may be no younger than middle Eocene (Bujak et al., 1980; Köthe, 1990; although Williams and Bujak [1985] record its range into the upper Eocene).

Cerebrocysta bartonensis is reported to have a range restricted to the middle Eocene (Bujak et al., 1980; Powell, 1992) but it ranges up to Sample $913 \mathrm{~B}-24 \mathrm{R}-4,68-70 \mathrm{~cm}$, in this study. Although specimens comparable to the type material of Bujak (in Bujak et al., 1980) occur in Hole 913B, I have also included within my concept forms with 
some variation in the degree of reticulation, that show morphologies closer to Corrudinium incompositum (see Head and Norris, 1989, for discussion on variations in reticulation and granulation of $C$. incompositum). Because of my broader taxonomic concept, the range of $C$. bartonensis may be artificially extended above that of the forms recorded by Bujak. On the other hand, reworking of this taxon may have occurred.

Fibrocysta axialis occurs sparsely and sporadically in the lower half of the study section, up to Sample 913B-29R-2, 99-102 cm. The range of this taxon is questionable, as there are some large discrepancies reported in the literature. Damassa et al. (1990) report $F$. axialis in the upper Paleocene to lower Eocene of several DSDP sites, which by comparison would suggest that it is reworked in Hole 913B. On the other hand, Williams et al. (1993) report its range from upper Eocene to lower Oligocene. Different species concepts may be the cause of these discrepancies.

Heteraulacacysta porosa is reported by Bujak et al. (1980) and Powell (1992) as having a narrow stratigraphic range within the Bartonian (upper middle Eocene). Williams and Bujak (1985) report its range to be restricted to the equivalent of middle Eocene calcareous nannofossil zone NP16. Consequently, Manum et al. (1989) suggested that the occurrence of $H$. porosa was evidence for the lack of any recognizable upper Eocene sediments at Site 643. However, Damassa et al. (1990) and Head and Norris (1989) both report H. porosa in upper Eocene sediments, based on the correlation to calcareous nannofossil zonations. Therefore, its range up to Sample 913B-25R$2,110-113 \mathrm{~cm}$, does not necessarily indicate that middle Eocene strata occur up to this level within Hole 913B, nor does it necessarily indicate that this taxon has been reworked.

Phthanoperidinium geminatum ranges up to Sample 913B-29R-1, 99-102 cm, and has two abundance peaks in Samples 913B-35R-2, 103-105 cm (almost a monospecific assemblage), and 32R-2, 104$107 \mathrm{~cm}$. According to Williams and Bujak (1985), this taxon has its highest occurrence at the top of the middle Eocene. Manum et al. (1989) also record this species from the middle Eocene, and show an abundance peak at the top of its range at Site 643. An abundance peak of this species has also been observed at Site 338, Core 27 (S. Damassa, pers. comm., 1995), which is late Eocene in age (Manum, 1976; Martini and Müller, 1976). The presence of this species may indicate possible middle Eocene sediments up to Sample 913B-29R-1, 99$102 \mathrm{~cm}$. The presence of a pronounced abundance peak at three different sites within the Norwegian-Greenland Sea basin may provide an additional tool for correlation. However, because at least two abundance peaks were observed in Hole 913B (Table 1), more closely spaced sampling at all sites would be necessary before more certain stratigraphic correlations could be made.

Phthanoperidinium distinctum and Phthanoperidinium powellii were described by Bujak (1994) from the North Sea, and their highest occurrences were used by Bujak and Mudge (1994) as zonal markers in the middle Eocene (Lutetian). Phthanoperidinium distinctum is quite common in a few samples and has a consistent range up to Sample 913B-29R-2, 99-102 cm, with rare sporadic occurrences above this sample. On the other hand, $P$. powellii is rare and sporadic through the section (Table 1). Because of the common, consistent range of $P$. distinctum in Hole 913B, I believe that its occurrence is largely in situ rather than reworked. Its highest consistent occurrence in Sample 913B-29R-2, 99-102 cm, may, along with the other species discussed above, indicate middle Eocene sediments up to this level, although based on the presence of $C$. bartonensis and H.poro$s a$, it could not be older than Bartonian. Therefore, $P$. distinctum and $P$. powellii have range extensions above those reported in the North Sea by Bujak and Mudge (1994).

Rottnestia borussica has a highest occurrence in Sample 913B29R-1, 99-102 cm. Bujak and Mudge (1994) report this species' highest occurrence in the North Sea near the top of the middle Eocene (Bartonian). Williams and Bujak (1985) and Powell (1992) also report its highest occurrence at the top of the middle Eocene. Brinkhuis and Biffi (1993), however, report its range into the lower Oligocene in central Italy. This may be due to a latitudinal variation in its range. If higher latitude occurrences are relied upon, its occurrence in Hole 913B suggests possible middle Eocene up to Sample 913B-29R-1, 99-102 cm.

The Eocene/Oligocene boundary stratotype has been defined by the highest occurrence of the hantkeninids (planktonic foraminifers), which means that no dinoflagellate datums correspond to the exact placement of the boundary (see discussion in Brinkhuis and Biffi, 1993). In general, palynologists still use a few datums to approximate the boundary, just as calcareous nannofossil workers also approximate the boundary on the basis of the highest occurrence of Discoaster saipanensis and/or Discoaster barbadiensis. The dinocyst datums most commonly used are the highest occurrences of Areosphaeridium diktyoplokus, Cordosphaeridium funiculatum, and Batiacasphaera compta (see Williams and Bujak, 1985; Brinkhuis and Biffi, 1993 ) as well as the lowest occurrences of $R$. actinocoronata, W. gochtii, and $P$. amoenum (see discussion above). In Hole 913B, A. diktyoplokus and C. funiculatum occur up to Sample 913B-24R-2, $77-79 \mathrm{~cm}$, whereas $B$. compta ranges slightly higher, to Sample 913B-24R-1, 68-70 cm. Based on the common palynological approximation of the Eocene/Oligocene boundary, I interpret this boundary to be approximately above Sample 913B-24R-2, 77-79 $\mathrm{cm}$. Because there are no planktonic foraminifers present in this part of Hole 913B, an exact placement of the boundary is impossible. Other microfossil groups seem to indicate the location of this boundary somewhere within Core 913B-24R (see Hull, this volume, Scherer and Koç, this volume, and Locker, this volume), which is close to where the dinocyst evidence suggests. Another species, Areosphaeridium michoudii, also has its highest occurrence in Sample 913B-24R-2, 77-79 $\mathrm{cm}$. This species is reported by Bujak and Mudge (1994) to have a highest occurrence slightly lower in the upper Eocene than $A$. diktyoplokus in the North Sea. Areosphaeridium michoudii has not yet been reported in other localities, thus its total stratigraphic range, along with geographic variations in range, is yet to be worked out.

\section{Comparison with Other Microfossil Groups}

Shipboard diatom and silicoflagellate biostratigraphy suggested an age of earliest Oligocene to late Eocene for Cores 913B-24R through 29R (), and an age of middle Eocene for Core 913B-32R (Myhre, Thiede, Firth, et al., 1995). Cores 913B-30R, 31R, and 33R and below were barren of diatoms and silicoflagellates. Radiolarian assemblages (Hull, this volume) suggest an age of earliest Oligocene to late Eocene from Core 913B-23R to Section 913B-24R-4. From Section $913 B-24 R-5$ to $29 R-4$, radiolarians suggest a middle to late Eocene age, but are more likely late Eocene, based on similarities to DSDP Site 339 . From Core $30 \mathrm{R}$ to $31 \mathrm{R}$, radiolarians indicate an age of middle to early late Eocene, and from Section 31R-CC to Section $32 \mathrm{R}-2$, radiolarians indicate a middle Eocene age.

\section{Biostratigraphic Summary}

Based on the events discussed above and comparison with other microfossil groups, the boundary between the upper middle Eocene and upper Eocene is located somewhere between Samples 913B$33 \mathrm{R}-2,100-104 \mathrm{~cm}$, and 29R-1, 99-102 cm (Fig. 2). Several taxa with highest occurrences in the middle Eocene have their highest occurrences within this interval, whereas a couple of other dinocysts that appear to be limited to the upper Eocene or younger (albeit with scant records for comparison) have their lowest occurrences within this same interval. Siliceous microfossils indicate a middle Eocene age for at least Cores $913 \mathrm{~B}-31 \mathrm{R}$ and $32 \mathrm{R}$, which suggests that there may not be significant reworking of middle Eocene dinocysts in this hole. However, I choose to remain somewhat conservative and not try to pick a single horizon to delineate the middle and upper Eocene. 


\section{Depth (mbsf)}

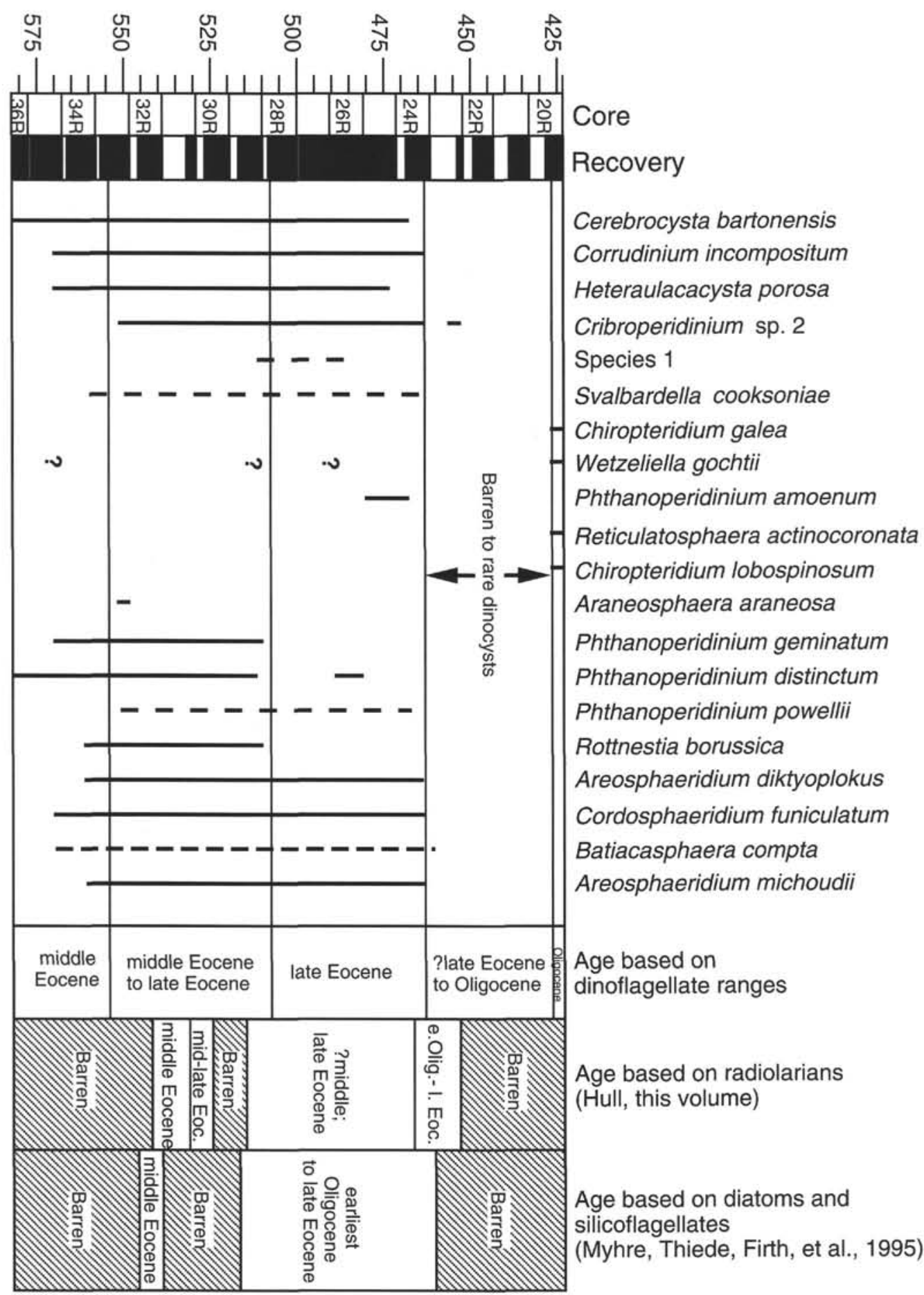

Figure 2. Summary of ranges of selected stratigraphically useful dinoflagellate cyst species in Hole 913B, age of the studied section based on these taxa, and comparative age assignments based on radiolarians (Hull, this volume), and diatoms and silicoflagellates (Myhre, Thiede, Firth, et al., 1995).

The top of the Eocene is placed above Sample 913B-24R-2, 77-79 $\mathrm{cm}$. The species $A$. diktyoplokus ranges into the lowest Oligocene, based on comparison with the extinction of the hantkeninids in Italy (Brinkhuis and Biffi, 1993; Brinkhuis, 1994). Therefore, its highest occurrence in Hole 913B may be slightly higher than the "true" Eocene/Oligocene boundary. However, because the planktonic fora- minifers are absent in this interval, my placement should be considered the palynologic approximation of the top of the Eocene. Between Samples 913B-24R-2, 77-79 cm, and 20R-2, 98-102 cm, is an interval with rare or no dinocysts. Taxa that are obviously reworked make up a larger relative percentage of the sparse microflora, and preservation is moderate to poor within this interval. This almost bar- 
ren interval may have artificially truncated the ranges of taxa such as A. diktyoplokus and $C$. funiculatum. Because of the lack of age diagnostic taxa within this interval, it is assigned an age of ?late Eocene to early Oligocene. Sample 913B-20R-2, 98-102 cm, is assigned an age of early Oligocene based on the occurrence of $C$. lobospinosum.

\section{Dinocyst Assemblage Changes}

Relative abundance counts of selected taxa, as well as unidentified taxa and reworked taxa, plus percent abundances of diatoms, radiolarians, total organic carbon (TOC), and $\mathrm{C} / \mathrm{N}$ ratios are plotted in Figure 3. To display relative abundance fluctuations of different taxa, species were grouped into genera, and some genera with morphological affinities were also grouped together (e.g., Areoligera and Glaphyrocysta; Spiniferites and Achomosphaera; etc.). Only those genera or groups of genera that composed a significant percentage of the total assemblage were plotted in Figure 3.

It is important, when interpreting these plots, to note that above Sample 913B-24R-2, 77-79 cm (464.27 mbsf), most samples have very few dinocysts (Table 1), thus the relative abundances of the different categories in this interval (except for Sample 913B-20R-2, 98$102 \mathrm{~cm} ; 425.98 \mathrm{mbsf}$; with a count of 300 specimens) have a high degree of uncertainty and should be ignored.

High relative abundances of unidentified taxa occur between 464 and $425 \mathrm{mbsf}$, owing to the poorer preservation in this interval. High relative abundances of reworked taxa in the same interval may be explained by the large decrease of in situ dinocysts. The overall number of reworked specimens may actually be relatively constant throughout the section, but they are flooded by a large amount of in situ dinocysts below $464 \mathrm{mbsf}$, which makes them appear to be much less abundant than above 464 mbsf.

Recent work has shown that information on paleoproductivity and upwelling systems can be gained by examining the peridinioid vs. gonyaulacoid components of dinocyst assemblages. Peridinioid dinocysts are considered to represent largely heterotrophic dinoflagellates whose abundances have been linked to diatom blooms (e.g., Bujak, 1984; Lewis et al., 1990; Eshet et al., 1994). Eshet et al. (1994) linked their dinocyst paleoproductivity index to a foraminiferal paleoproductivity index, and concluded that high ratios of peridinioid to gonyaulacoid dinocysts may indicate high paleoproductivity episodes even if biosiliceous phytoplankton are not preserved in the sediments. Dale and Fjellså (1994) presented a detailed analysis of the use of dinocyst assemblages for evaluating paleoproductivity. Some of their main points were: (1) dinocysts in deep-sea sediments are largely transported from coastal and neritic environments and thus may not directly reflect upwelling conditions in the deep sea; (2) it is heterotrophic dinoflagellates, not necessarily all peridinioid dinoflagellates, that reflect upwelling conditions, and these two categories are not completely equivalent (i.e., some peridinioid dinoflagellates are autotrophic); (3) heterotrophic dinoflagellates occur in abundance in places other than upwelling regions, such as sea-ice dominated areas; (4) uncertainties in taxonomy and biological affinity of pre-Neogene dinocysts make it difficult to determine which ones represent heterotrophic species. Given this uncertainty, however, the abundances of peridinioid dinocyst taxa may be the best approximation for distinguishing heterotrophic dinoflagellates in ancient rocks.

Duffield and Stein (1986), however, document Miocene dinocyst assemblages dominated by protoperidiniacean cysts in a shelf environment with high terrestrial organic matter influx from a nearby paleo-delta. They interpreted the high protoperidiniacean abundances not as upwelling and primary productivity indicators, but as indicators of high terrestrially derived nutrient levels. Brinkhuis et al., (1992) also suggested that large abundances of Deflandrea spp. in the Oligocene/Miocene transition in Italy may be linked to some type of sea-level fluctuation in a neritic environment, whereby nutrient levels become higher, owing either to turbulent mixing of shelf sediments during a rapid transgression or to increased river input during a sealevel lowstand. Brinkhuis et al. (1992) stated that the extinct genus Deflandrea may be considered to represent a probable heterotrophic dinoflagellate group, based on morphological similarities to the protoperidiniacean dinoflagellates.

In Hole 913B, large fluctuations occur in the percentages of peridinioid (mostly Phthanoperidinium spp. and Deflandrea spp.) and gonyaulacoid (mostly Spiniferites spp. and Operculodinium spp.) dinocysts. In a restricted interval between 424 and 500 mbsf, the sediments are composed largely of biosiliceous ooze, with fluctuations in abundances of diatoms and radiolarians (Fig. 3). In this same interval, two large peaks in the relative abundance of Phthanoperidinium and Deflandrea occur. Shipboard organic geochemistry analyses (Myhre, Thiede, Firth, et al., 1995) also reported high total organic carbon (TOC) content and low $\mathrm{C} / \mathrm{N}$ ratios in this interval (Fig. 3), which indicate large amounts of marine organic matter in the sediment. This coincidence of high abundance peaks of peridinioid dinocysts with high abundances of diatoms is similar to those found elsewhere, and this may be considered as further evidence to support the interpretation of high relative abundances of certain peridinioid dinocysts as an index for high paleoproductivity.

Two more high relative abundance peaks of Phthanoperidinium occur, centered at 541 mbsf (Core 913B-32R) and 570 mbsf (Core 913B-35R). The peak at 541 mbsf coincides with a peak in TOC of $1.97 \%$, whereas the peak at $570 \mathrm{mbsf}$ coincides with a smaller TOC peak of $0.56 \%$ (Myhre, Thiede, Firth, et al., 1995). The $\mathrm{C} / \mathrm{N}$ ratios at these levels are 14.1 at $541 \mathrm{mbsf}$ and 9.3 at $571 \mathrm{mbsf}$ (Fig. 3). C/N ratios $>10$ may indicate significant amounts of terrestrial organic matter (see discussion in Myhre, Thiede, Firth, et al., 1995). Biosilica is largely absent between 500 and 540 mbsf, but a significant amount of pyritized diatoms occur in discrete layers through this interval, and especially in Core 913B-32R (538.8-548.4 mbsf), where they are well preserved enough to identify for biostratigraphic age assignments (Scherer and Koç, this volume; Myhre, Thiede, Firth, et al., 1995). Scherer and Koç (this volume) state that the discrete layers containing diatoms are usually green, laminated layers, and may represent productivity events. In addition, well-preserved pyritized radiolarians are also present in Cores 913B-31R and 32R (between 538.5 and 542.5 mbsf; Hull, this volume). Pyritized silicoflagellates and ebridians also occur in Core 913B-32R (Myhre, Thiede, Firth, et al., 1995). Poorly preserved, pyritized fragments of all of these siliceous microfossils occur lower in the hole, especially diatoms in Samples 913B-35R-5, $135 \mathrm{~cm}$ (575 mbsf), 42R-3, $119 \mathrm{~cm}$ (639.5 mbsf), and 45R-CC (674 mbsf; Myhre, Thiede, Firth, et al., 1995). Based on a cursory analysis of other samples not listed in Table 1, the P. geminatum acme at 570 mbsf continues downhole to between 574 and 576 mbsf.

At Site 338, Section 27R-2, an abundance peak of Phthanoperidinium geminatum occurs, similar to that at 541 and 570 mbsf in Hole 913B (S. Damassa, pers. comm., 1995). This section at Site 338 also consists of a diatom-rich biosiliceous ooze. At Site 643 (Manum et al., 1989), a peak abundance of $P$. geminatum occurs in a mudstone with little or no biosilica content. The near absence of biosilica in the lower parts of the section in Hole 913B, where dinocysts may indicate possible high paleoproductivity events, may be due to several factors: either biosilica production was low or absent, or biosilica was corroded before deposition in the sediments, or biosilica was diagenetically altered after deposition in the sediments, or combinations of all three. Detailed discussions of these different processes is beyond the scope of this paper; however, evidence for post-depositional diagenesis of biosilica is reported in one other high-latitude EoceneOligocene section, Site 647 in the Labrador Sea (Bohrmann and Thiede, 1989). Bohrmann and Stein (1989) also determined that high amounts of primary biogenic silica had been deposited in upper Eocene sediments at Site 647, although they have been subsequently 

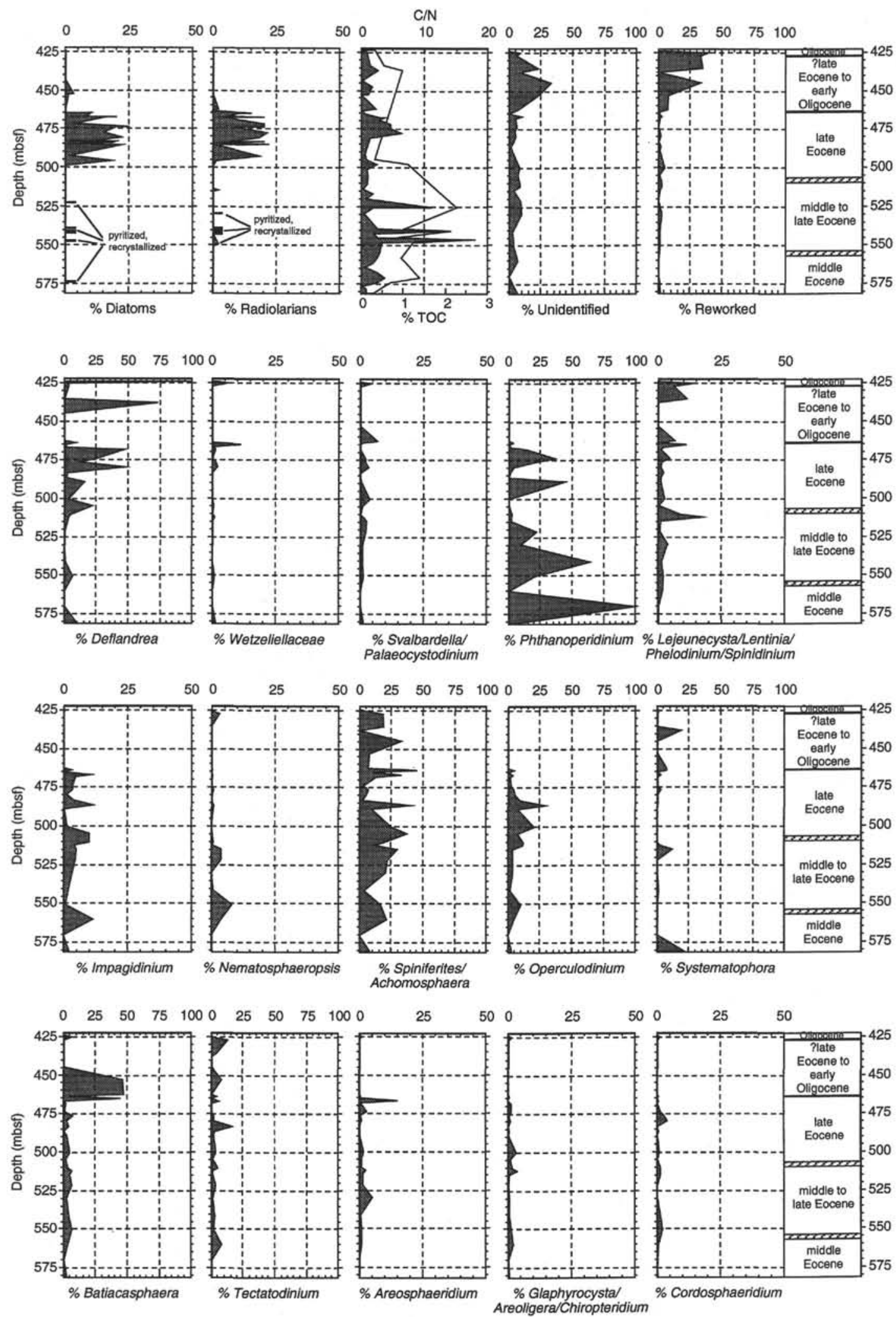

Figure 3. Percent abundances of numerically significant dinocyst genera and groups of genera, unidentified cysts, and reworked dinocysts in Hole 913B, based on counts of up to 300 specimens per sample. Percent abundances of diatoms and radiolarians come from smear slide estimates (Myhre, Thiede, Firth, et al., 1995). Scattered occurrences of pyritized diatom and radiolarian fragments are marked with thick lines (based on data from Myhre, Thiede, Firth, et al., 1995; Hull, this volume; and Scherer and Koç, this volume). Percent TOC (shaded area) and C/N ratios (light line) come from shipboard geochemical data (Myhre, Thiede, Firth, et al., 1995). The interval between 424 and 464 mbsf contains rare to no dinocysts; thus, the percent abundances of the various dinocyst groups in this interval are not comparable with the rest of the section. 
altered to opal-CT. The presence of pyritized fragments of siliceous microfossils in discrete layers below 500 mbsf in Hole 913B indicates that some biosilica was deposited, but underwent post-depositional diagenesis. The relative abundance peaks of Phthanoperidinium and Deflandrea, which may represent heterotrophic dinoflagellates, show a strong correspondence with biosiliceous-rich sediments in Hole 913B, and possible correspondence with discrete pyritized biosilica layers at about 541 and $570 \mathrm{mbsf}$. This correspondence suggests that acmes in these two genera in Hole 913B are records of high paleoproductivity events, possibly caused by upwelling. Because of the high amounts of terrestrial organic matter at this site, however, the influence of terrestrially derived nutrients on these acmes, as suggested by Brinkhuis et al. (1992), cannot be entirely ruled out. A closer analysis of these acmes in sites throughout the Norwegian-Greenland Sea is necessary to clarify their relationships with paleoceanographic or other events.

Because of the scarcity of in situ dinocysts above $464 \mathrm{mbsf}$, it is not possible to assess the assemblage changes that may have occurred across the Eocene/Oligocene boundary. Of the non-reworked dinocysts in Sample 913B-20R-2, 98-102 cm (Oligocene), peridinioid dinocysts are slightly more abundant than gonyaulacoid dinocysts (Table 1).

\section{CONCLUSIONS}

1. Dinocyst assemblages in the Eocene to Oligocene interval of Hole 913B are extremely diverse. One significant component of these diverse assemblages is reworked Cretaceous, Paleocene, and lower Eocene taxa. Outcropping strata representing these stratigraphic intervals occur along the northeastern coast of Greenland, about $400 \mathrm{~km}$ west of Site 913 (Escher and Pulvertaft, 1995) and provide likely sources of the reworked palynomorphs (Nøhr-Hansen, 1993).

2. Based on comparison with reported ranges of dinocysts from other localities both within and without the Norwegian-Greenland Sea, the studied interval between 424 and 581 mbsf may be subdivided as follows:

a. The interval from 581.42 to $560.68 \mathrm{mbsf}$, in the absence of any exclusively upper Eocene taxa, is assigned to the upper middle Eocene (Bartonian).

b. Several middle Eocene taxa have their highest occurrences between 550.90 and 510.89 mbsf, whereas a couple of taxa that may be restricted to the upper Eocene or younger have their lowest occurrences in this same interval. Therefore this interval is assigned to the upper middle Eocene to upper Eocene.

c. The interval from 505.15 to 464.27 mbsf lies above all exclusively middle Eocene taxa and contains a couple of upper Eocene taxa, and is assigned to the upper Eocene.

d. The interval from 462.68 to 427.45 mbsf contains only rare in situ taxa that are not age diagnostic. Therefore, it is assigned to the ?upper Eocene to lower Oligocene.

e. The interval from 425.98 to 424.49 mbsf contains a couple of Oligocene marker taxa, and is assigned to the Oligocene.

3. The dinocyst assemblages from the upper middle Eocene to the Oligocene contain relative abundance peaks of the peridinioid genera Deflandrea and Phthanoperidinium. Previous work has linked high peridinioid abundances to high paleoproductivity zones often characterized by diatom oozes. In the interval from 464 to $500 \mathrm{mbsf}$, two abundance peaks of these genera co-occur with biosiliceous-rich oozes with high diatom and radiolarian content. Using the abundance peaks of these genera as an index for high paleoproductivity indicates that other peak paleoproductivity episodes may have occurred earlier than the late Eocene-early Oligocene biosiliceous-rich event in Hole 913B, even though the primary biosilica may not have been preserved within the older sediments. Two other potential peaks in paleoproductivity occur at about 541 and 570 mbsf.

\section{ACKNOWLEDGMENTS}

Reviews from Svein Manum and Jens Matthiessen were very helpful in improving this paper. Discussions with Sarah Damassa were also invaluable for sorting out some of the taxonomy, and making sense of the data. The instructors of the Paleogene Dinoflagellate Short Course in Utrecht, The Netherlands, in June 1994 (Graham Williams, Sarah Damassa, Jonathon Bujak, and Henk Brinkhuis) are commended for giving me a great head start on this project by sharing their expertise. This project was supported by a USSAC grant.

\section{REFERENCES}

Benedek, P.N., 1972. Phytoplankton aus dem Mittel- und Oberoligozän von Tönisberg (Niederrheingebiet). Palaeontographica B, 137:1-71.

Bjørklund, K.R., 1976. Radiolaria from the Norwegian Sea, Leg 38 of the Deep Sea Drilling Project. In Talwani, M., Udintsev, G., et al., Init. Repts. DSDP, 38: Washington (U.S. Govt. Printing Office), 1101-1168.

Bohrmann, G., and Stein, R., 1989. Biogenic silica at ODP Site 647 in the southern Labrador Sea: occurrence, diagenesis, and paleoceanographic implications. In Srivastava, S.P., Arthur, M.A., Clement, B., et al., Proc. ODP, Sci. Results, 105: College Station, TX (Ocean Drilling Program), $155-170$.

Bohrmann, G., and Thiede, J., 1989. Diagenesis in Eocene claystones, ODP Site 647, Labrador Sea: formation of complex authigenic carbonates, smectites, and apatite. In Srivastava, S.P., Arthur, M.A., Clement, B., et al., Proc. ODP, Sci. Results, 105: College Station, TX (Ocean Drilling Program), 137-154.

Brinkhuis, H., 1994. Late Eocene to early Oligocene dinoflagellate cysts from the Priabonian type-area (Northeast Italy): biostratigraphy and paleoenvironmental interpretation. Palaeogeogr., Palaeoclimatol., Palaeoecol., 107:121-163.

Brinkhuis, H., and Biffi, U., 1993. Dinoflagellate cyst stratigraphy of the Eocene/Oligocene transition in central Italy. Mar. Micropaleontol., 22:131-183.

Brinkhuis, H., Powell, A.J., and Zevenboom, D., 1992. High-resolution dinoflagellate cyst stratigraphy of the Oligocene/Miocene transition interval in north-west and central Italy. In Head, M.J., and Wrenn, J.H. (Eds.), Neogene and Quaternary Dinoflagellate Cysts and Acritarchs. Am. Assoc. Stratigr. Palynol. Found., 219-258.

Bujak, J., and Mudge, D., 1994. A high-resolution North Sea Eocene dinocyst zonation. J. Geol. Soc. London, 151:449-462.

Bujak, J.P., 1984. Cenozoic dinoflagellate cysts and acritarchs from the Bering Sea and northern North Pacific, Deep Sea Drilling Project, Leg 19. Micropaleontology, 30:180-212.

, 1994. New dinocyst taxa from the Eocene of the North Sea. $J$. Micropalaeontol, 13:119-131.

Bujak, J.P., Downie, D., Eaton, G.L., and Williams, G.L., 1980. Dinoflagellate cysts and acritarchs from the Eocene of southern England. Spec. Pap. Paleontol., 24:1-100.

Cande, S.C., and Kent, D.V., 1992. A new geomagnetic polarity time scale for the Late Cretaceous and Cenozoic. J. Geophys. Res., 97:1391713951.

Costa, L., and Downie, C., 1979. Cenozoic dynocyst stratigraphy of Sites 403 to 406 (Rockall Plateau) IPOD, Leg 48. In Montadert, L., Roberts, D.G., et al., Init. Repts. DSDP, 48: Washington (U.S. Govt. Printing Office), 513-529.

Dale, B., and Fjellså, A., 1994. Dinoflagellate cysts as paleoproductivity indicators: state of the art, potential, and limits. In Zahn, R., Pedersen, T.F., Kaminski, M.A., and Labeyrie, L. (Eds.), Carbon Cycling in the Glacial Ocean: Constraints on the Ocean's Role in Global Change: Berlin (Springer), NATO ASI Ser. I, 521-537.

Damassa, S.P., Goodman, D.K., Kidson, E.J., and Williams, G.L., 1990. Correlation of Paleogene dinoflagellate assemblages to standard nannofossil zonation in North Atlantic DSDP sites. Rev. Paleobot. Palynol., 65:331339. 
De Coninck, J., 1986. Organic walled phytoplankton from the Bartonian and Eo-Oligocene transitional deposits of the Woensdrecht borehole, southern Netherlands. Meded. Rijks Geol. Dienst, 40-2:1-49.

Donnally, D.M., 1989. Calcareous nannofossils of the Norwegian-Greenland Sea: ODP Leg 104. In Eldholm, O., Thiede, J., Taylor, E., et al., Proc. ODP, Sci. Results, 104: College Station, TX (Ocean Drilling Program), 459-486.

Duffield, S.L., and Stein, J.A., 1986. Peridiniacean-dominated dinoflagellate cyst assemblages from the Miocene of the Gulf of Mexico shelf, offshore Louisiana. In Wrenn, J.H., Duffield, S.L., Stein, J.A. (Eds.), Papers from the First Symposium on Neogene Dinoflagellate Cyst Biostratigraphy. AASP Contrib. Ser., 17: 27-45.

Eldholm, O., Thiede, J., Taylor, E., et al., 1987. Proc. ODP, Init. Repts., 104: College Station, TX (Ocean Drilling Program).

, 1989. Proc. ODP, Sci. Results, 104: College Station, TX (Ocean Drilling Program).

Escher, J.C., and Pulvertaft, T.C.R., 1995. Geological Map of Greenland [scale 1:2,500,000]. Geol. Surv. Greenl.

Eshet, Y., Almogi-Labin, A., and Bein, A., 1994. Dinoflagellate cysts, paleoproductivity and upwelling systems: a Late Cretaceous example from Israel. Mar. Micropaleontol., 23:231-240.

Fensome, R.A., Taylor, F.J.R., Norris, G., Sarjeant, W.A.S., Wharton, D.L., and Williams, G.L., 1993. A classification of living and fossil dinoflagellates. Micropaleontol., Spec. Publ., 7.

Goll, R.M., 1989. A synthesis of Norwegian Sea biostratigraphies: ODP Leg 104 on the Vøring Plateau. In Eldholm, O., Thiede, J., Taylor, E., et al., Proc. ODP, Sci. Results, 104: College Station, TX (Ocean Drilling Program), 777-826.

Haq, B.U., Hardenbol, J., and Vail, P.R., 1987. Chronology of fluctuating sea levels since the Triassic. Science, 235:1156-1167.

Head, M.J., and Norris, G., 1989. Palynology and dinocyst stratigraphy of the Eocene and Oligocene in ODP Leg 105, Hole 647A, Labrador Sea. In Srivastava, S.P., Arthur, M.A., Clement, B., et al., Proc. ODP, Sci. Results, 105: College Station, TX (Ocean Drilling Program), 515-550.

Köthe, A., 1990. Paleogene dinoflagellates from Northwest Germany: biostratigraphy and paleoenvironment. Geol. Jahrb., Reihe A, 118:3-111.

Lentin, J.K., and Williams, G.L., 1993. Fossil dinoflagellates: index to genera and species. Am. Assoc. Stratigr. Palynol. Contrib. Ser., 28.

Lewis, J., Dodge, J.D., and Powell, A.J., 1990. Quaternary dinoflagellate cysts from the upwelling system offshore Peru, Hole 686B, ODP Leg 112. In Suess, E., von Huene, R., et al., Proc. ODP, Sci. Results, 112: College Station, TX (Ocean Drilling Program), 323-328.

Manum, S.B., 1976. Dinocysts in Tertiary Norwegian-Greenland Sea sediments (Deep Sea Drilling Project Leg 38), with observations on palynomorphs and palynodebris in relation to environment. In Talwani, M., Udintsev, G., et al., Init. Repts. DSDP, 38: Washington (U.S. Govt. Printing Office), 897-919.

Manum, S.B., Boulter, M.C., Gunnarsdottir, H., Rangnes, K., and Scholze, A., 1989. Eocene to Miocene palynology of the Norwegian Sea (ODP
Leg 104). In Eldholm, O., Thiede, J., Taylor, E., et al., Proc. ODP, Sci. Results, 104: College Station, TX (Ocean Drilling Program), 611-662.

Martini, E., and Müller, C., 1976. Eocene to Pleistocene silicoflagellates from the Norwegian-Greenland Sea (DSDP Leg 38). In Talwani, M., Udintsev, G., et al., Init. Repts. DSDP, 38: Washington (U.S. Govt. Printing Office), 857-895.

Müller, C., 1976. Tertiary and Quaternary calcareous nannoplankton in the Norwegian-Greenland Sea, DSDP, Leg 38. In Talwani, M., Udintsev, G., et al., Init. Repts. DSDP, 38: Washington (U.S. Govt. Printing Office), 823-841.

Myhre, A.M., Thiede, J., Firth, J.V., et al., 1995. Proc. ODP, Init. Repts., 151: College Station, TX (Ocean Drilling Program).

Nøhr-Hansen, H., 1993. Dinoflagellate cyst stratigraphy of the Barremian to Albian, Lower Cretaceous, North-East Greenland. Bull. Groenl. Geol. Unders., 166.

Osterman, L.E., and Qvale, G., 1989. Benthic foraminifers from the Vøring Plateau (ODP Leg 104). In Eldholm, O., Thiede, J., Taylor, E., et al., Proc. ODP, Sci. Results, 104: College Station, TX (Ocean Drilling Program), 745-768.

Powell, A.J., 1992. Dinoflagellate cysts of the Tertiary System. In Powell, A.J. (Ed.), A Stratigraphic Index of Dinoflagellate Cysts: London (Chapman and Hall), 155-251.

Schrader, H.-J., and Fenner, J., 1976. Norwegian Sea Cenozoic diatom biostratigraphy and taxonomy. In Talwani, M., Udintsev, G., et al., Init. Repts. DSDP, 38: Washington (U.S. Govt. Printing Office), 921-1099.

Spiegler, D., and Jansen, E., 1989. Planktonic foraminifer biostratigraphy of Norwegian Sea sediments: ODP Leg 104. In Eldholm, O., Thiede, J., Taylor, E., et al., Proc. ODP, Sci. Results, 104: College Station, TX (Ocean Drilling Program), 681-696.

Stover, L.E., and Williams, G.L., 1995. A revision of the Paleogene dinoflagellate genera Areosphaeridium Eaton 1971 and Eatonicysta Stover and Evitt 1978. Micropaleontology, 41:97-141.

Talwani, M., and Eldholm, O., 1977. Evolution of the Norwegian-Greenland Sea. Geol. Soc. Am. Bull., 88:969-999.

Talwani, M., Udintsev, G., et al., 1976. Init. Repts. DSDP, 38: Washington (U.S. Govt. Printing Office).

Wetzel, O., 1961. New microfossils from Baltic Cretaceous flintstones. Micropaleontology, 7:337-350.

Williams, G.L., and Bujak, J.P., 1985. Mesozoic and Cenozoic dinoflagellates. In Bolli, H.M, Saunders, J.B., and Perch-Nielsen, K. (Eds.), Plankton Stratigraphy: Cambridge (Cambridge Univ. Press), 847-964.

Williams, G.L., Stover, L.E., and Kidson, E.J., 1993. Morphology and Stratigraphic Ranges of Selected Mesozoic-Cenozoic Dinoflagellate Taxa in the Northern Hemisphere. Pap.-Geol. Surv. Can., 92-10.

Date of initial receipt: 30 June 1995

Date of acceptance: 30 December 1995

Ms 151SR-105 


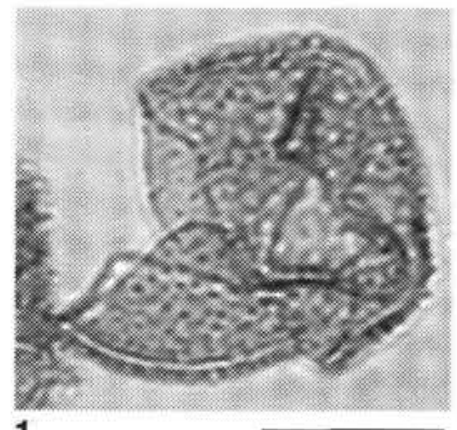

1
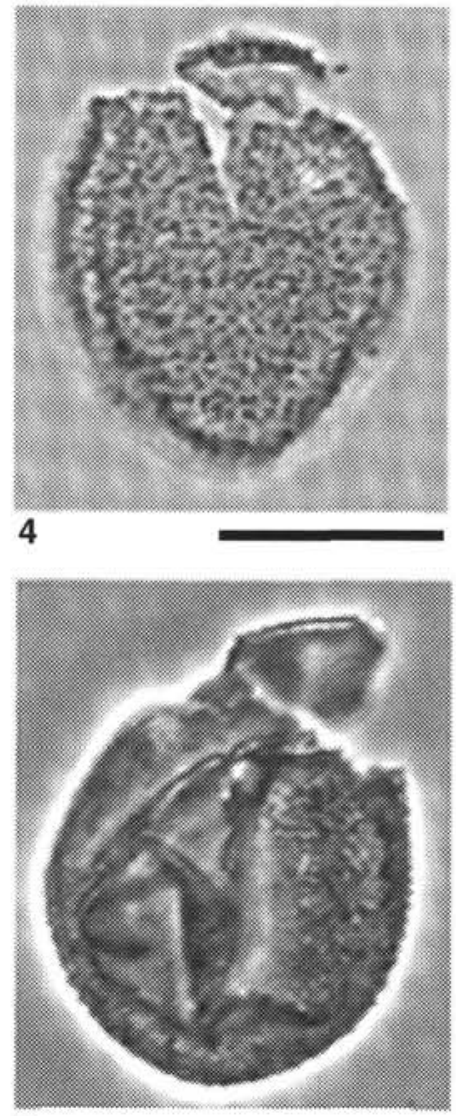

7
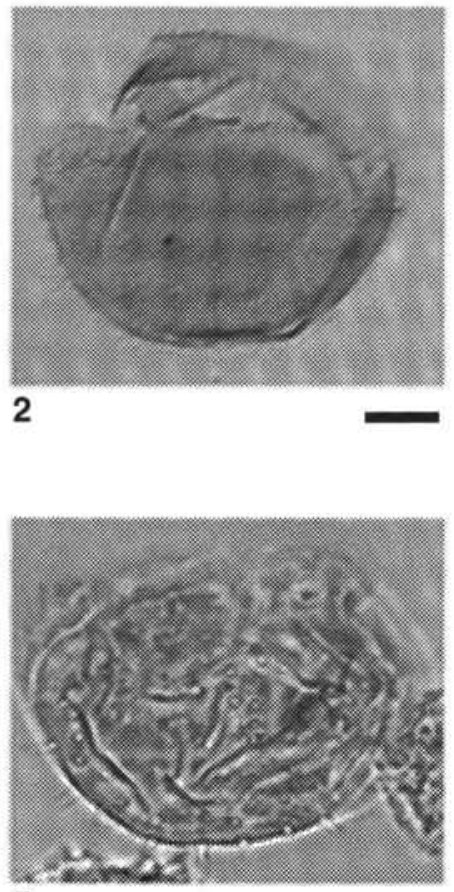

5

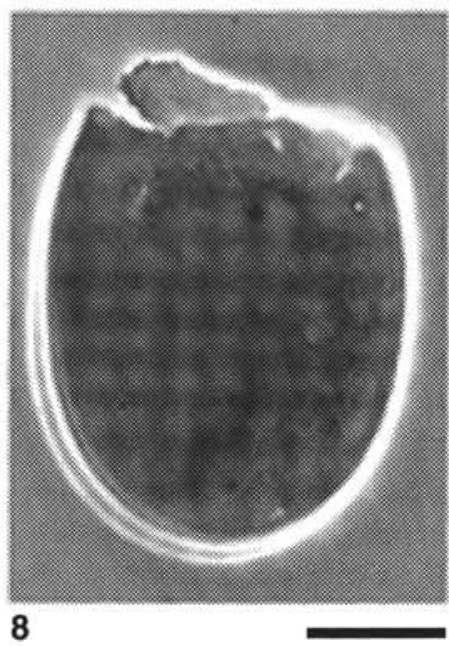

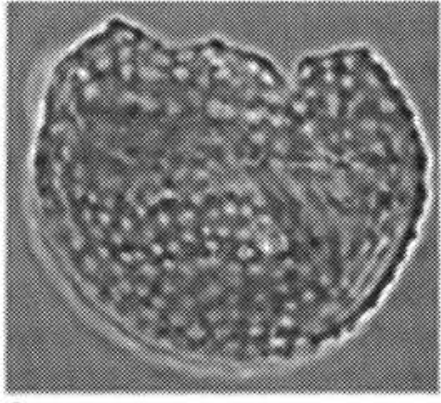

3

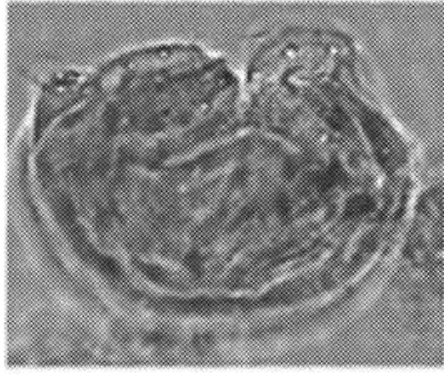

6

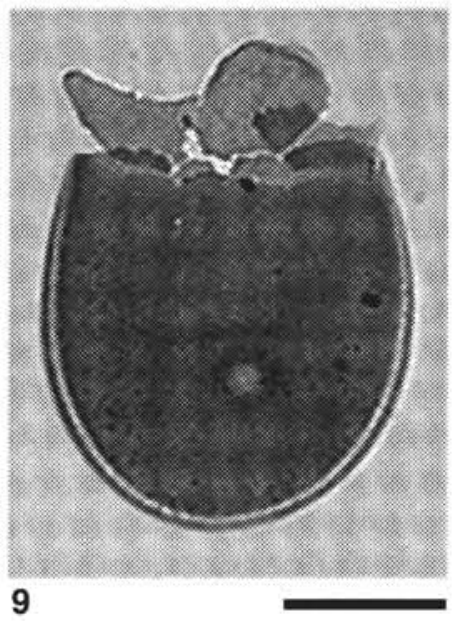

Plate 1. For all plates, the species name is followed by the sample ID in which the specimen was found; the sample depth (mbsf); the England Finder coordinates for the specimen on the slide; and the type of illumination used for the photograph-PH for phase contrast, IC for interference contrast, and TR for transmitted light. All scale bars $=25 \mu \mathrm{m}$, except where noted. 1. Batiacasphaera baculata; 913B-24R-2, 77-79 cm; 464.27 mbsf; K32-1; PH. 2. Batiacasphaera hirsuta; scale bar $=10 \mu \mathrm{m}$; 913B-33R-2, 100-104 cm; 550.90 mbsf; H39; IC. 3. Batiacasphaera compta; 913B-24R-2, 77-79 cm; 464.27 mbsf; E29-1; PH. 4. Batiacasphaera micropapillata sensu lato; 913B-29R-4, 100-103 cm; 515.40 mbsf; P29-4; PH. 5. Batiacasphaera sp.; 913B-34R-2, 103-105 cm; 560.68 mbsf; T40; PH. 6. Batiacasphaera sp.; 913B-34R-2, 103-105 cm; 560.68 mbsf; T40; PH. 7. Batiacasphaera sp.; 913B-26R-2, 100-102 cm; 483.60 mbsf; O29; PH. 8. Caligodinium amiculum; 913B-31R-1, 99-104 cm; 530.19 mbsf; V30-4; PH. 9. Caligodinium amiculum; 913B-26R-6, $100-102$ cm; 489.60 mbsf; R34; TR. 

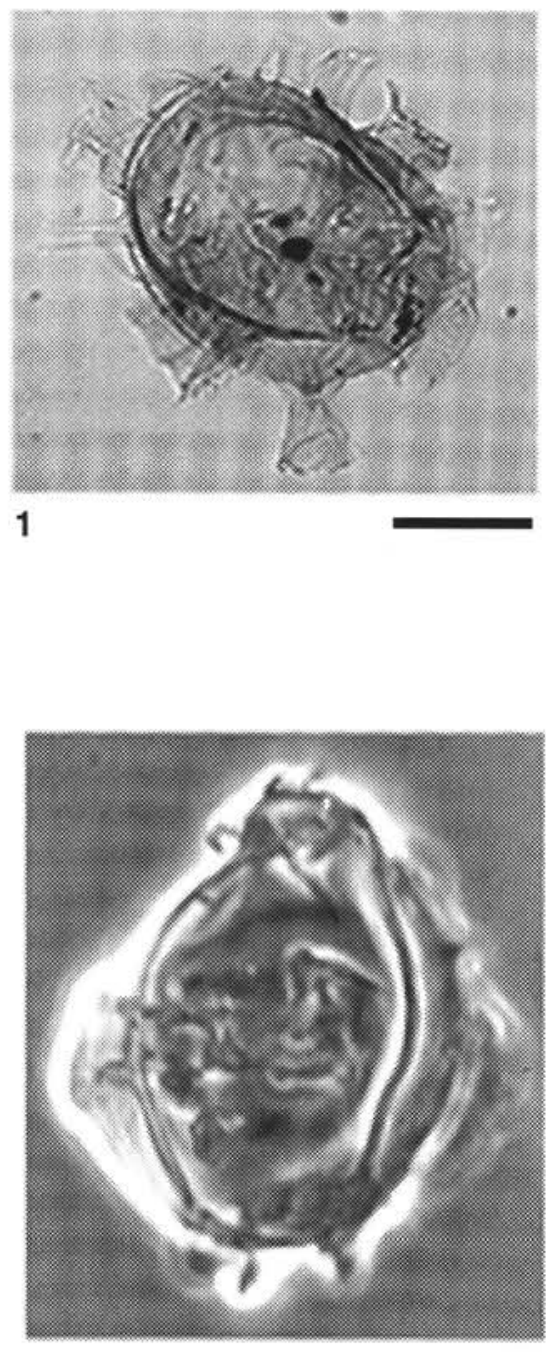

4

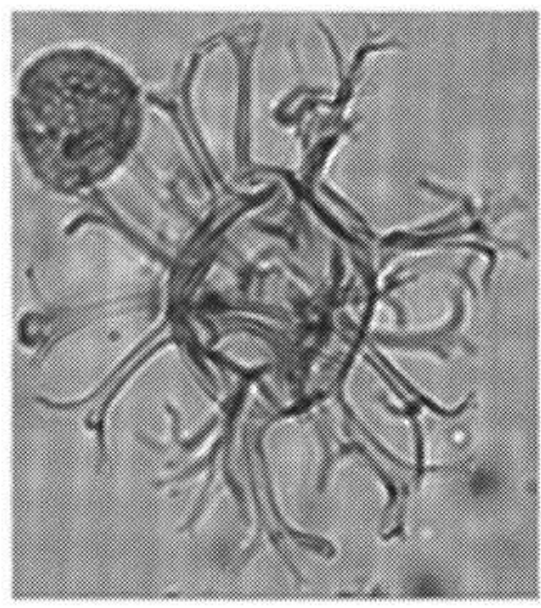

2

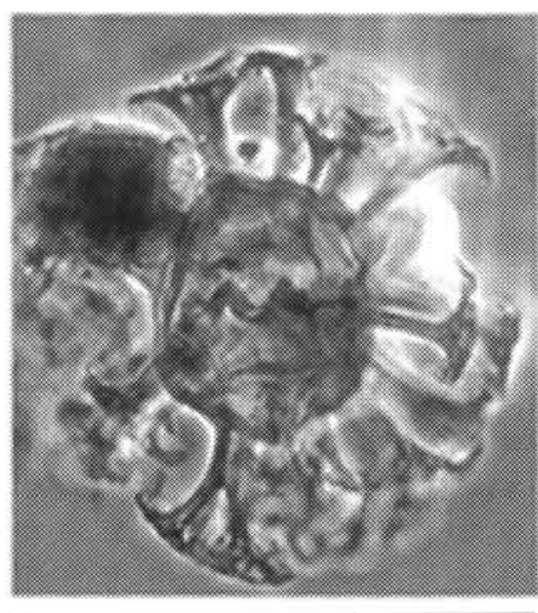

5

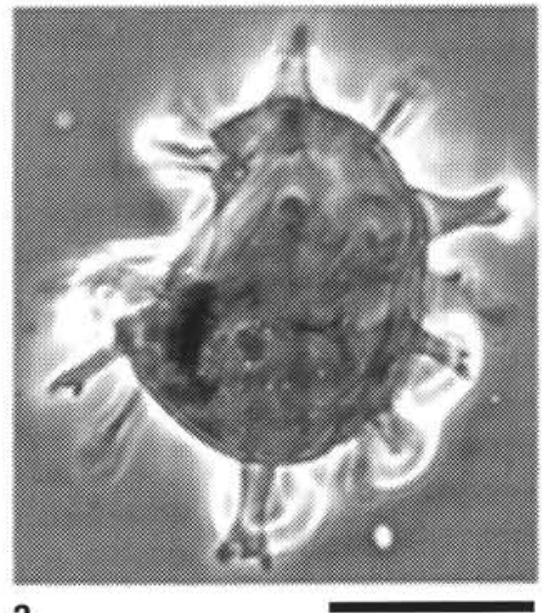

3

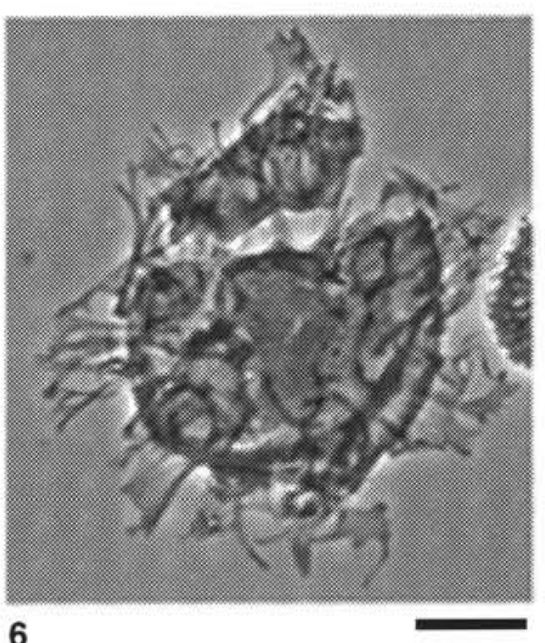

Plate 2. 1. Achilleodinium biformoides; scale bar $=25 \mu \mathrm{m} ; 913 \mathrm{~B}-28 \mathrm{R}-1,35-38 \mathrm{~cm} ; 500.65 \mathrm{mbsf} ; \mathrm{T} 36 ;$ TR. 2. Achomosphaera alcicornu; scale bar $=50 \mu \mathrm{m}$; 913-24R-2, 77-79 cm; 464.27 mbsf; Q32-1; TR. 3. Achomosphaera sp.; scale bar $=50 \mu \mathrm{m}$; 913B-34R-2, 103-105 cm; $560.68 \mathrm{mbsf}$; T40-4; PH. 4. Achomosphaera sp.; scale bar $=25 \mu \mathrm{m}$; 913B-34R-2, 103-105 cm; $560.68 \mathrm{mbsf}$; W34; PH. 5. Araneosphaera araneosa; scale bar $=50 \mu \mathrm{m} ; 913 \mathrm{~B}-33 \mathrm{R}-2,100-104 \mathrm{~cm}$; 550.90 mbsf; D28-4; PH. 6. Areoligera sp.; scale bar $=25$ m; 913B-20R-2, 98-102 cm; 425.98 mbsf; Q39-3; PH. 


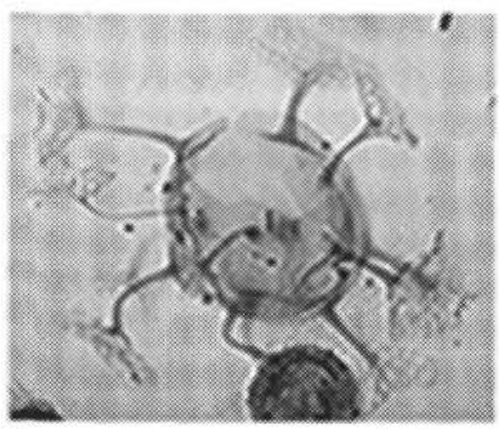

1

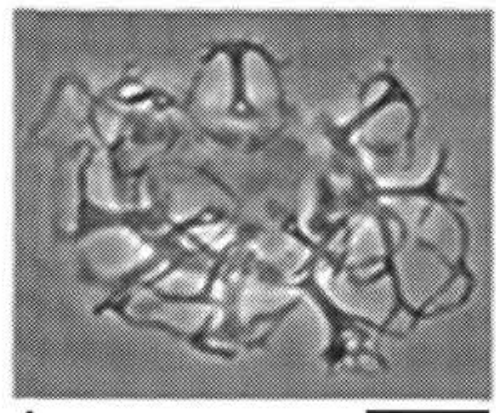

4

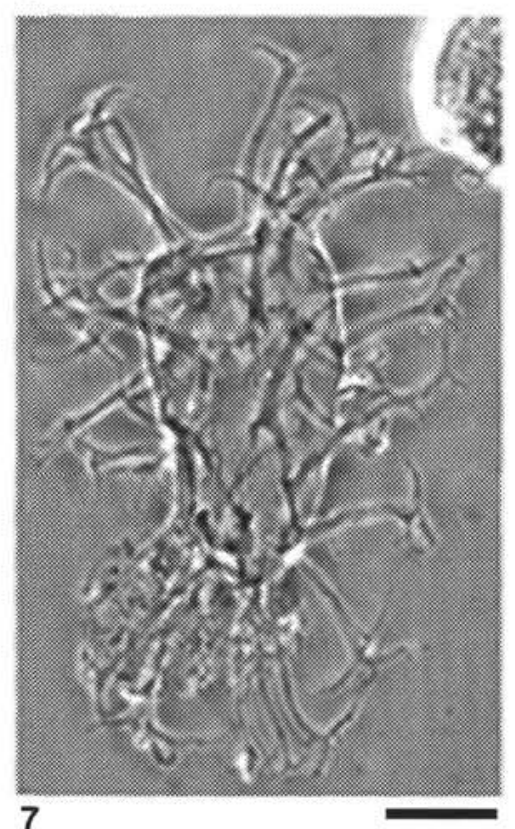

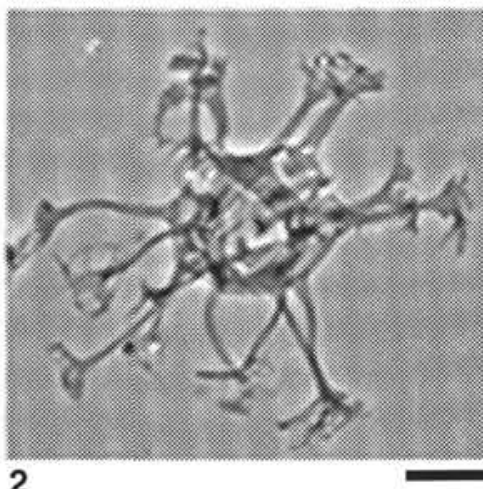

2

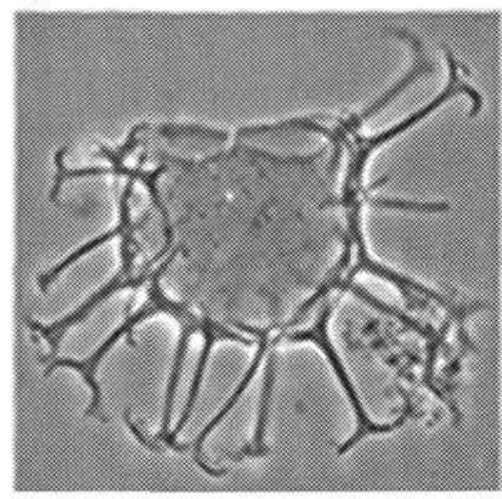

5

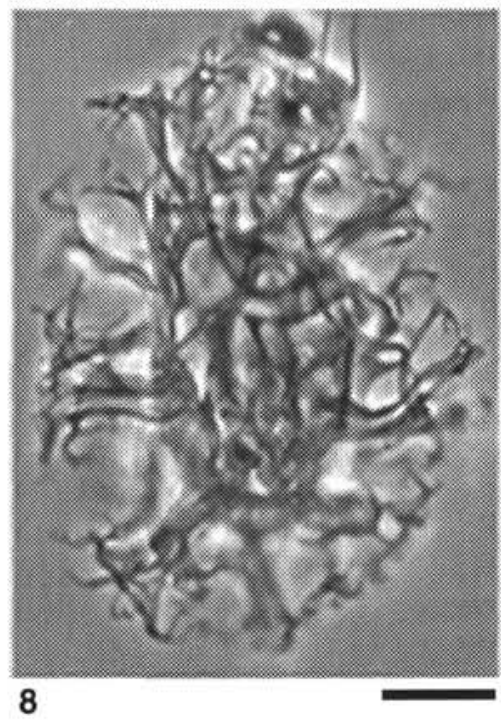

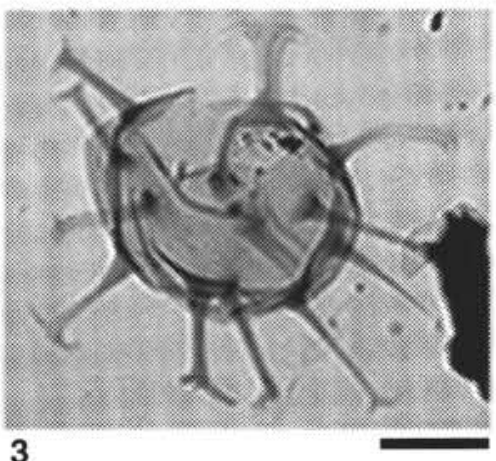

3

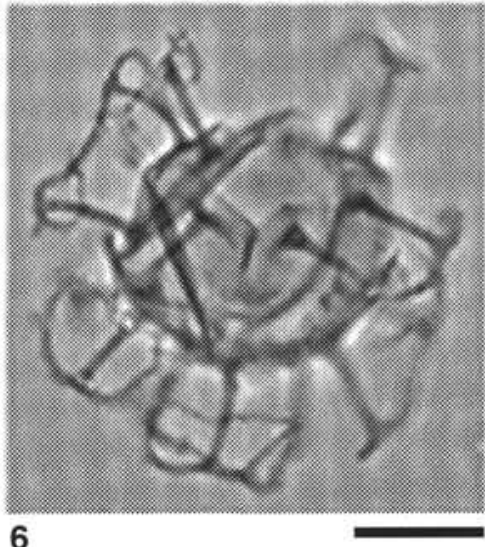

6

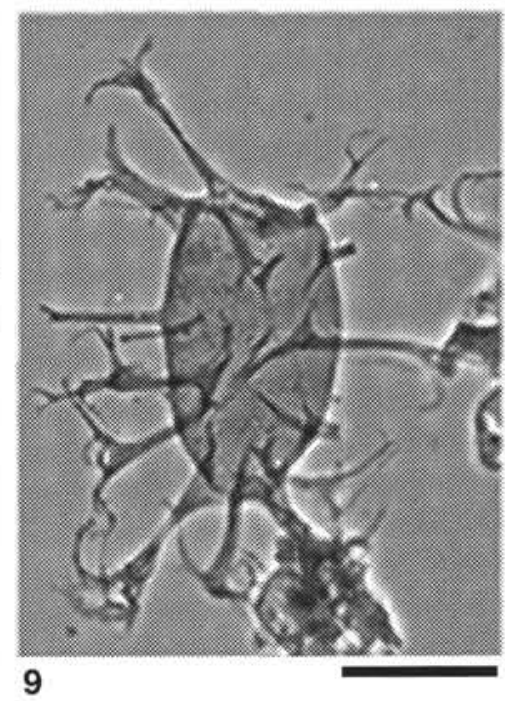

Plate 3. All scale bars $=25 \mu \mathrm{m}$, except where noted. 1. Areosphaeridium diktyoplokus; 913B-28R-1, 35-38 cm; 500.65 mbsf; N31-1; TR. 2. Enneadocysta fenestrata; 913B-25R-6, 100-102 cm; 480.05 mbsf; J32-1; PH. 3. Areosphaeridium michoudii; 913B-28R-1, 35-38 cm; 500.65 mbsf; O31; TR. 4. Enneadocysta multicornuta; 913B-24R-4, 68-70 cm; 467.18 mbsf; S33-2; PH. 5. Enneadocysta arcuata; 913B-24R-2, 77-79 cm; 464.27 mbsf; N38-3; PH. 6. Enneadocysta arcuata; 913B-31R-1; 530.19 mbsf; J34; PH. 7. Distatodinium ellipticum; 913B-24R-2, 77-79 cm; 464.27 mbsf; E31-1; PH. 8. Distatodinium ellipticum; 913B-33R-2, 100-104 cm; 550.90 mbsf; F33-4; PH. 9. Distatodinium paradoxum; scale bar $=50 \mu \mathrm{m} ; 913 \mathrm{~B}-20 \mathrm{R}-2$, $98-102 \mathrm{~cm} ; 425.98 \mathrm{mbsf}$; M423 ; $\mathrm{PH}$. 


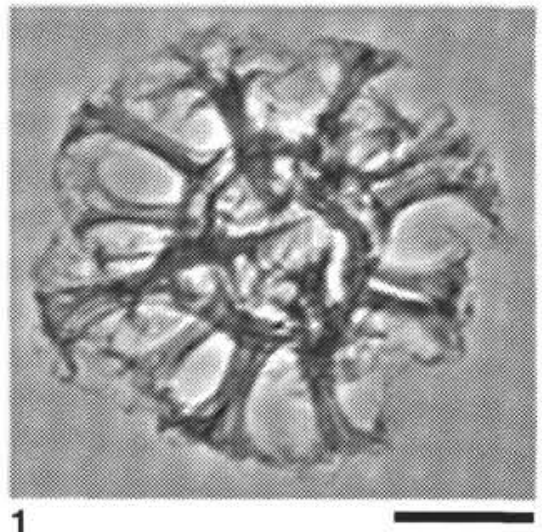

1

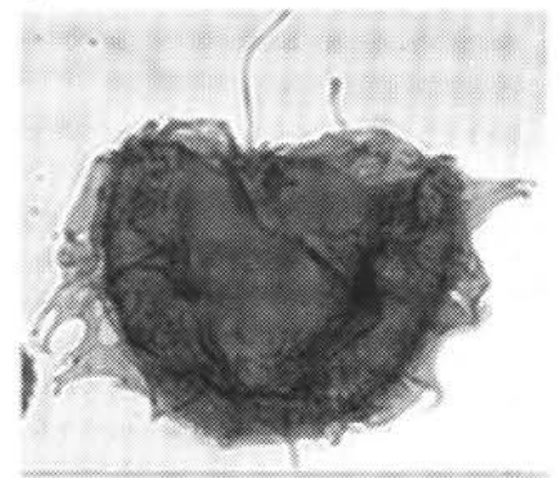

4

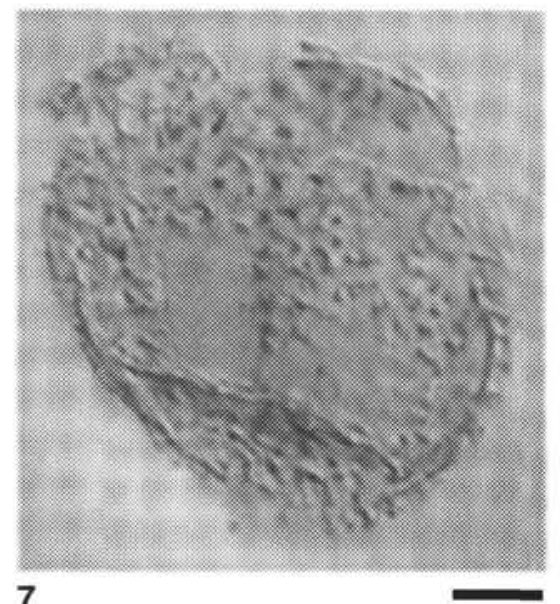

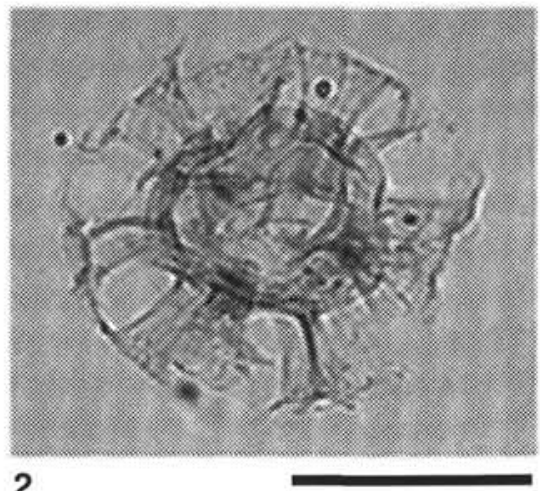

2

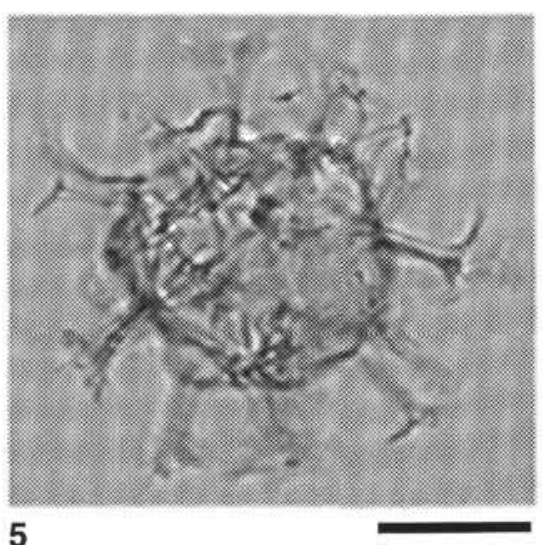

5

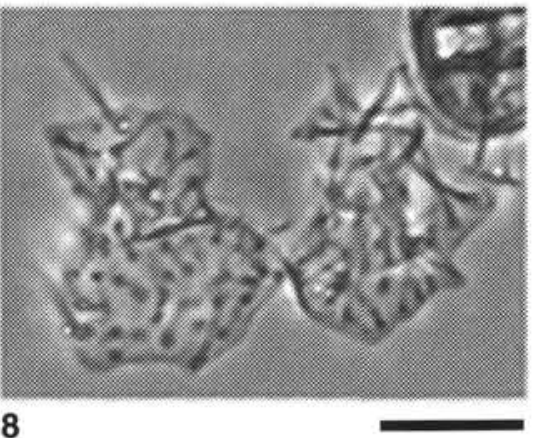

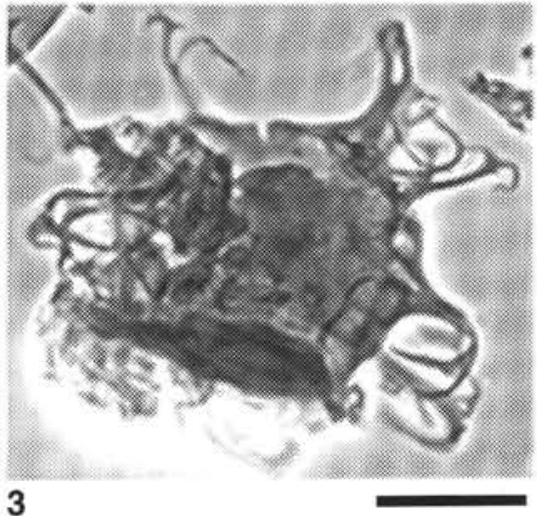
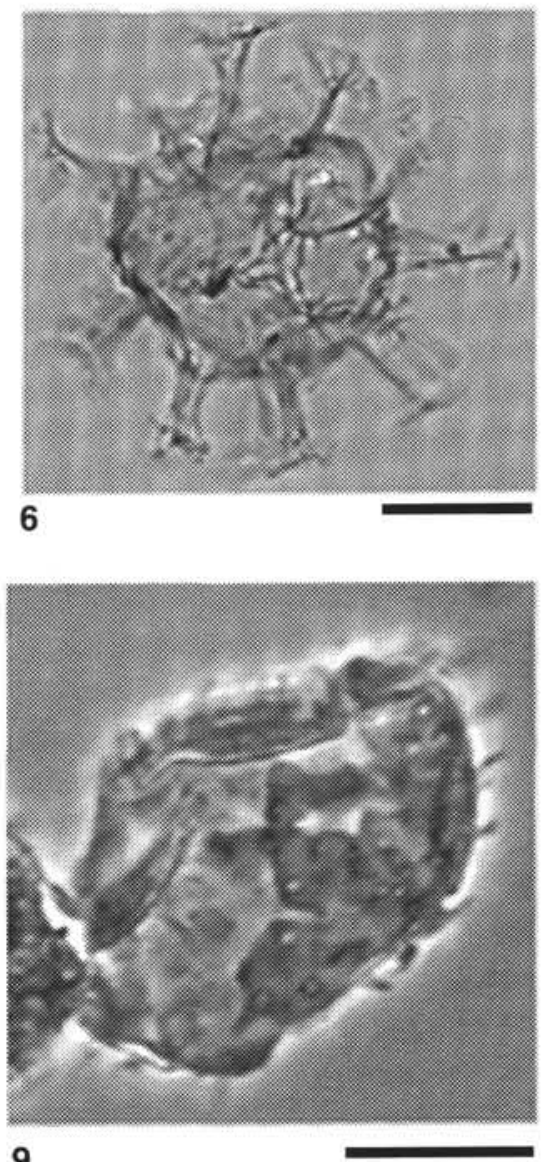

9

Plate 4. All scale bars $=25 \mu \mathrm{m}$, except where noted. 1. Cordosphaeridium cantharellum; 913B-28R-1, 35-38 cm; $500.65 \mathrm{mbsf} ; \mathrm{T} 40 ; \mathrm{PH}$. 2. Cordosphaeridium minimum; 913B-25R-2; 110-113 cm; 474.20 mbsf; C32; TR. 3. Chiropteridium lobospinosum; scale bar $=50 \mu \mathrm{m} ; 913 \mathrm{~B}-20 \mathrm{R}-2,98-102 \mathrm{~cm} ; 425.98 \mathrm{mbsf}$; M423; PH. 4. Chiropteridium galea; 913B-20R-2, 98-102 cm; $425.98 \mathrm{mbsf}$; O30-2; TR. 5. Cordosphaeridium funiculatum; 913B-24R-5, 54-56 cm; 468.54 mbsf; J36; PH. 6. Cordosphaeridium funiculatum; 913B-24R-5, 54-56 cm; $468.54 \mathrm{mbsf} ; \mathrm{J} 36$; PH. 7. Elytrocysta sp. 1; scale bar = $10 \mu \mathrm{m} ; 913 \mathrm{~B}-33 \mathrm{R}-2$, 100-104 cm; 550.90 mbsf; G41-3; IC. 8. Eocladopyxis peniculata; 913B-31R-1, 99-104 cm; 530.19 mbsf; P28; PH. 9. Eocladopyxis peniculata; 913B-31R-1, 99-104 cm; 530.19 mbsf; K32-2; PH. 

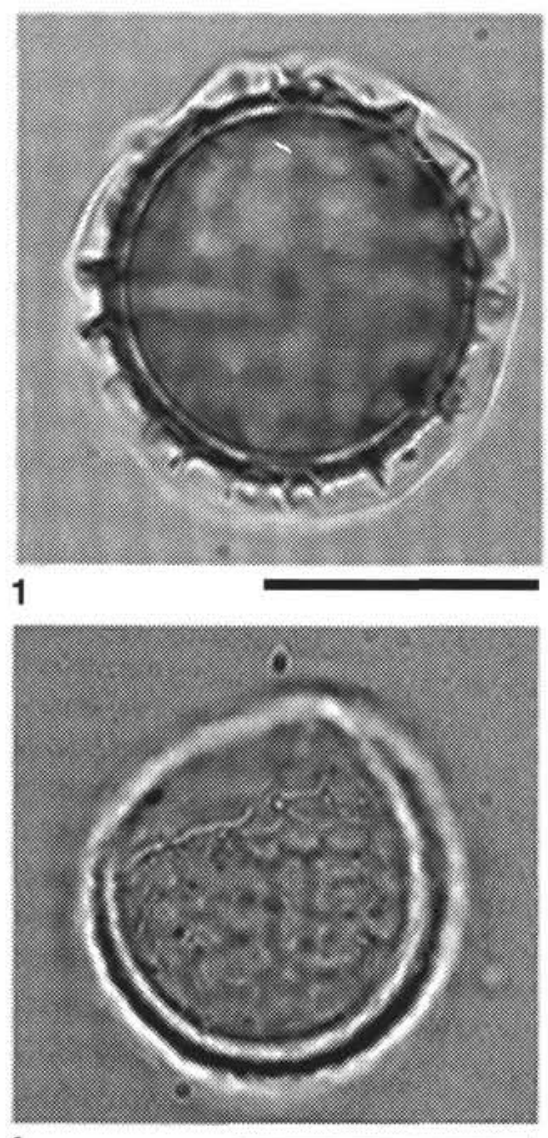

4

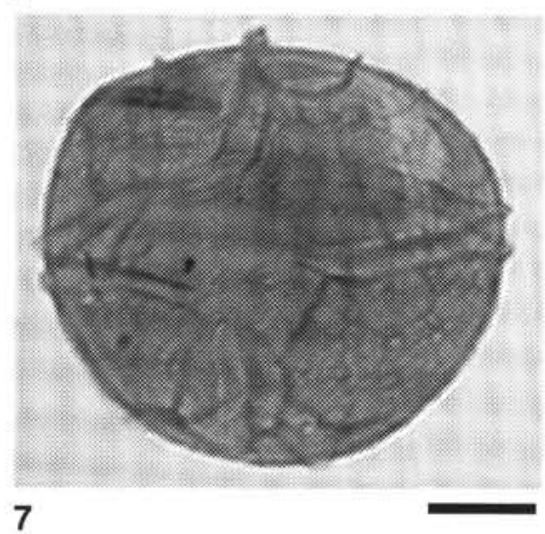

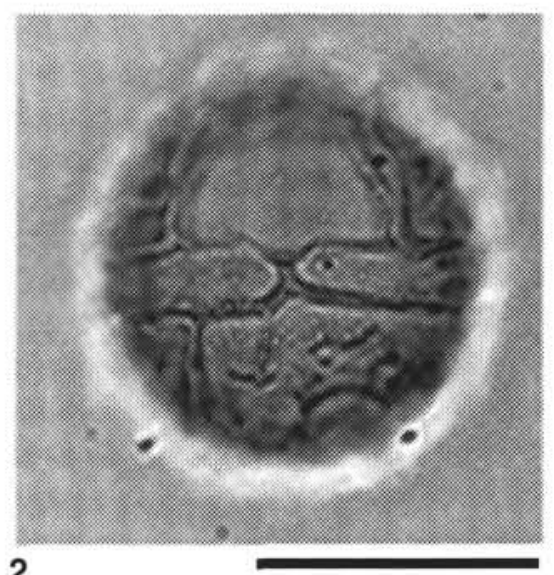

2

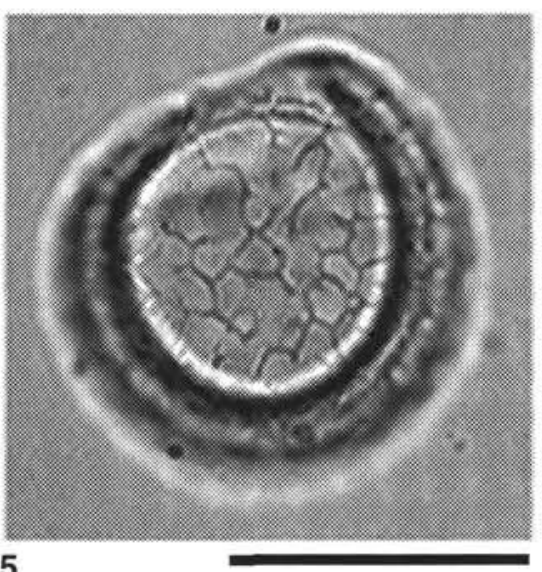

5

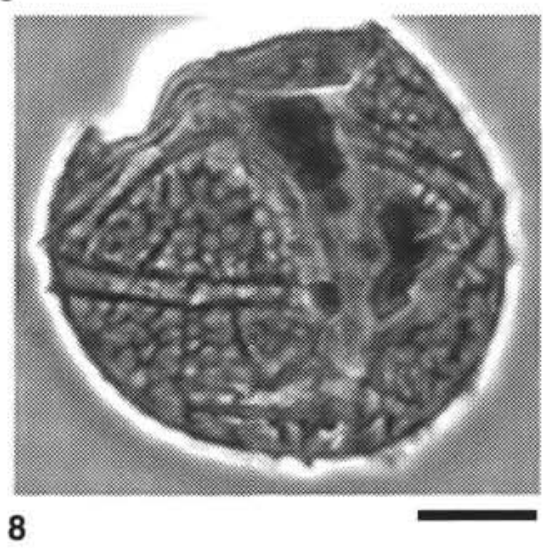

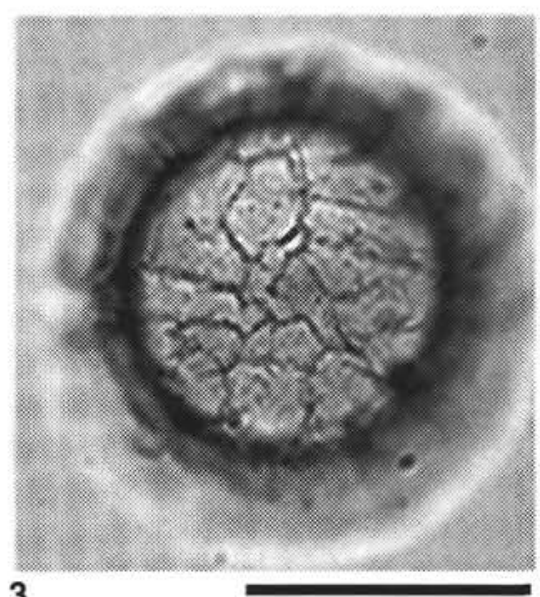

3
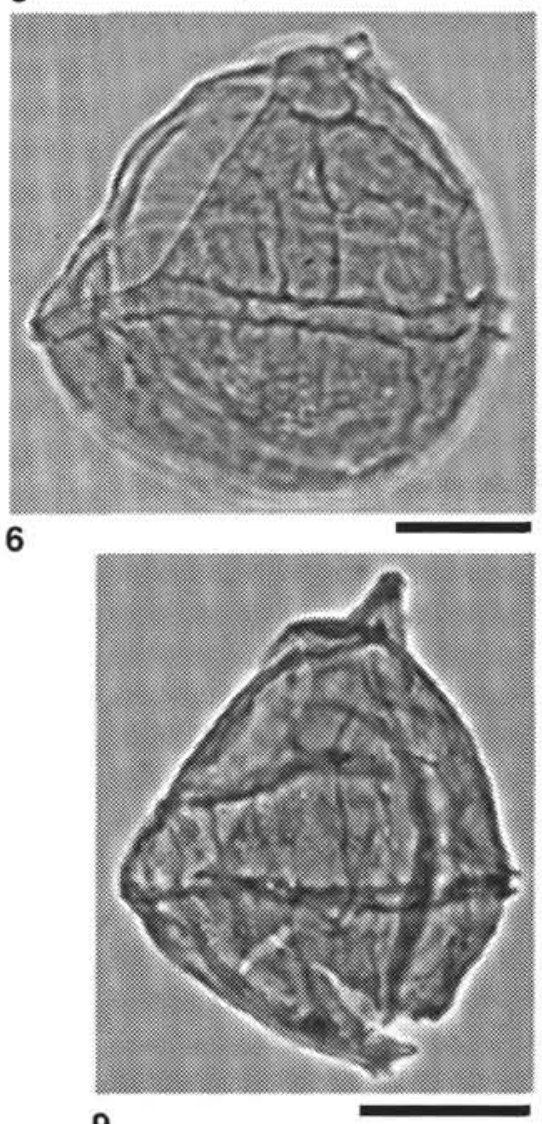

9

Plate 5. All scale bars $=25 \mu \mathrm{m}$, except where noted. 1. Corrudinium incompositum; 913B-26R-6, 100-102 cm; 489.60 mbsf; N45; TR. 2. Corrudinium incompositum; 913B-26R-6, 100-102 cm; 489.60 mbsf; N45; TR. 3. Corrudinium incompositum; 913B-26R-6, 100-102 cm; 489.60 mbsf; N45; TR. 4. Cerebrocysta bartonensis; 913B-25R-2, 110-113 cm; 474.20 mbsf; Q27-1; TR. 5. Cerebrocysta bartonensis; 913B-25R-2, 110-113 cm; 474.20 mbsf; Q27-1; TR. 6. Cribroperidinium giuseppei; 913B-24R-2, 77-79 cm; 464.27 mbsf; J34; PH. 7. Cribroperidinium sp. 2; 913B-31R-1, 99-104 cm; 530.19 mbsf; F36; TR. 8. Cribroperidinium sp. 2; 913B-31R-1, 99-104 cm; 530.19 mbsf; G39; PH. 9. Cribroperidinium tenuitabulatum; scale bar $=50 \mu \mathrm{m} ; 913 \mathrm{~B}-28 \mathrm{R}-1$, $35-38 \mathrm{~cm} ; 500.65 \mathrm{mbsf}$; P39; PH. 


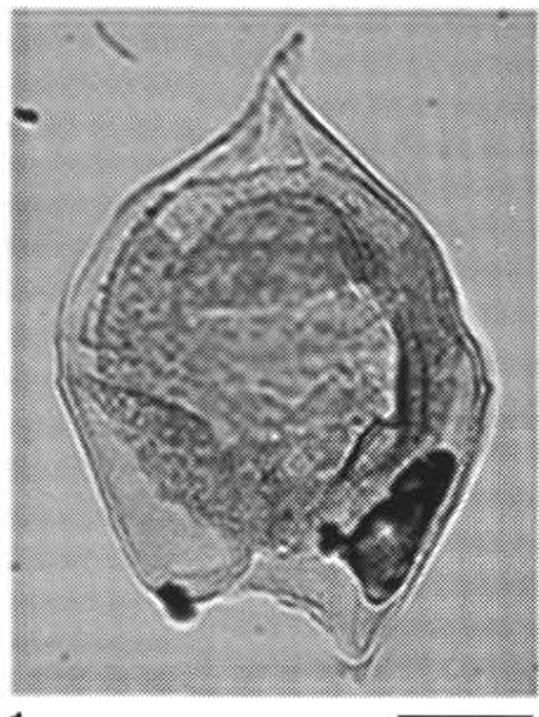

1

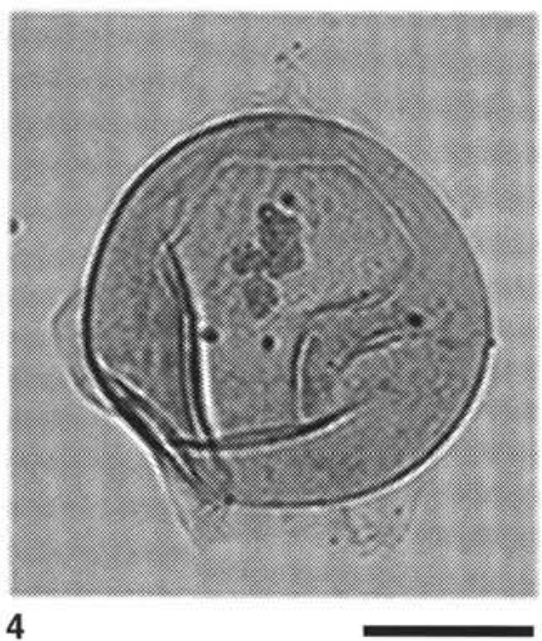

4

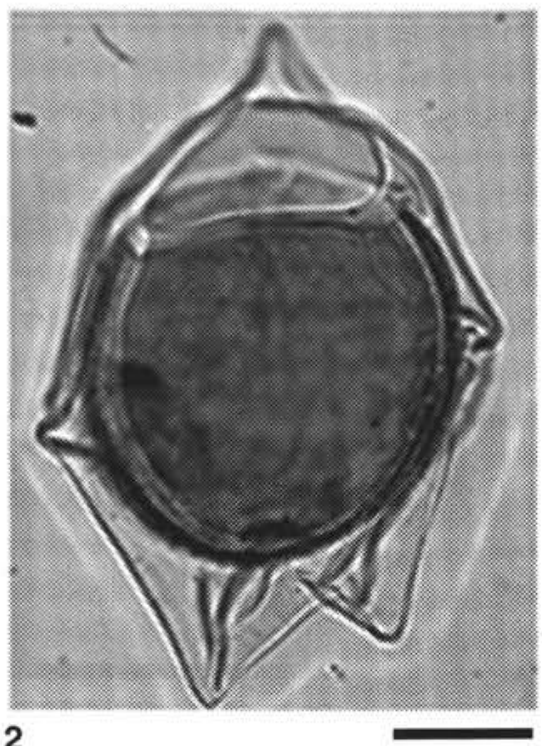

2

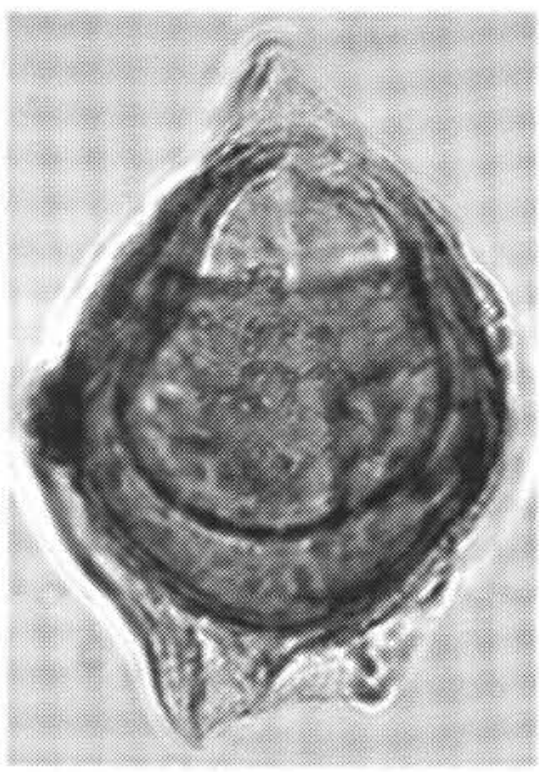

5
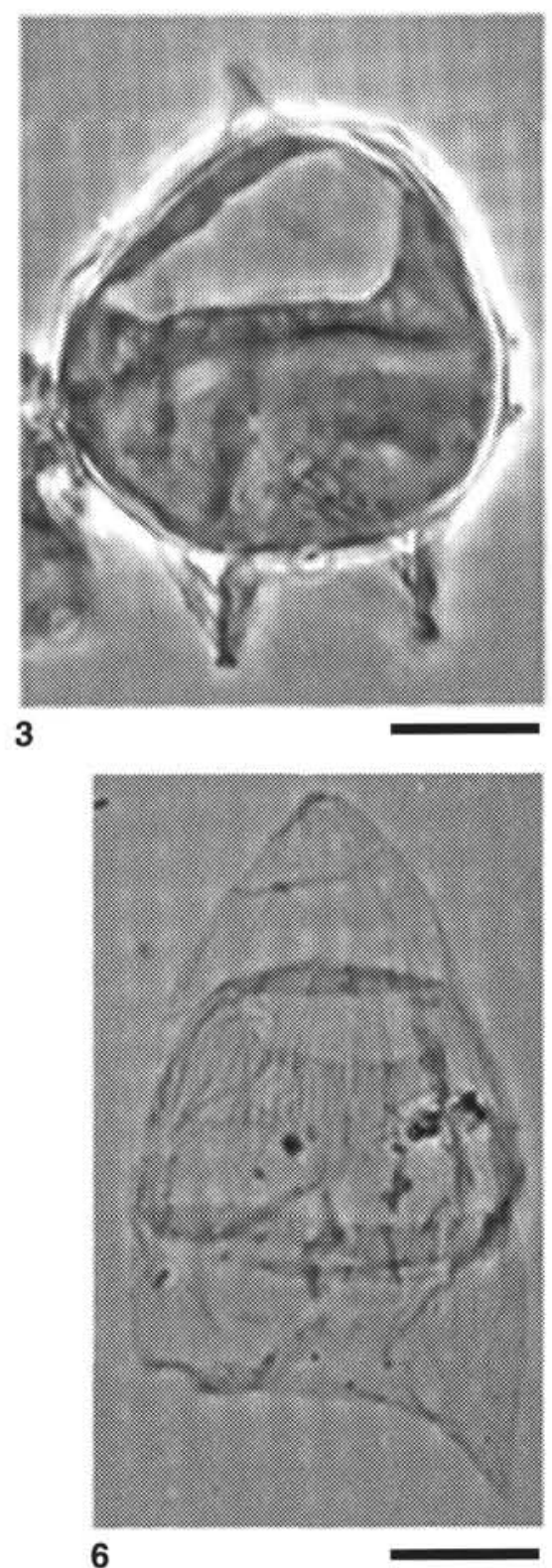

Plate 6. All scale bars $=25 \mu \mathrm{m}$. 1. Deflandrea granulata; 913B-26R-6, 100-102 cm; $489.60 \mathrm{mbsf}$; U45; TR. 2. Deflandrea phosphoritica; 913B-26R-6, 100$102 \mathrm{~cm} ; 489.60$ mbsf; N40; TR. 3. Deflandrea sp. 1; 913B-25R-6, 100-102 cm; 480.05 mbsf; P32-4; PH. 4. Deflandrea sp. 1; 913B-25R-6, 95-97 cm; 480.05 mbsf; J43; TR. 5. Deflandrea sp. 2; 913B-32R-2, 104-107 cm; 541.34 mbsf; H30-2; TR. 6. Deflandrea sp. 3; 913B-24R-5, 54-56 cm; 468.54 mbsf; Q45-1; PH. 


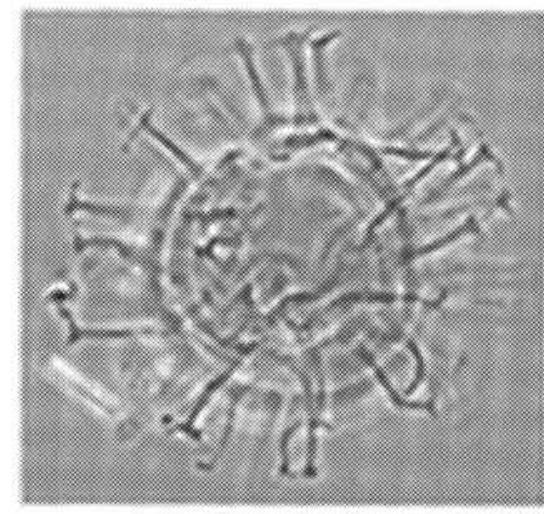

1
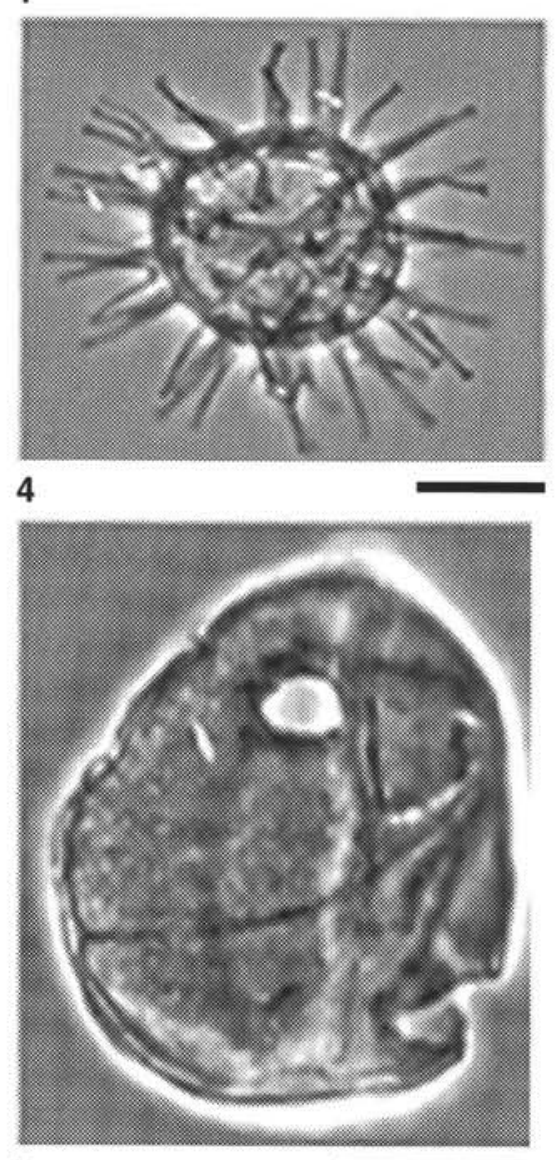

7

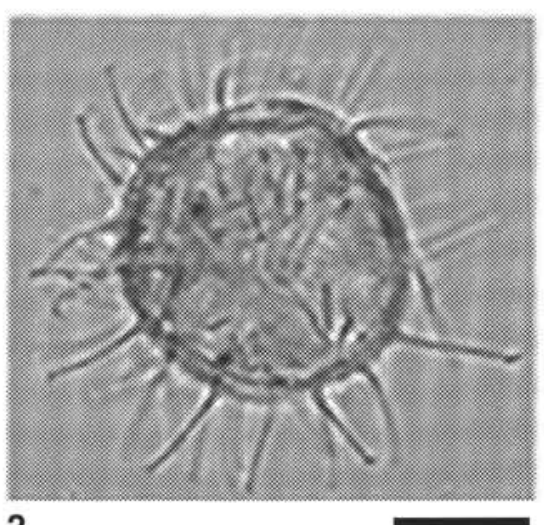

2

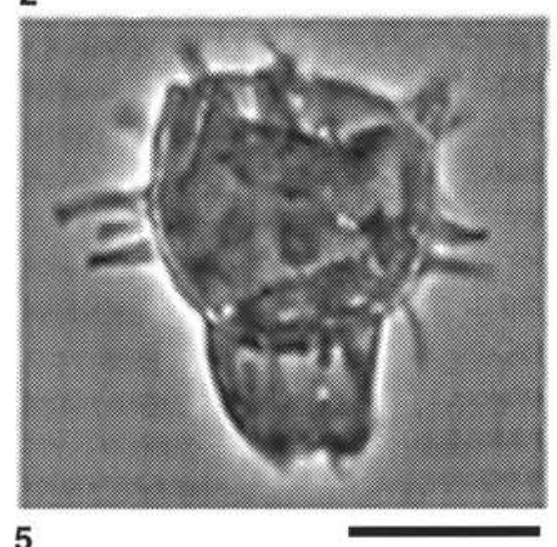

5

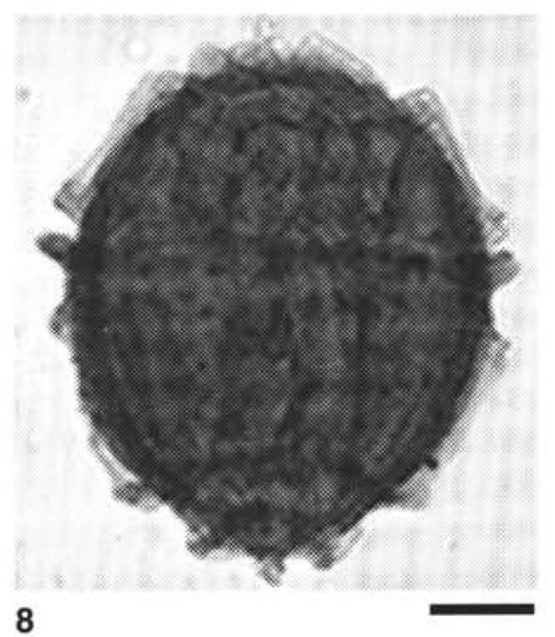

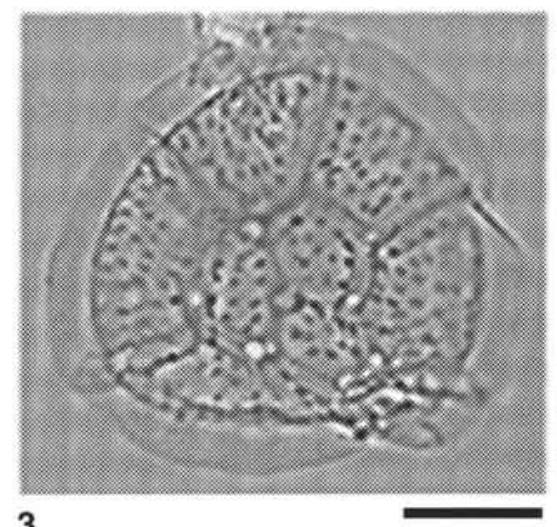

3

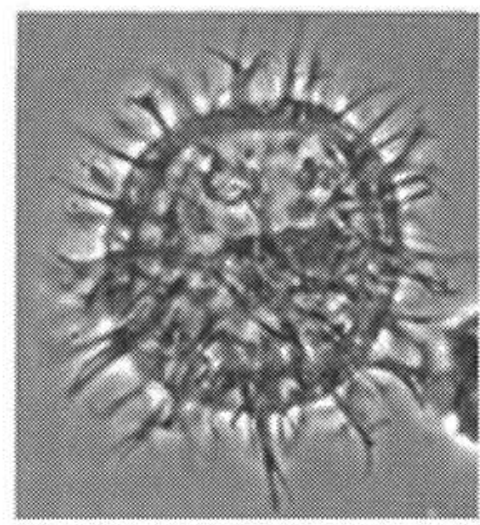

6

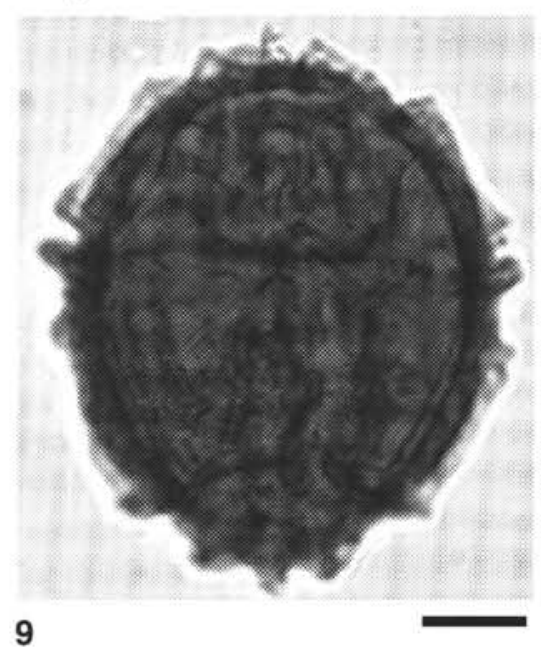

Plate 7. All scale bars $=25 \mu \mathrm{m}$, except where noted. 1. Dapsilidinium pseudocolligerum; 913B-24R-2, 77-79 cm; 464.27 mbsf; J44; PH. 2. Dapsilidinium? sp. 1; 913B-26R-4, 100-102 cm; 486.60 mbsf; T34-4; PH. 3. Dinopterygium cladoides; 913B-24R-2, 77-79 cm; 464.27 mbsf; G35-1; PH. 4. Diphyes colligerum; 913B-34R-2, 103-105 cm; 560.68 mbsf; T39-1; PH. 5. Diphyes ficusoides (reworked); 913B-34R-2, 103-105 cm; 560.68 mbsf; Q36-1; PH. 6. Fibrocysta axialis; scale bar $=50 \mu \mathrm{m}$; 913B-30R-2, 97-101 cm; 521.97 mbsf; K37-3; PH. 7. Cyclopsiella elliptica; 913B-20R-2, 98-102 cm; 425.98 mbsf; F28; PH. 8. Damassadinium abbreviatum; 913B-34R-2, 103-105 cm; 560.68 mbsf; M42-1; TR. 9. Damassadinium abbreviatum; 913B-34R-2, $103-105$ cm; 560.68 mbsf; M42$1 ;$ TR. 


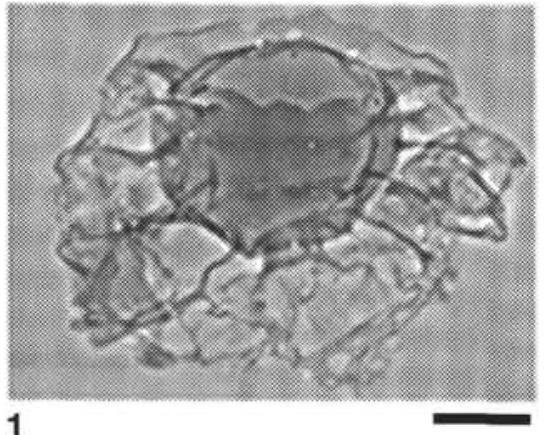

\section{1}

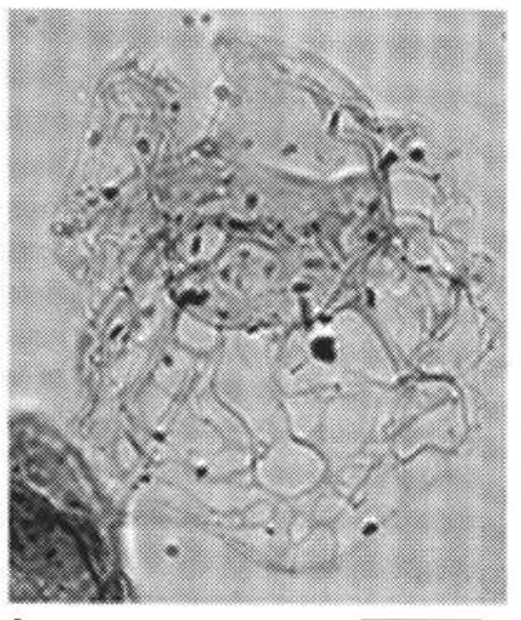

4

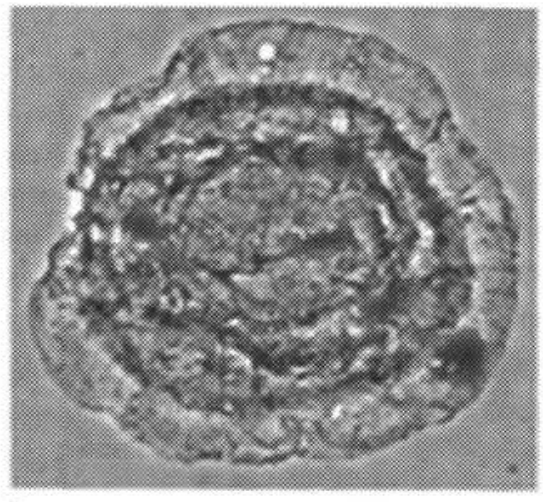

7

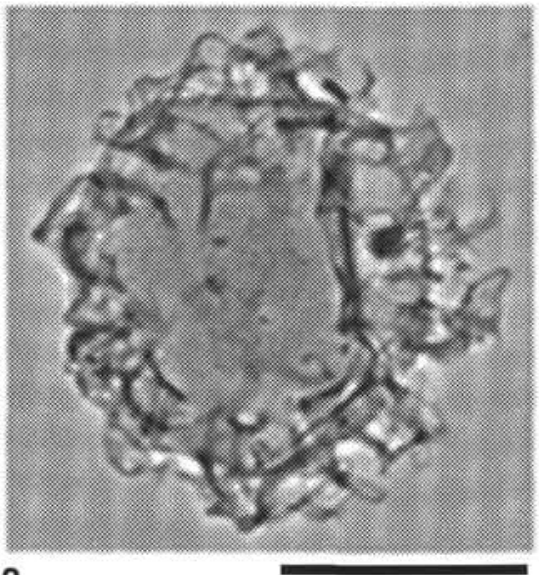

2

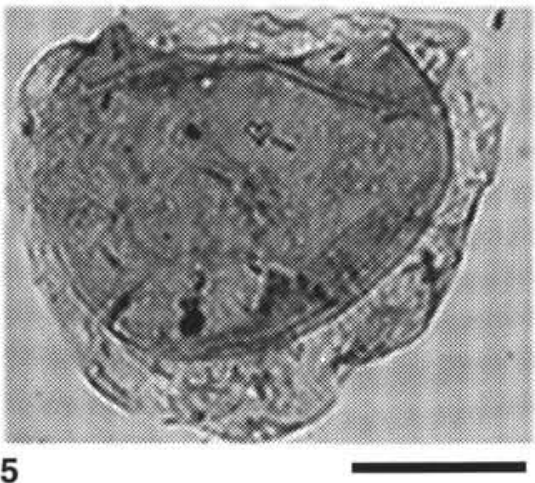

5

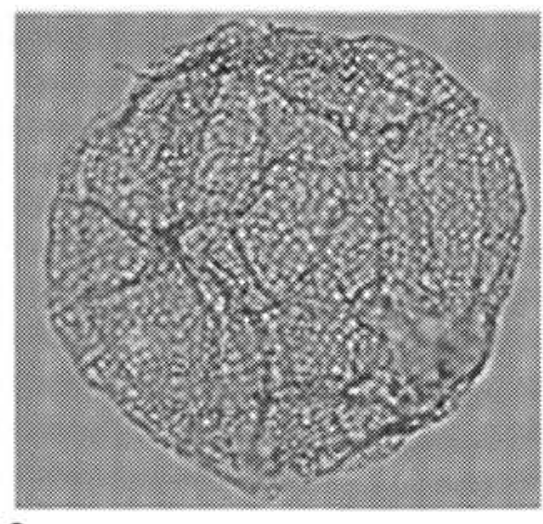

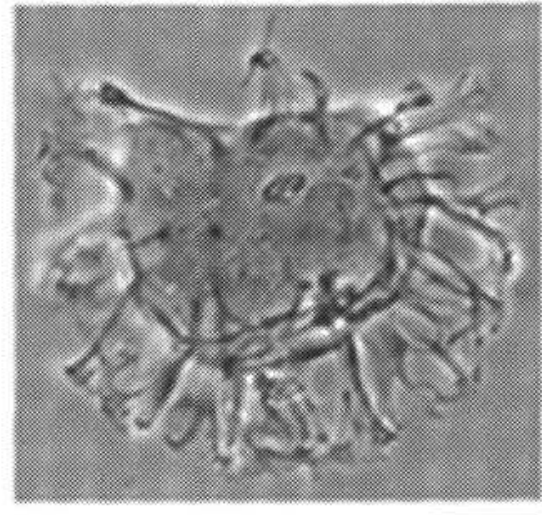

3

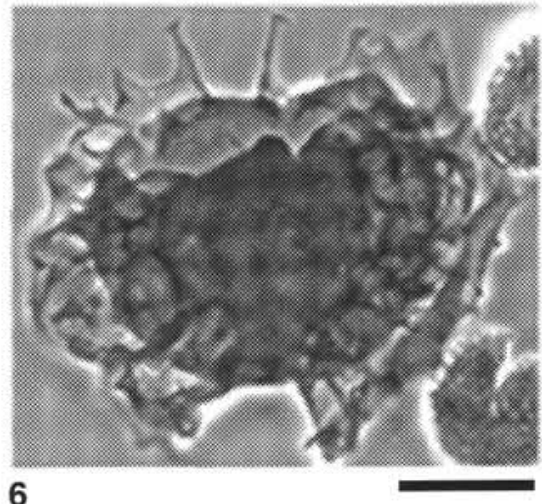

6

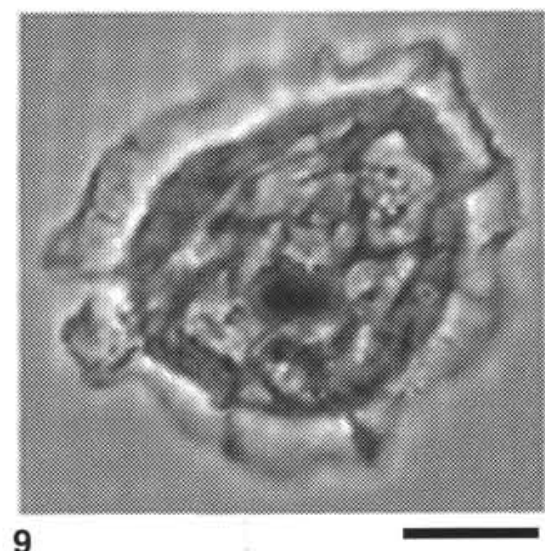

Plate 8. All scale bars $=25 \mu \mathrm{m}$, except where noted. 1. Glaphyrocysta semitecta; scale bar $=50 \mu \mathrm{m} ; 913 \mathrm{~B}-28 \mathrm{R}-1,35-38 \mathrm{~cm} ; 500.65 \mathrm{mbsf} ; \mathrm{T} 35 ; \mathrm{PH}$. 2. Glaphyrocysta divaricata; scale bar $=50 \mu \mathrm{m} ; 913 \mathrm{~B}-32 \mathrm{R}-2,104-107 \mathrm{~cm} ; 541.34 \mathrm{mbsf} ; \mathrm{V} 34 ; \mathrm{PH}$. 3. Glaphyrocysta ordinata; $913 \mathrm{~B}-30 \mathrm{R}-2,97-101 \mathrm{~cm} ; 521.97 \mathrm{mbsf}$; N29; PH. 4. Glaphyrocysta? reticulosa; 913B-26R-2, 100-102 cm; 483.60 mbsf; U41-2; TR. 5. Glaphyrocysta? vicina; 913B-26R-2; 100-102 cm; 483.60 mbsf; W32-3; TR. 6. Membranophoridium sp.; scale bar $=50 \mu \mathrm{m} ; 913 \mathrm{~B}-31 \mathrm{R}-1,99-104 \mathrm{~cm} ; 530.19 \mathrm{mbsf} ; \mathrm{G} 37$; PH. 7. Heteraulacacysta? leptalea; scale bar = $50 \mu \mathrm{m}$; 913B-36R-3, 103-105 cm; 581.42 mbsf; R27-2; PH. 8. Heteraulacacysta porosa; 913B-29R-4, 100-103 cm; $515.40 \mathrm{mbsf}$; G27; PH. 9. Heteraulacacysta sp. 1; 913B-33R-2, 100-104 cm; 550.90 mbsf; H29; PH. 


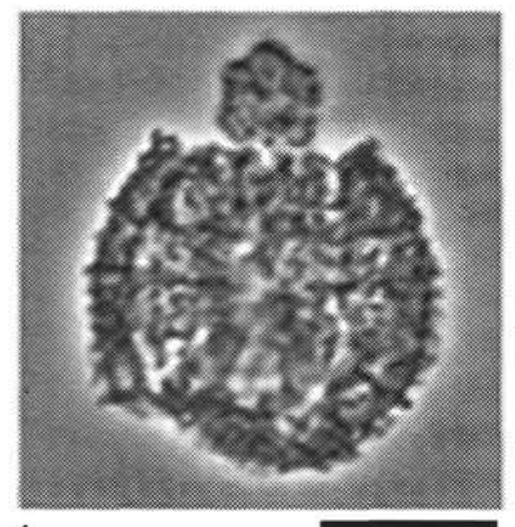

1
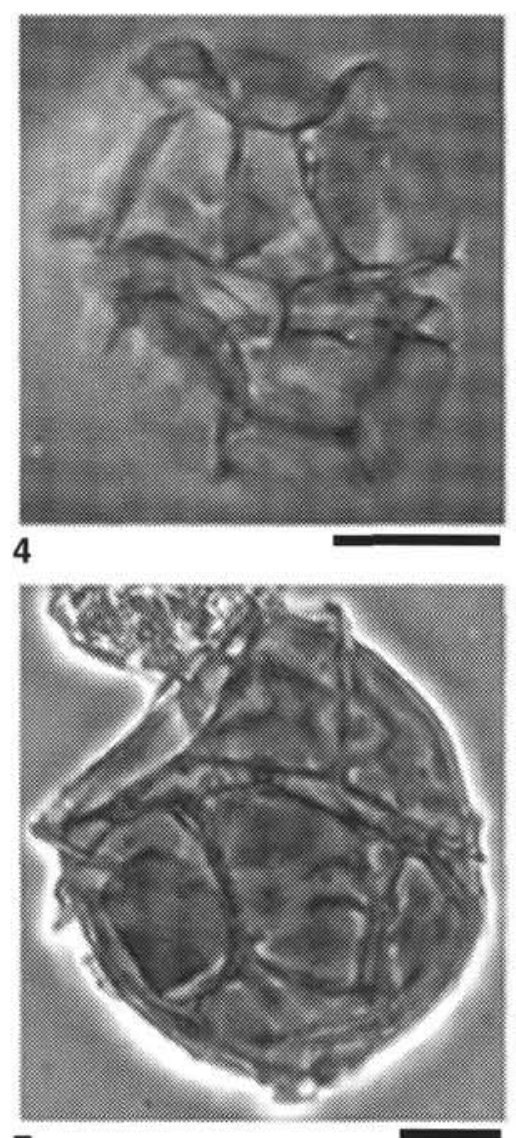

7

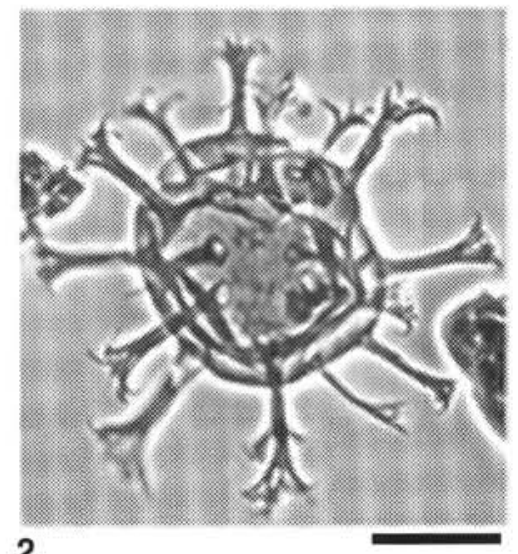

2

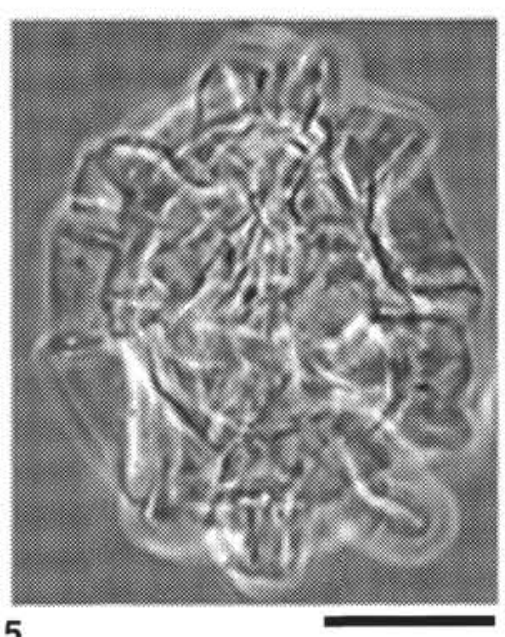

5

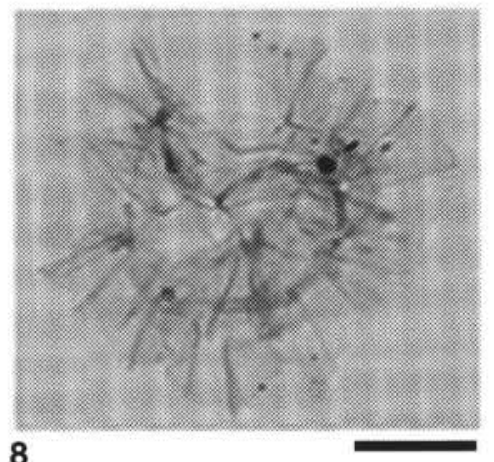

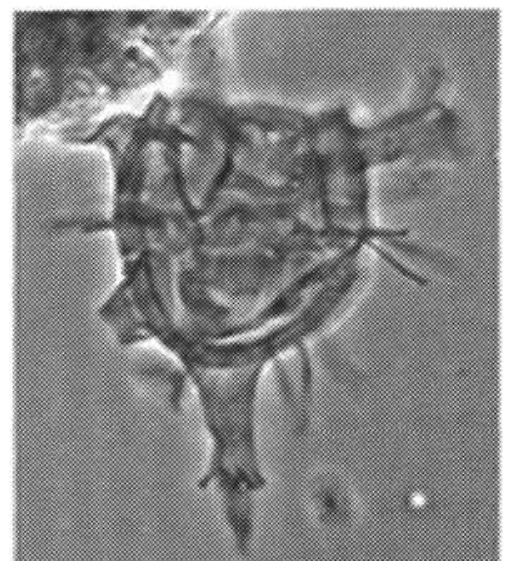

3
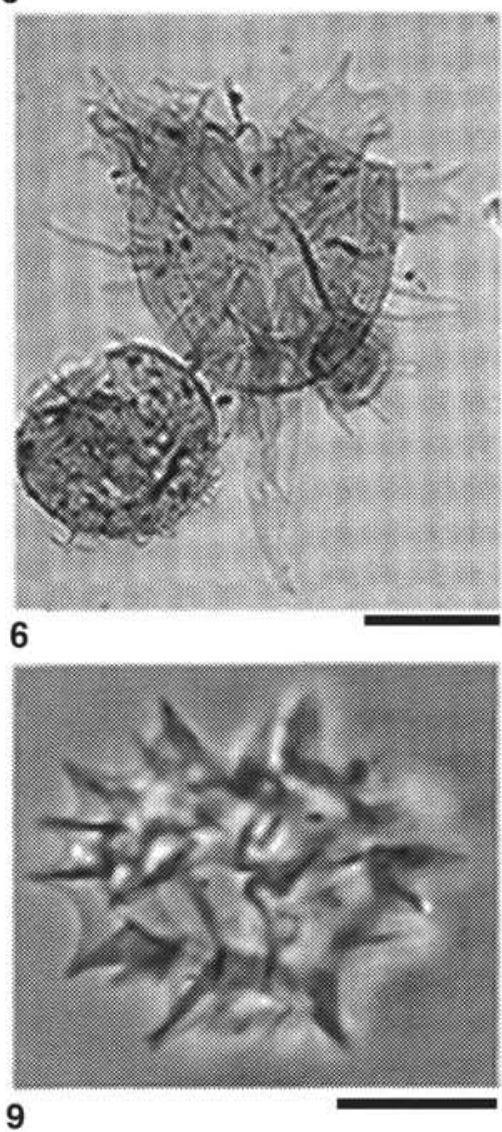

Plate 9. All scale bars $=25 \mu \mathrm{m}$, except where noted. 1. Histiocysta sp.; 913B-24R-2, $77-79 \mathrm{~cm} ; 464.27$ mbsf; N40-3; PH. 2. Homotryblium tenuispinosum; scale $\mathrm{bar}=50 \mu \mathrm{m}$; 913B-20R-2, 98-102 cm; $425.98 \mathrm{mbsf}$; G34-4; PH. 3. Hystrichokolpoma rigaudiae; scale bar $=50 \mu \mathrm{m} ; 913 \mathrm{~B}-31 \mathrm{R}-1,99-104 \mathrm{~cm} ; 530.19 \mathrm{mbsf}$; O36-2; PH. 4. Impagidinium sp.; 913B-24R-5, 54-56 cm; 468.54 mbsf; V35; PH. 5. Impagidinium cf. I. velorum; 913B-24R-2, 77-79 cm; 464.27 mbsf; F33-4; PH. 6. Hystrichokolpoma cinctum; 913B-28R-1, 35-38 cm; 500.65 mbsf; L28-2; TR. 7. Impagidinium sp.; 913B-34R-2, $103-105 \mathrm{~cm} ; 560.68 \mathrm{mbsf}$; U36-3; PH. 8. Impagidinium velorum; 913B-25R-4, 88-90 cm; 476.98 mbsf; R39; TR. 9. Impagidinium cf. I. aculeatum; 913B-31R-1, 99-104 cm; 530.19 mbsf; Q29; PH. 


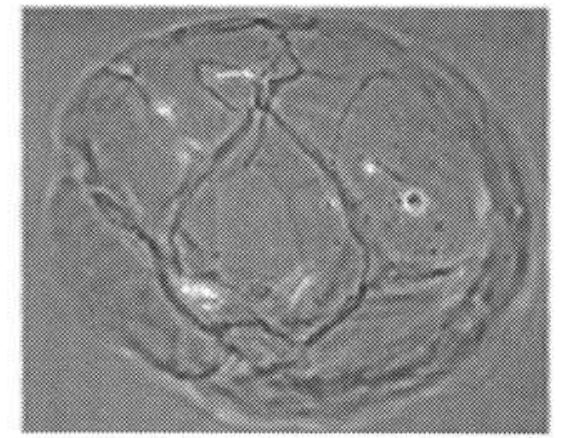

1

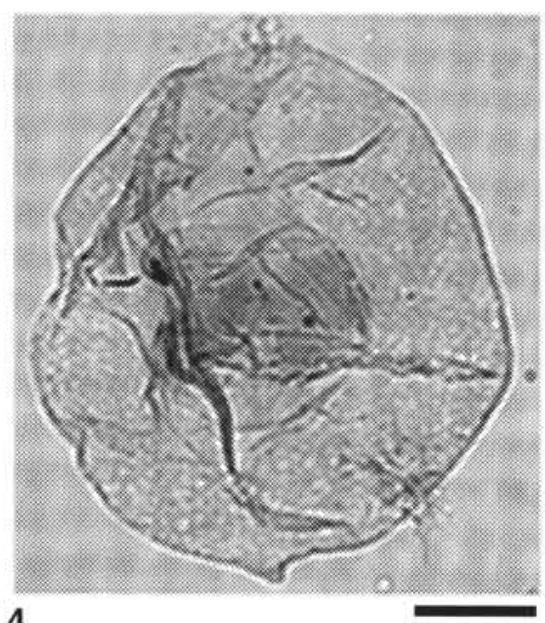

4

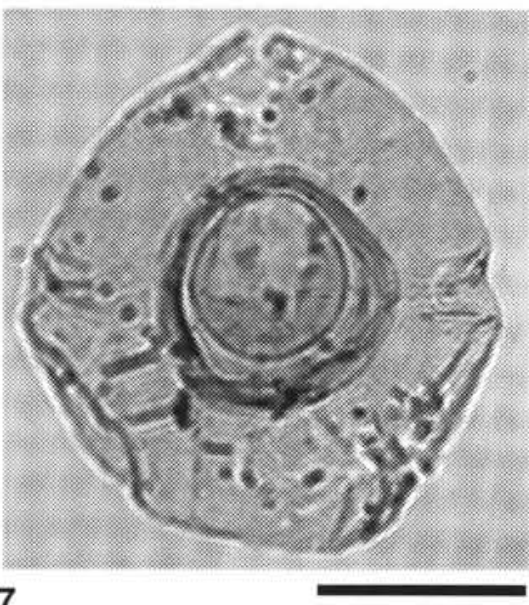

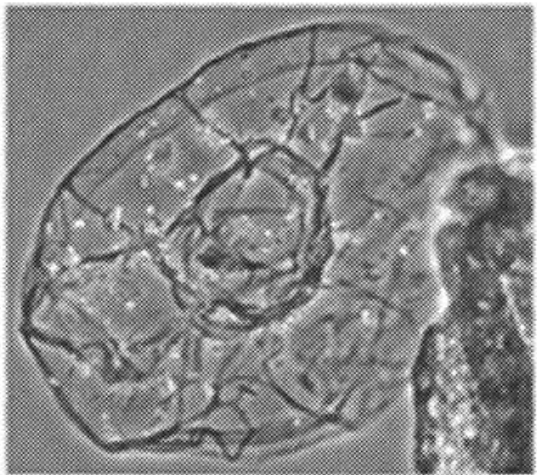

2

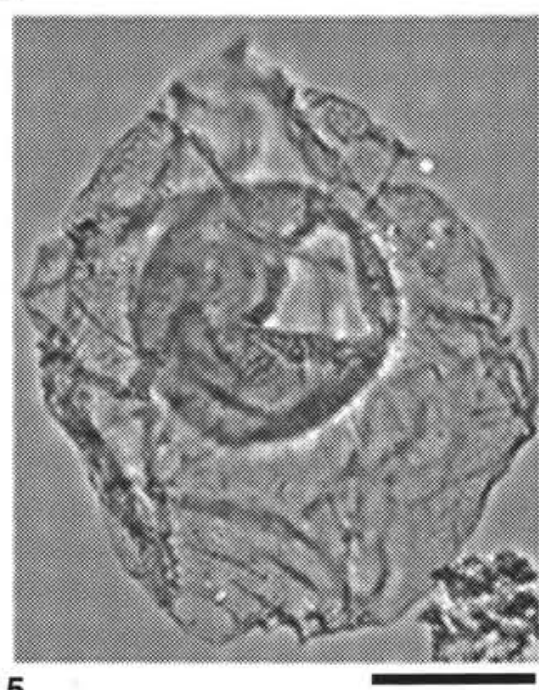

5

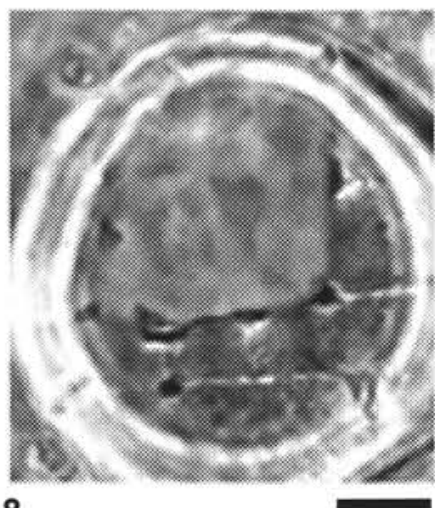

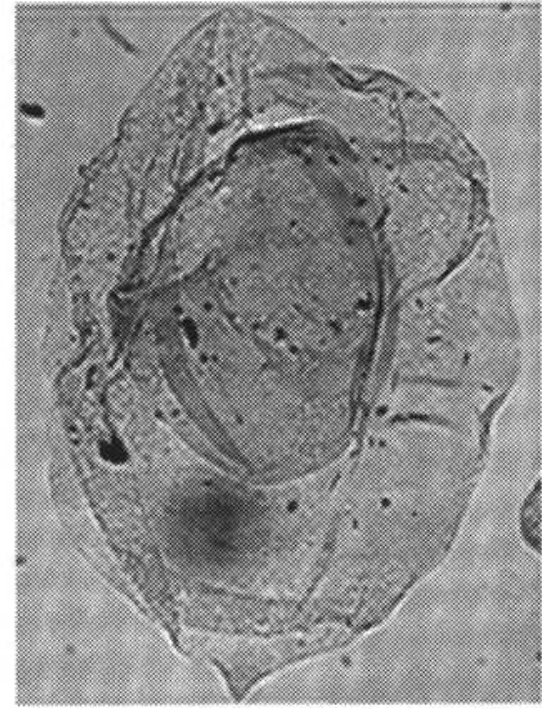

3

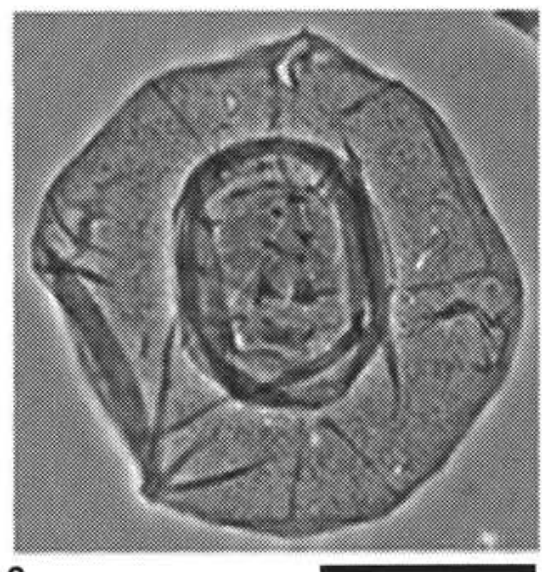

6

8

Plate 10. All scale bars $=50 \mu \mathrm{m}$, except where noted. 1. Thalassiphora delicata; scale bar $=25 \mu \mathrm{m} ; 913 \mathrm{~B}-29 \mathrm{R}-1,99-102 \mathrm{~cm} ; 510.89 \mathrm{mbsf} ; \mathrm{R} 43 ;$ PH. 2 . Thalassiphora delicata; 913B-34R-2, 103-105 cm; 560.68 mbsf; H30-3; PH. 3. Thalassiphora pelagica; 913B-28R-1, 35-38 cm; 500.65 mbsf; F42-4; TR. 4. Thalassiphora sp. 1; 913B-24R-2, 77-79 cm; 464.27 mbsf; S37; TR. 5. Thalassiphora sp. 2; 913B-29R-1, 99-102 cm; 510.89 mbsf; N29-3; PH. 6. Species 7; 913B-

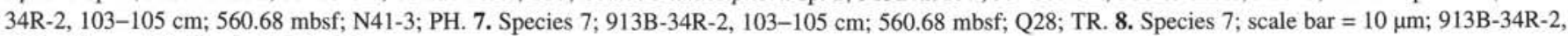
$103-105 \mathrm{~cm} ; 560.68 \mathrm{mbsf} ;$ Q28; PH. 


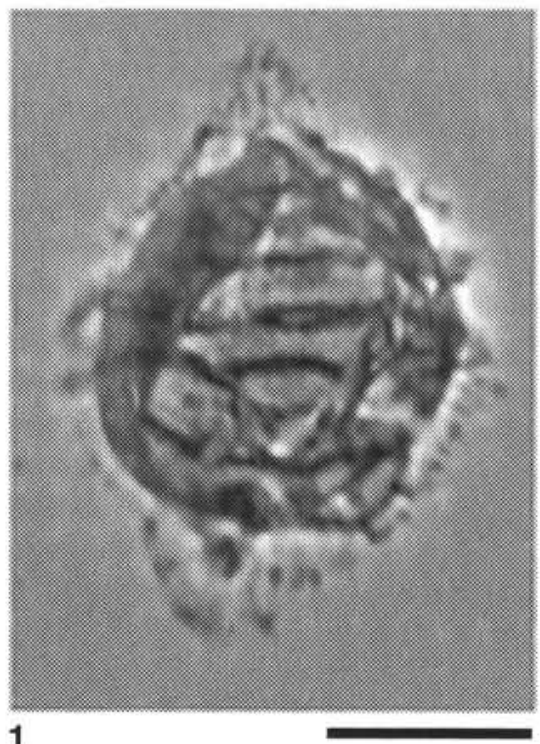

1

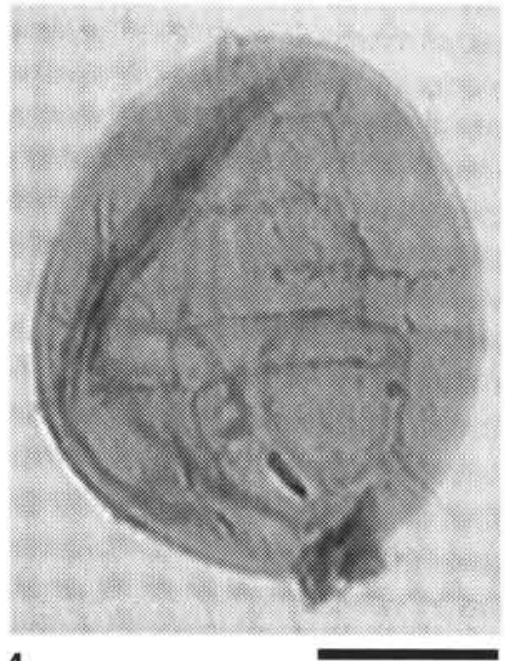

4

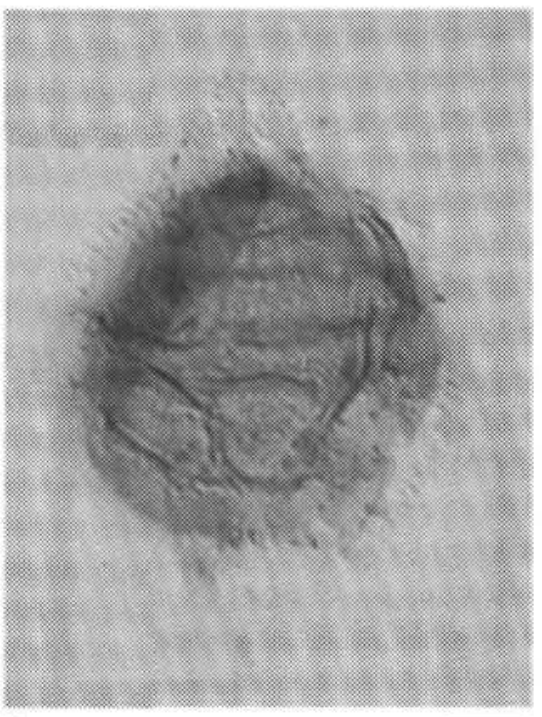

2

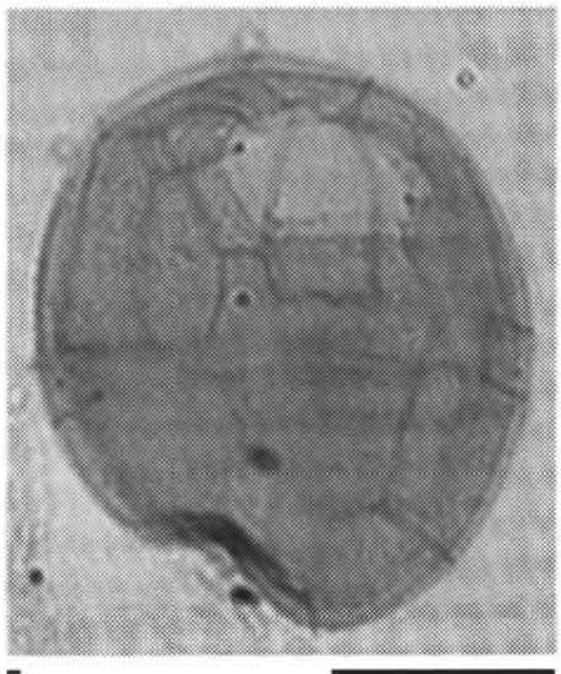

5

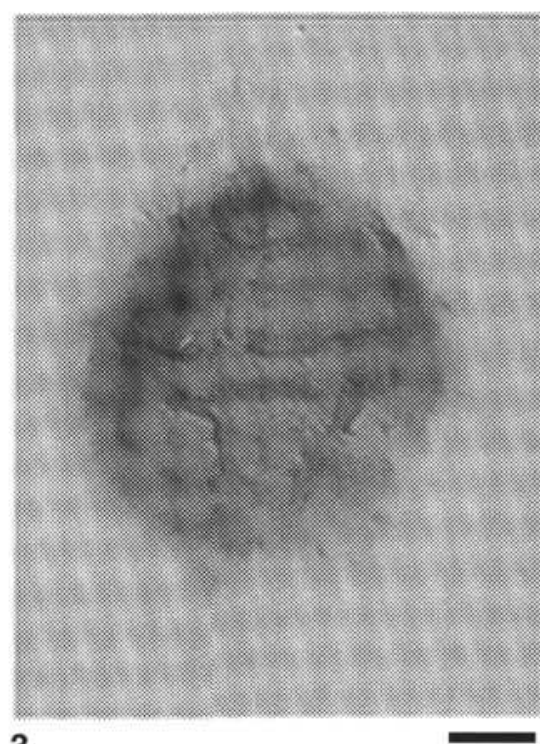

3

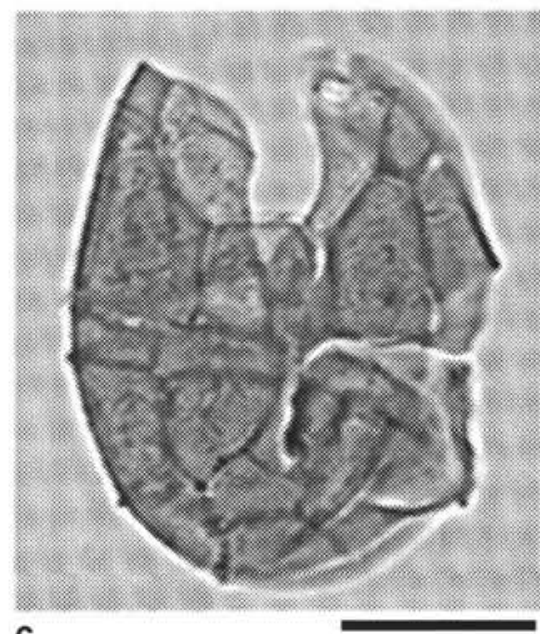

6

Plate 11. All scale bars $=25 \mu \mathrm{m}$, except where noted. 1. Phthanoperidinium alectrolophum; 913B-33R-2, 100-104 cm; 550.90 mbsf; O31-1; PH. 2. Phthanoperidinium alectrolophum; scale bar $=10 \mu \mathrm{m} ; 913 \mathrm{~B}-33 \mathrm{R}-2,100-104 \mathrm{~cm} ; 550.90 \mathrm{mbsf} ;$ O31-1; IC. 3. Phthanoperidinium alectrolophum; scale bar $=10 \mu \mathrm{m} ; 913 \mathrm{~B}-$ 33R-2, 100-104 cm; 550.90 mbsf; O31-1; IC. 4. Phthanoperidinium amoenum; 913B-25R-4, 88-90 cm; 476.98 mbsf; U43-1; TR. 5. Phthanoperidinium amoenum; 913B-25R-4, 88-90 cm; 476.98 mbsf; S31-4; TR. 6. Phthanoperidinium amoenum; 913B-25R-4. $88-90 \mathrm{~cm} ; 476.98 \mathrm{mbsf}$; J45-3; PH. 


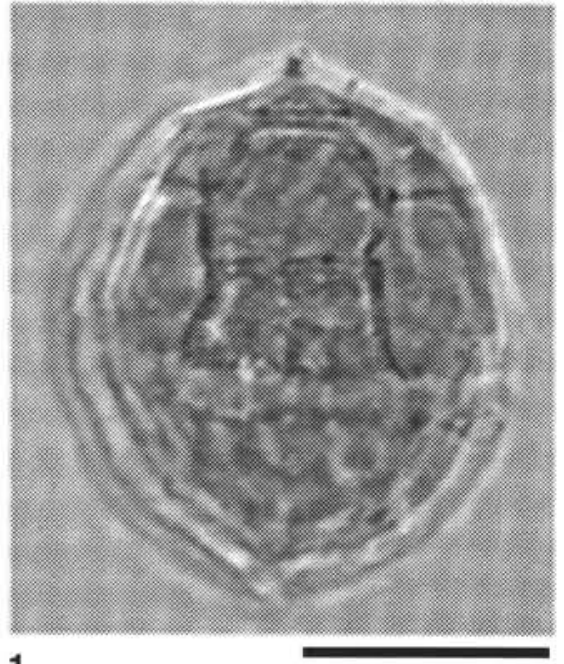

1

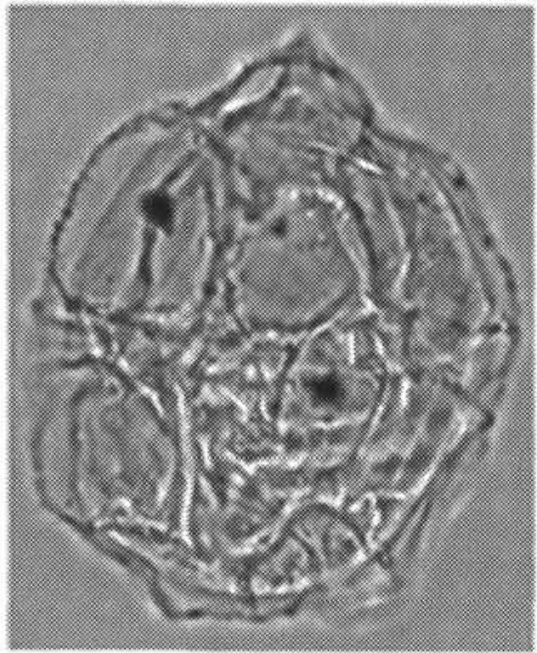

4

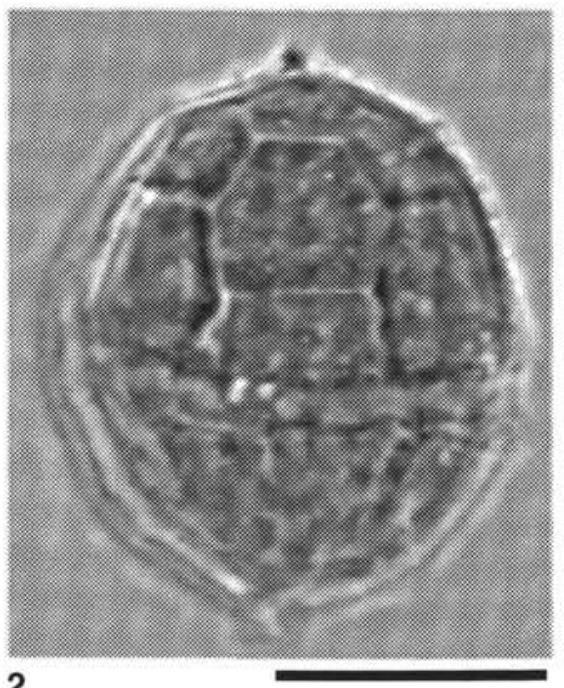

2

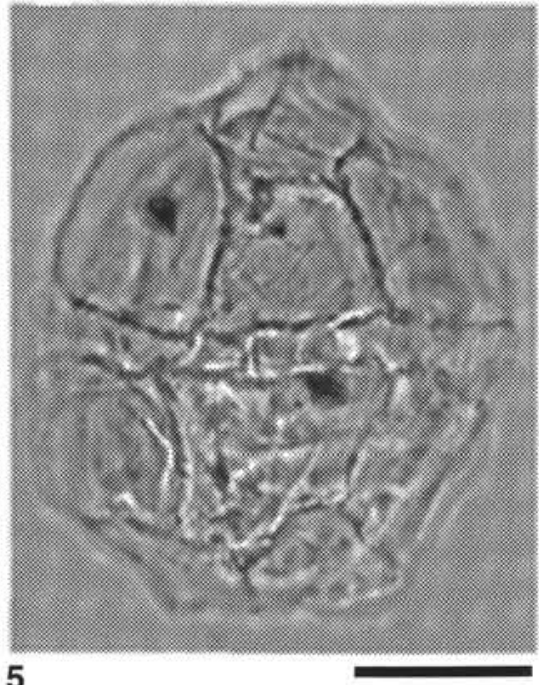

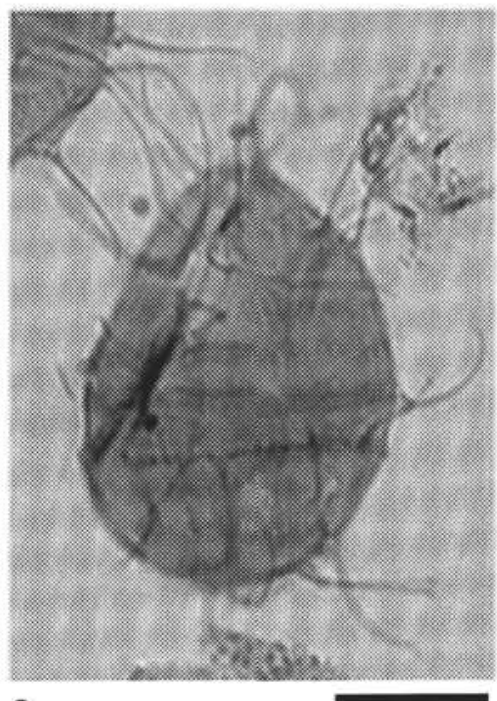

3

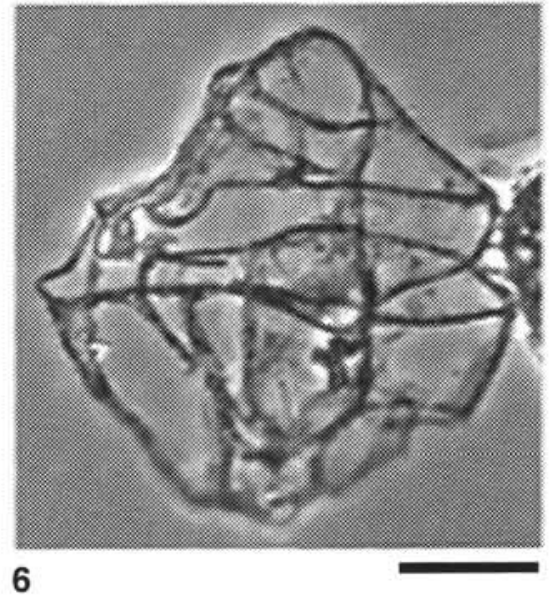

6

Plate 12. All scale bars $=25 \mu \mathrm{m}$. 1. Phthanoperidinium $\mathrm{cf}$. $P$. eocenicum; $913 \mathrm{~B}-24 \mathrm{R}-2,77-79 \mathrm{~cm} ; 464.27 \mathrm{mbsf} ; \mathrm{G} 31 ; \mathrm{PH}$. 2. Phthanoperidinium cf. P.? eocenicum; 913B-24R-2, 77-79 cm; 464.27 mbsf; G31; PH. 3. Phthanoperidinium comatum; 913B-25R-4, 88-90 cm; 476.98 mbsf; V33; TR. 4. Phthanoperidinium distinctum; 913B-30R-2, 97-101 cm; 521.97 mbsf; K32-4; PH. 5. Phthanoperidinium distinctum; 913B-30R-2, 97-101 cm; 521.97 mbsf; K32-4; PH. 6. Phthanoperidinium distinctum; 913B-30R-2, 97-101 cm; 521.97 mbsf; 134-4; PH. 


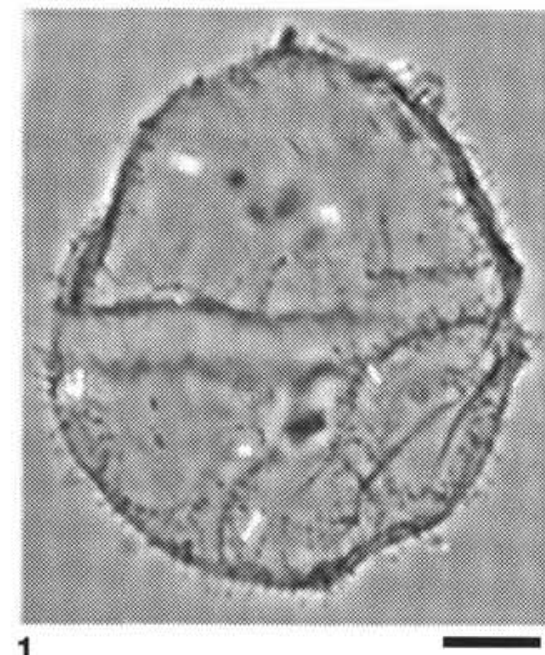

1

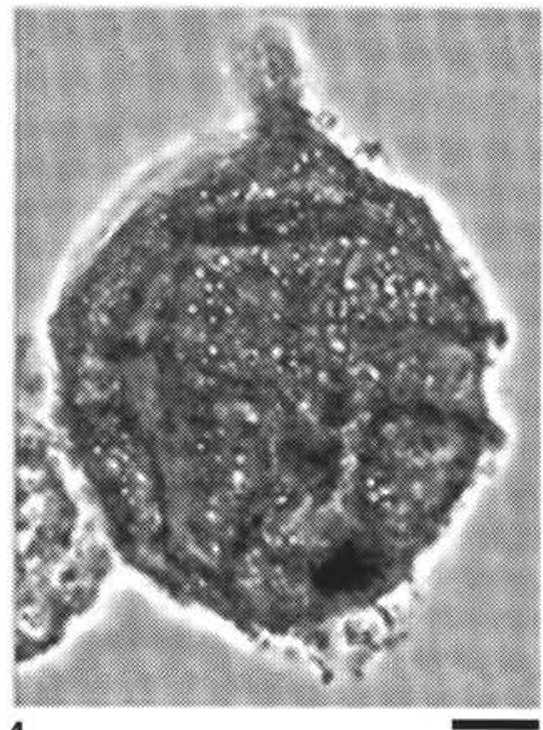

4

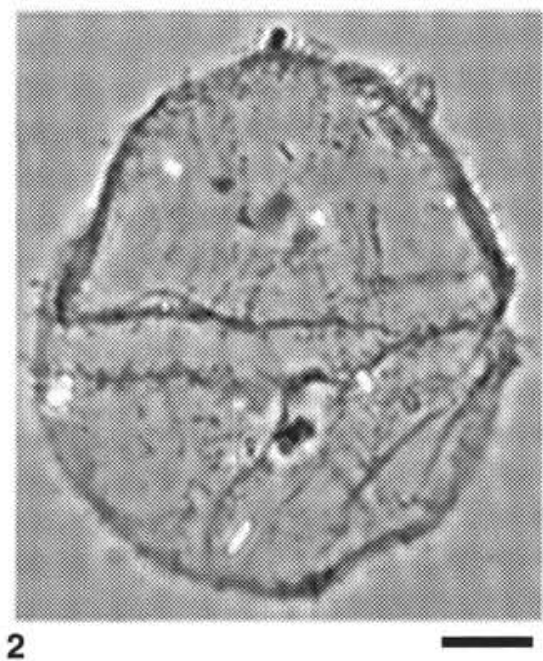

2

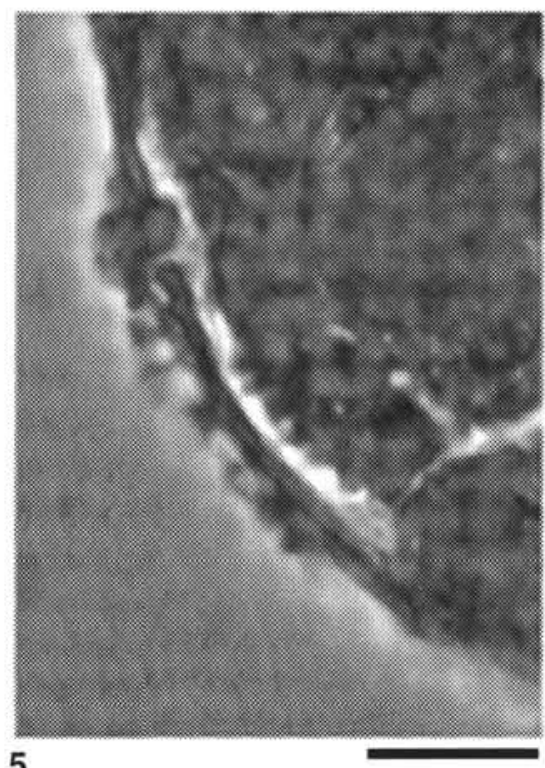

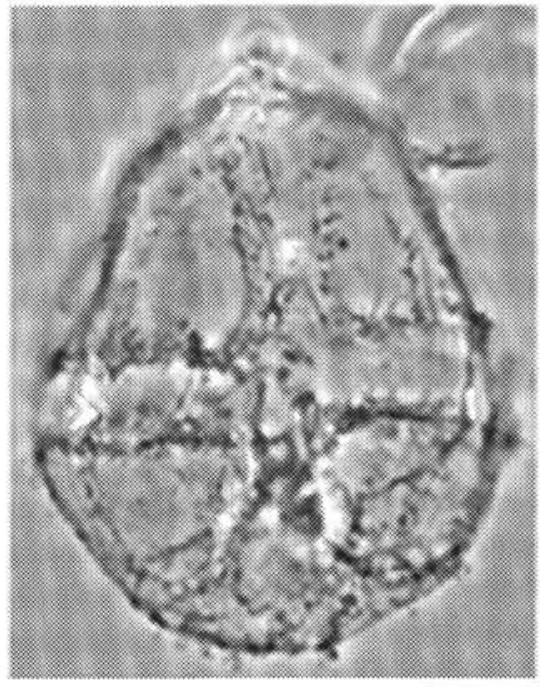

3

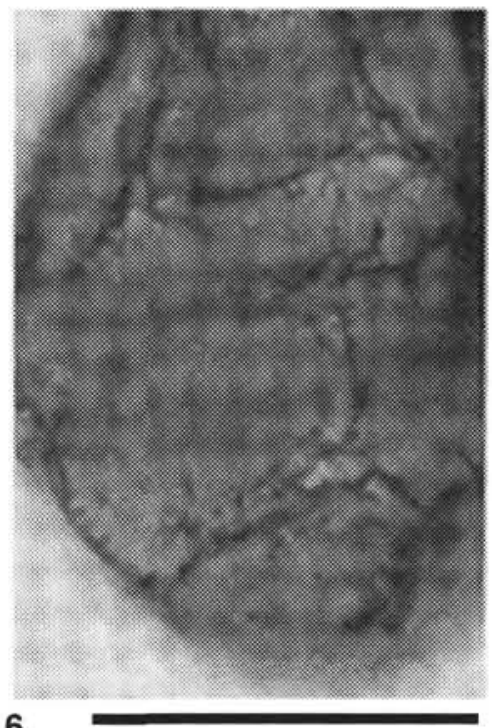

Plate 13. All scale bars $=10 \mu \mathrm{m}$, except where noted. 1. Phthanoperidinium echinatum; 913B-30R-2, 97-101 cm; 521.97 mbsf; K33; PH. 2. Phthanoperidinium echinatum; 913B-30R-2, 97-101 cm; 521.97 mbsf; K33; PH. 3. Phthanoperidinium echinatum; 913B-33R-2, $100-104$ cm; 550.90 mbsf; J37; PH. 4. Phthanoperidinium filigranum; 913B-36R-3, 103-105 cm; 581.42 mbsf; F35-1; PH. 5. Phthanoperidinium filigranum; 913B-36R-3, 103-105 cm; 581.42 mbsf; F31; PH. 6. Phthanoperidinium filigranum; scale bar $=25 \mu \mathrm{m} ; 913 \mathrm{~B}-36 \mathrm{R}-3,103-105 \mathrm{~cm} ; 581.42 \mathrm{mbsf} ; \mathrm{F} 31 ; \mathrm{PH}$. 


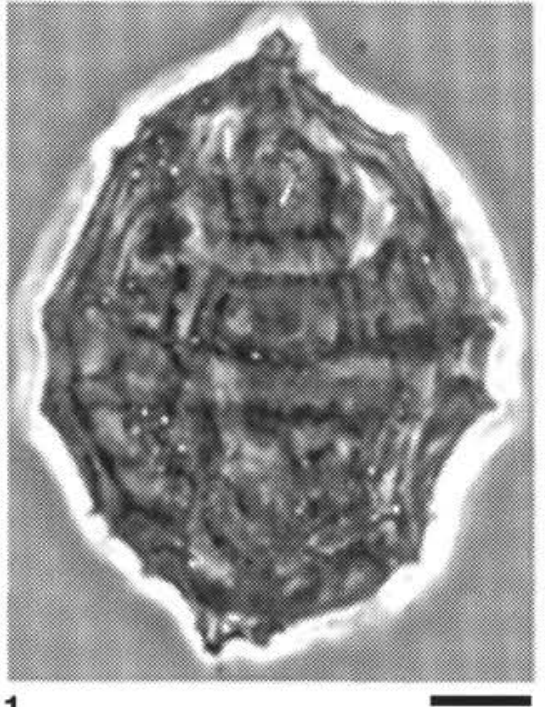

1

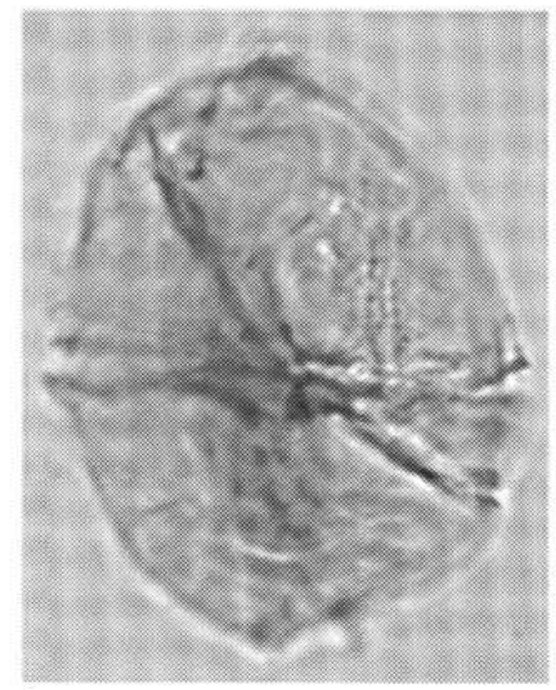

4

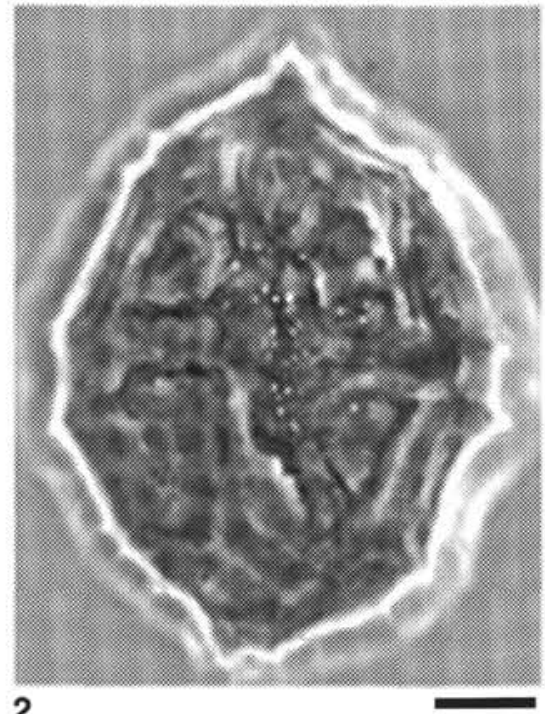

2

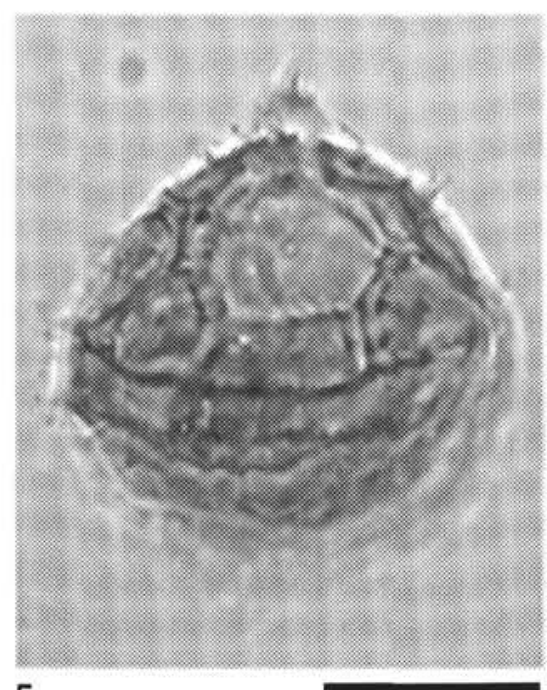

5

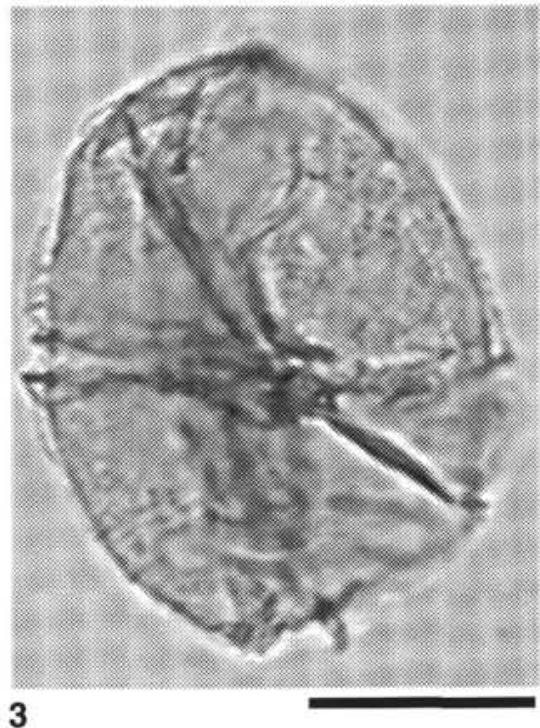

3

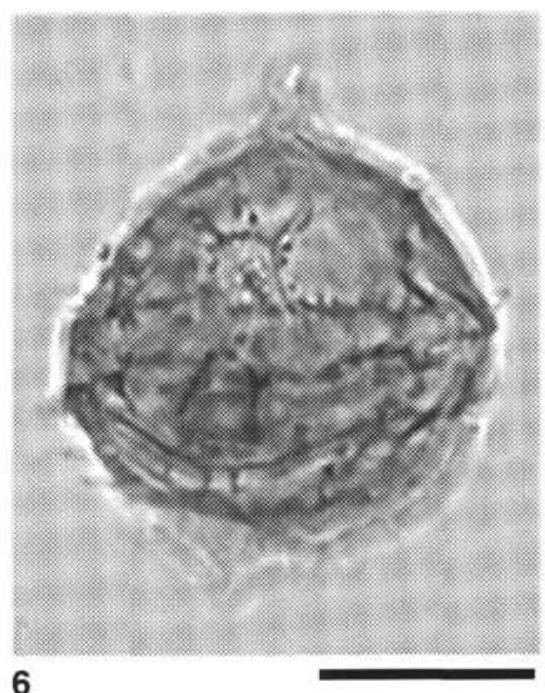

Plate 14. All scale bars $=25 \mu \mathrm{m}$, except where noted. 1. Phthanoperidinium geminatum; scale bar $=10 \mu \mathrm{m} ; 913 \mathrm{~B}-30 \mathrm{R}-2,97-101 \mathrm{~cm} ; 521.97 \mathrm{mbsf}$; D43-2; PH. 2. Phthanoperidinium geminatum; scale bar $=10 \mu \mathrm{m} ; 913 \mathrm{~B}-30 \mathrm{R}-2,97-101 \mathrm{~cm} ; 521.97 \mathrm{mbsf} ; \mathrm{D} 43-2 ; \mathrm{PH}$. 3. Phthanoperidinium cf. P. levimurum; $913 \mathrm{~B}-26 \mathrm{R}-6$, 100-102 cm; 489.60 mbsf; S38-4; PH. 4. Phthanoperidinium cf. P. levimurum; 913B-26R-6, 100-102 cm; 489.60 mbsf; S38-4; PH. 5. Phthanoperidinium multispinum; 913B-30R-2, 97-101 cm; 521.97 mbsf; K42-3; PH. 6. Phthanoperidinium multispinum; 913B-30R-2, 97-101 cm; 521.97 mbsf; K42-3; PH. 

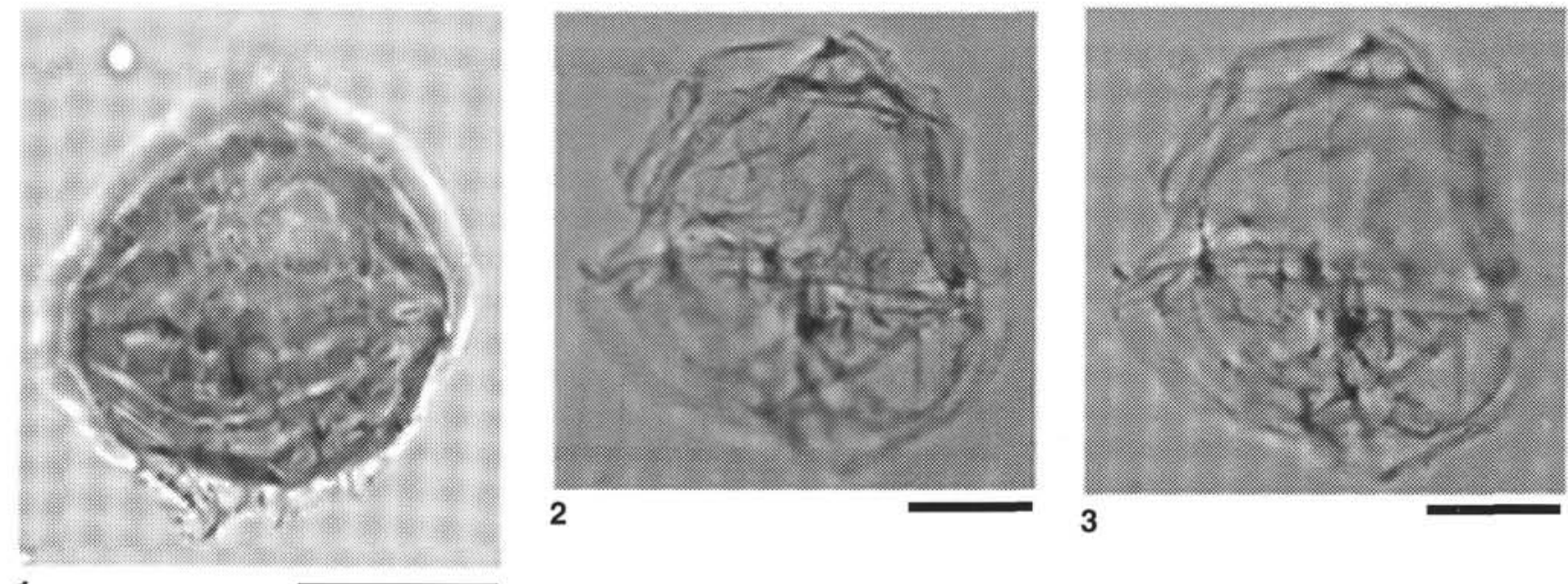

1
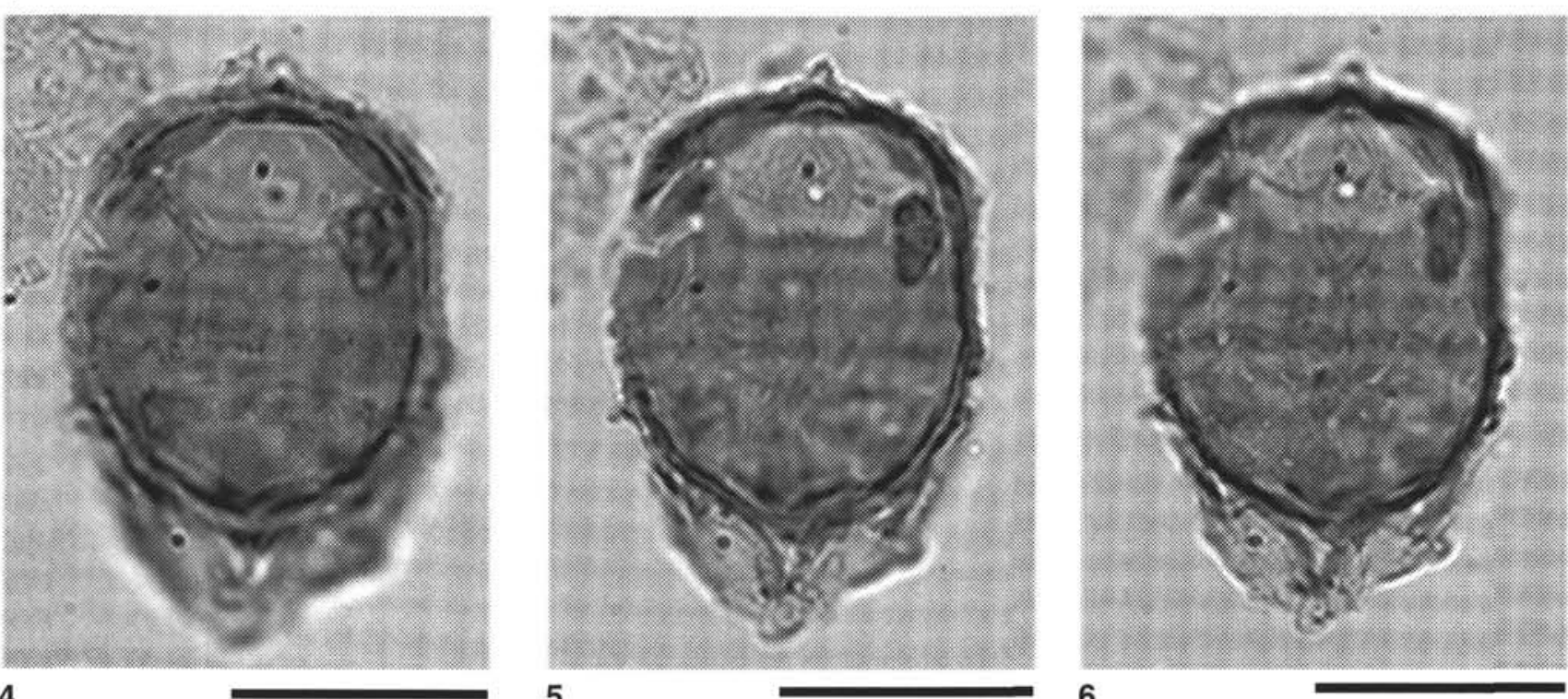

4

5

6

Plate 15. All scale bars $=25 \mu \mathrm{m}$. 1. Phthanoperidinium multispinum; 913B-30R-2, 97-101 cm; $521.97 \mathrm{mbsf}$; K42-3; PH. 2. Phthanoperidinium powellii; $913 \mathrm{~B}-$ 24R-5, 54-56 cm; 468.54 mbsf; G42; PH. 3. Phthanoperidinium powellii; 913B-24R-5, 54-56 cm; 468.54 mbsf; G42; PH. 4. Phthanoperidinium resistente; 913B-25R-2, 110-113 cm; 474.20 mbsf; F33; TR. 5. Phthanoperidinium resistente; 913B-25R-2, 110-113 cm; 474.20 mbsf; F33; TR. 6. Phthanoperidinium resistente; 913B-25R-2, 110-113 cm; 474.20 mbsf; F33; TR. 

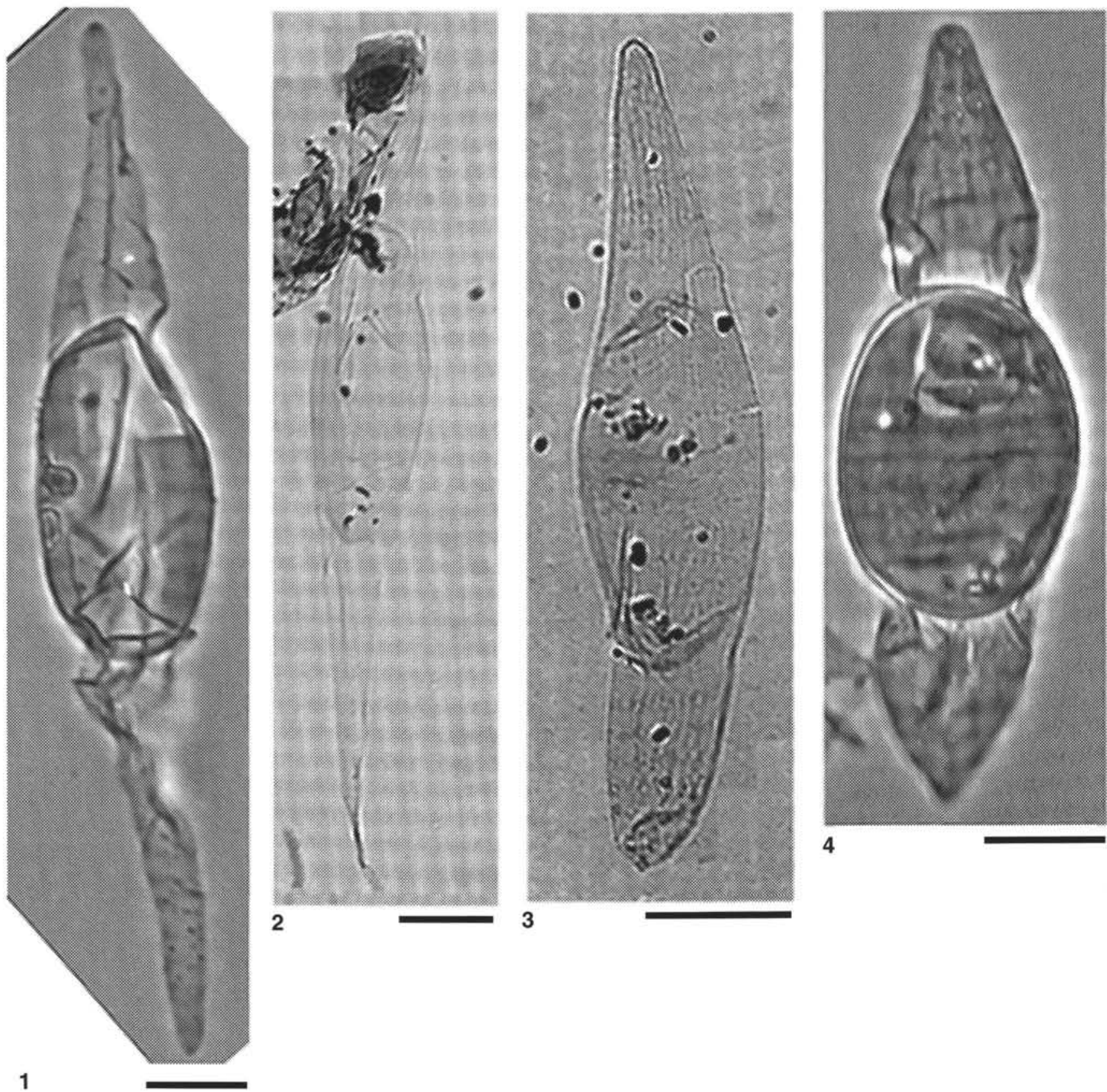

3

Plate 16. All scale bars $=25 \mu \mathrm{m}$. 1. Palaeocystodinium golzowense; $913 \mathrm{~B}-31 \mathrm{R}-1,99-104 \mathrm{~cm} ; 530.19 \mathrm{mbsf} ;$ N40-2; PH. 2. Palaeocystodinium sp. 1; $913 \mathrm{~B}-28 \mathrm{R}-$ 1, 35-38 cm; 500.65 mbsf; W30-2; TR. 3. Svalbardella cooksoniae; 913B-25R-6; 95-97 cm; 480.05 mbsf; P34-4; TR. 4. Svalbardella cf. S. cooksoniae; $913 \mathrm{~B}-$ 30R-2, 97-101 cm; 521.97 mbsf; M36-4; PH. 


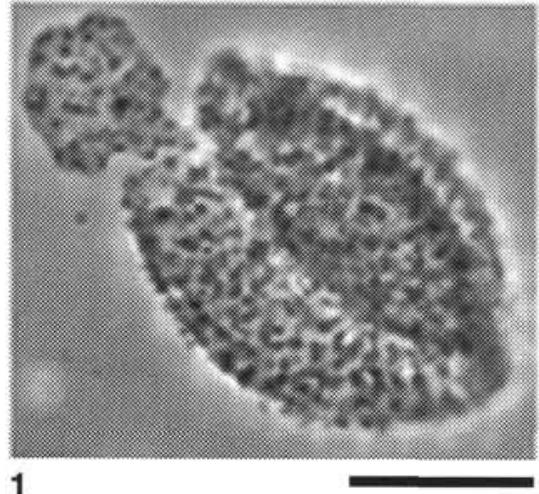

1

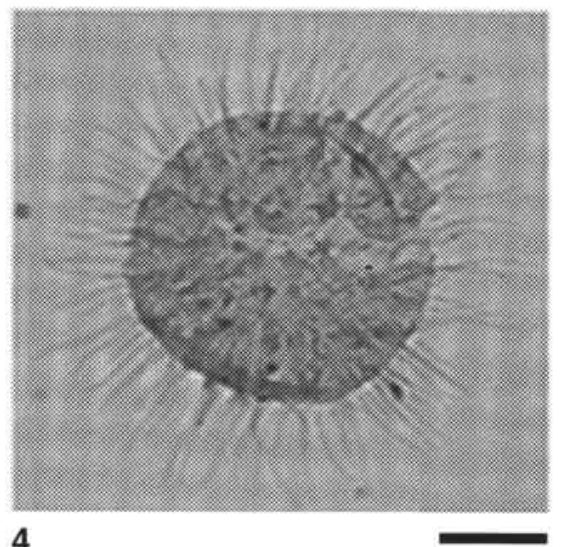

4

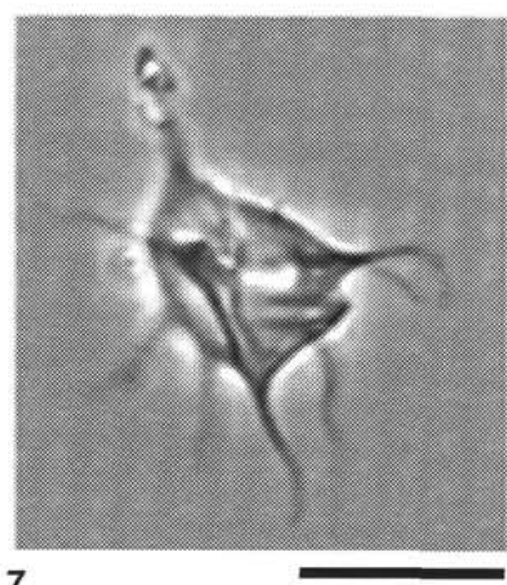

7

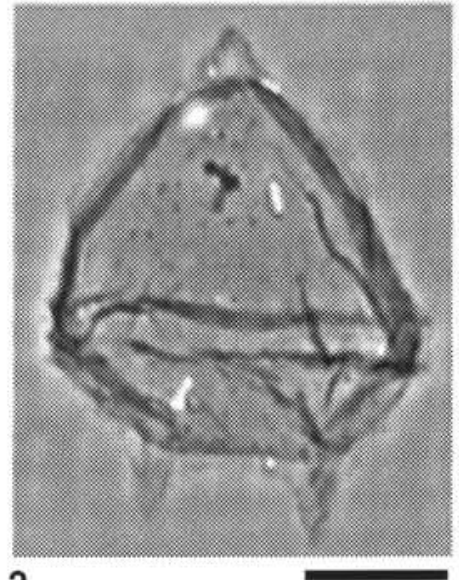

2

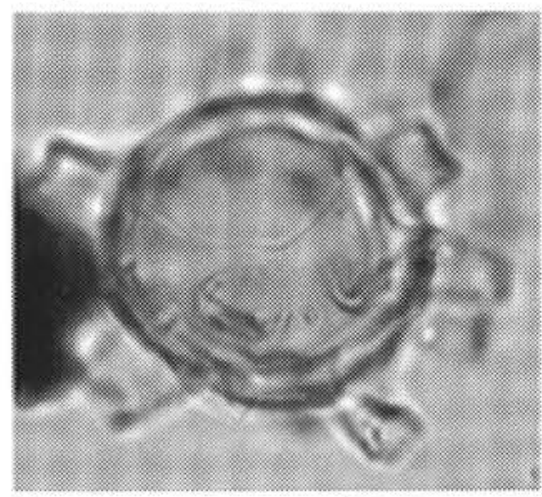

5

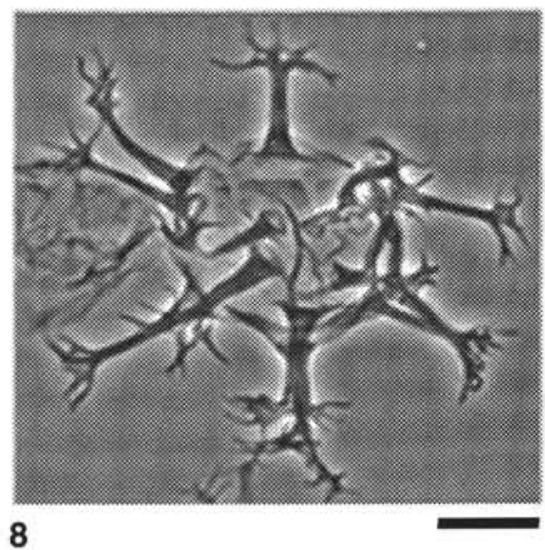

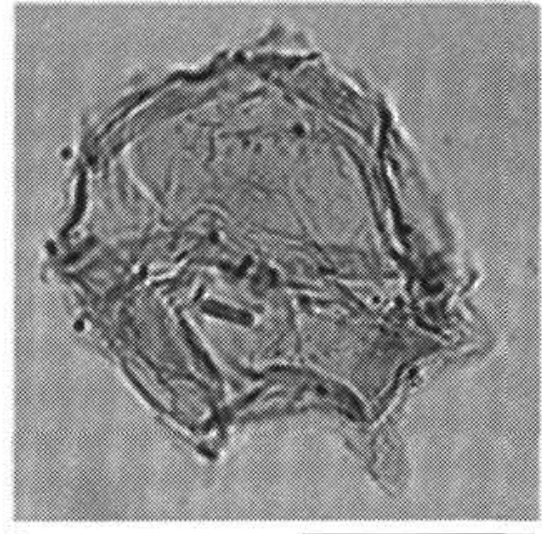

3

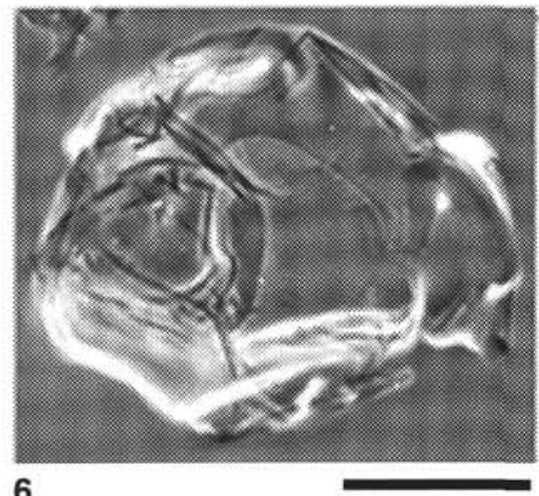

6

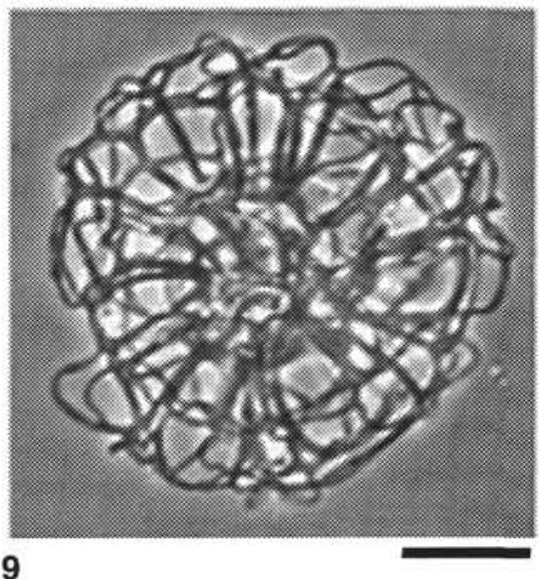

Plate 17. All scale bars $=25 \mu \mathrm{m}$, except where noted. 1. Kallosphaeridium? sp.1; 913B-25R-4, 88-90 cm; 476.98 mbsf; R44; PH. 2. Lentinia serrata; $913 \mathrm{~B}-$ 33R-2, 100-104 cm; 550.90 mbsf; M37-4; PH. 3. Lentinia sp. 1; 913B-26R-2, 100-102 cm; 483.60 mbsf; X36-2; TR. 4. Lingulodinium machaerophorum; 913B-24R-4, 68-70 cm; 467.18 mbsf; F40; TR. 5. Litosphaeridium sp.; 913B-24R-2, 77-79 cm; 464.27 mbsf; Q31-3; TR. 6. Lophocysta sp. 1; scale bar = 50 $\mu \mathrm{m}$; 913B-24R-2, 77-79 cm; 464.27 mbsf; W27-3; PH. 7. Micrhystridium sp. 1; 913B-28R-4, 35-38 cm; 505.15 mbsf; J34-4; PH. 8. Melitasphaeridium pseudorecurvatum; 913B-24R-2, 77-79 cm; 464.27 mbsf; W32-2; PH. 9. Nematosphaeropsis lemniscata; 913B-34R-2, 103-105 cm; 560.68 mbsf; V38-3; PH. 


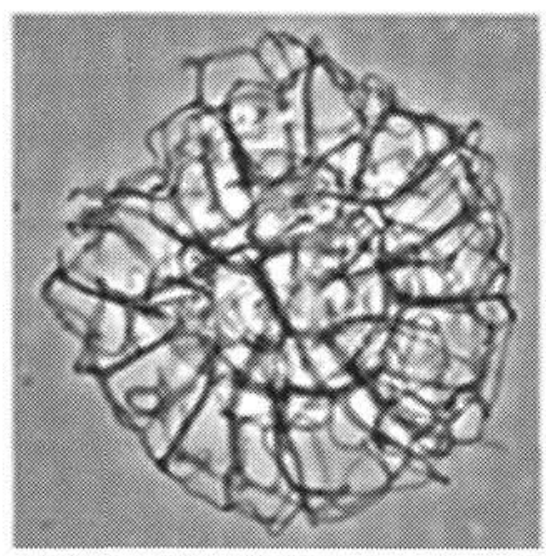

1

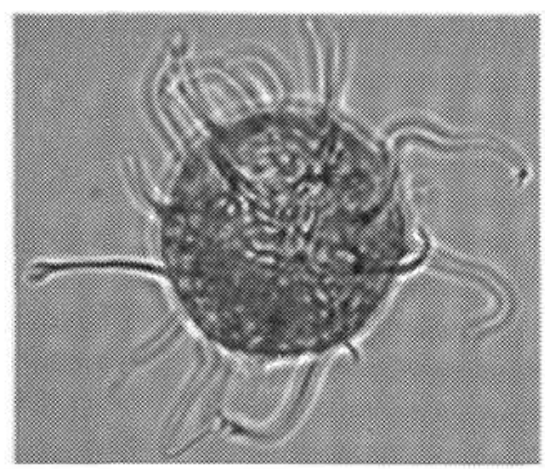

4

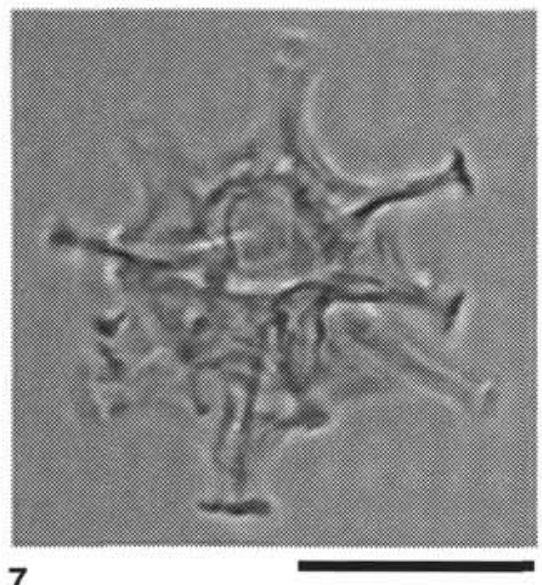

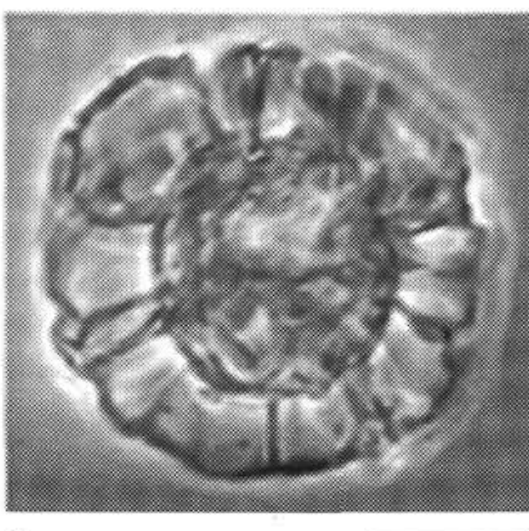

2

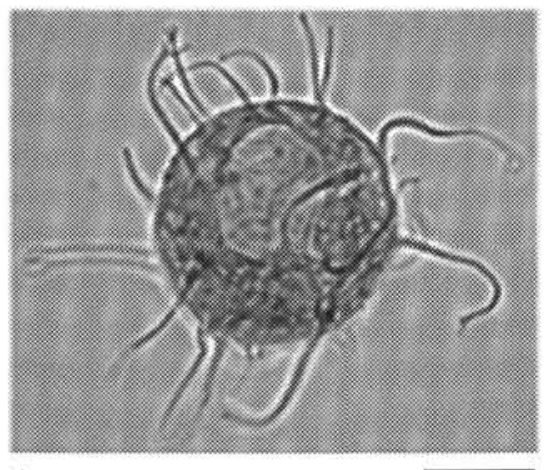

5

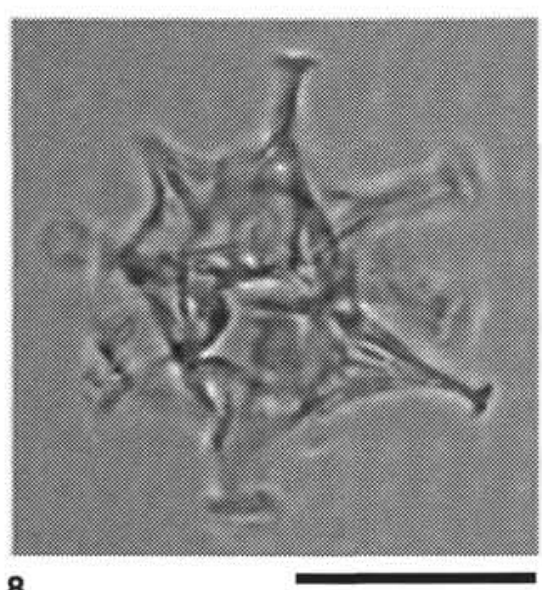

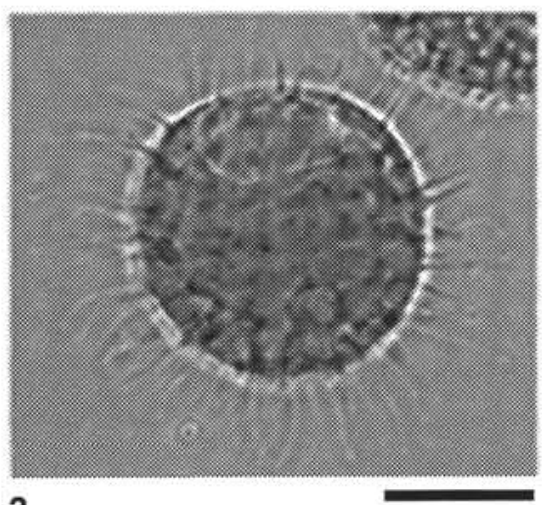

3
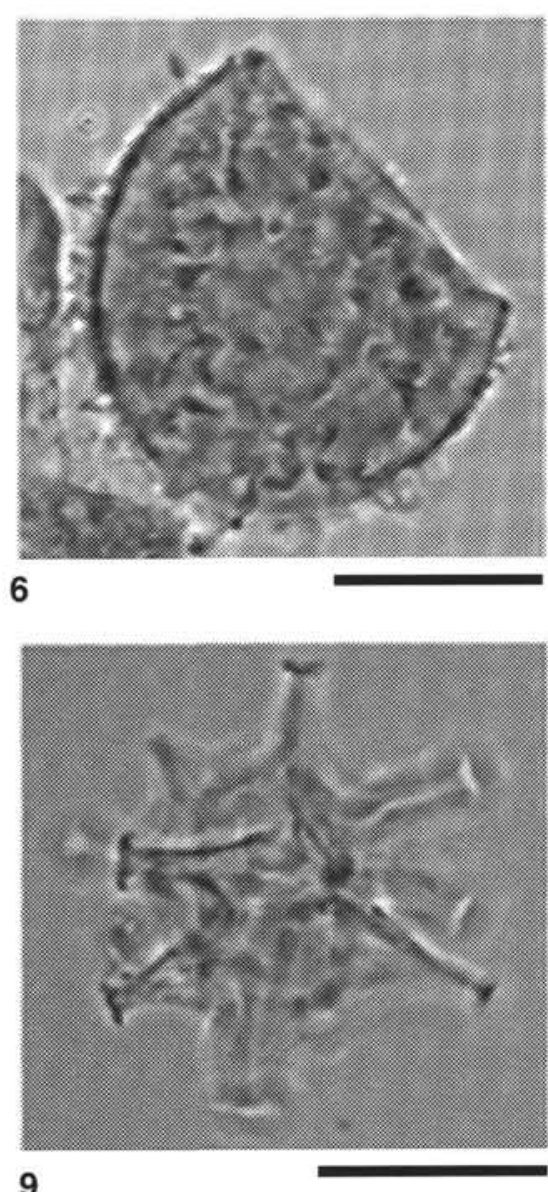

Plate 18. All scale bars $=25 \mu \mathrm{m}$. 1. Nematosphaeropsis sp. 1; 913B-24R-2, 77-79 cm; 464.27 mbsf; Q38-4; PH. 2. Nematosphaeropsis sp. 2; 913B-33R-2, 100$104 \mathrm{~cm} ; 550.90$ mbsf; J34; PH. 3. Operculodinium centrocarpum; 913B-26R-4, 100-102 cm; $486.60 \mathrm{mbsf}$; D41; PH. 4. Operculodinium divergens; 913B-29R1, 99-102 cm; 510.89 mbsf; D29-2; PH. 5. Operculodinium divergens; 913B-29R-1, 99-102 cm; 510.89 mbsf; D29-2; PH. 6. Operculodinium sp. 1; 913B-25R2, 110-113 cm; 474.20 mbsf; J32; PH. 7. Paucisphaeridium inversibuccinum; 913B-29R-1, 99-102 cm; 510.89 mbsf; E35; PH. 8. Paucisphaeridium inversibuccinum; 913B-29R-1, 99-102 cm; 510.89 mbsf; E35; PH. 9. Paucisphaeridium inversibuccinum; 913B-29R-1, 99-102 cm; 510.89 mbsf; E35; PH. 

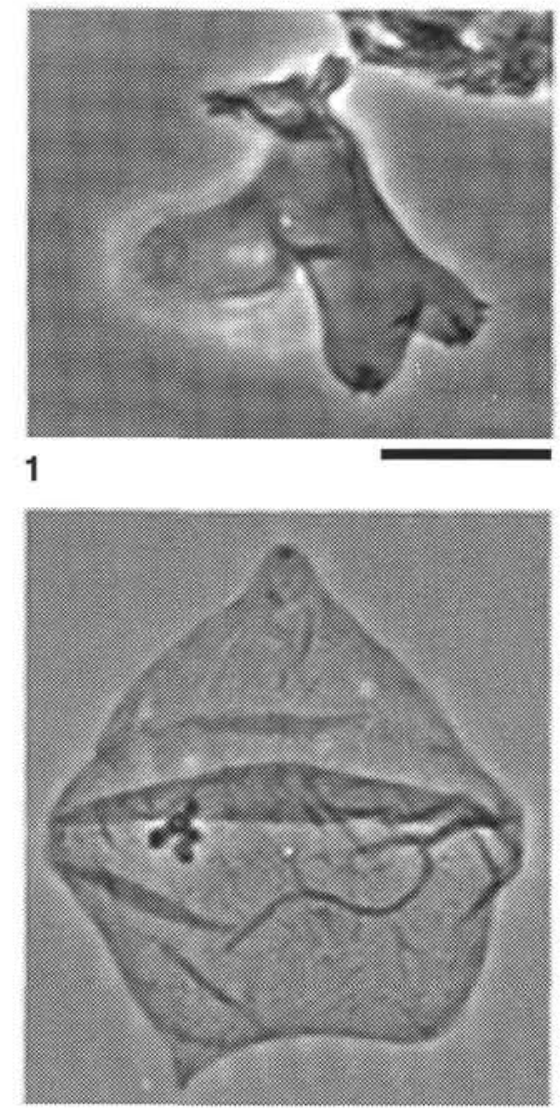

4

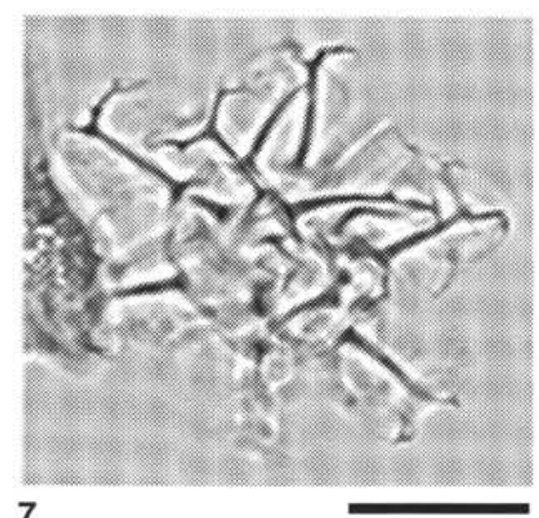

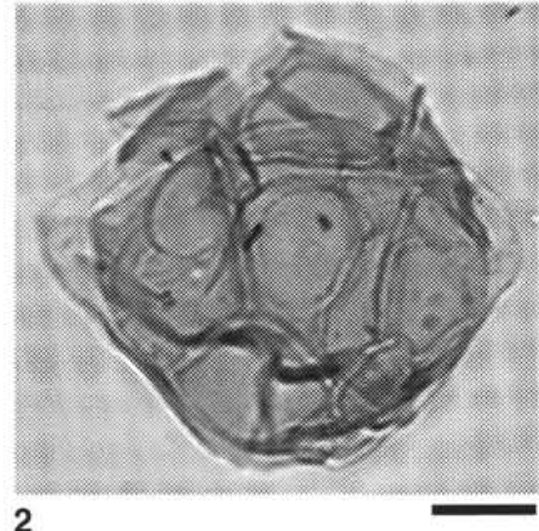

2
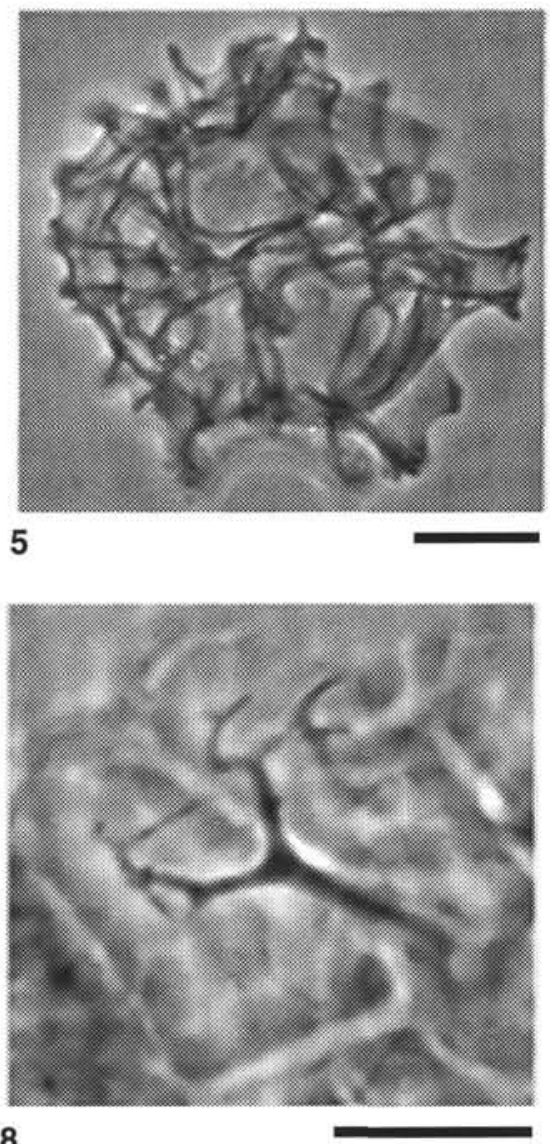

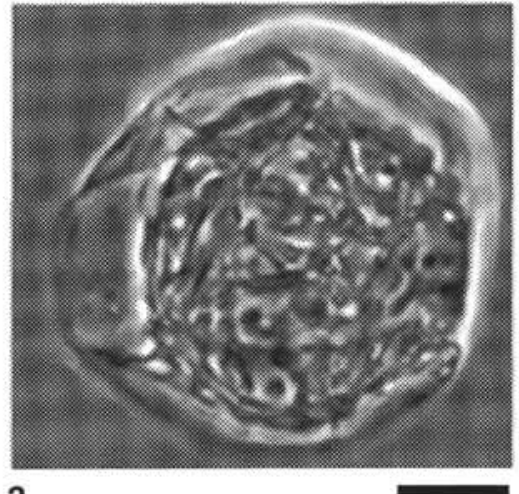

3
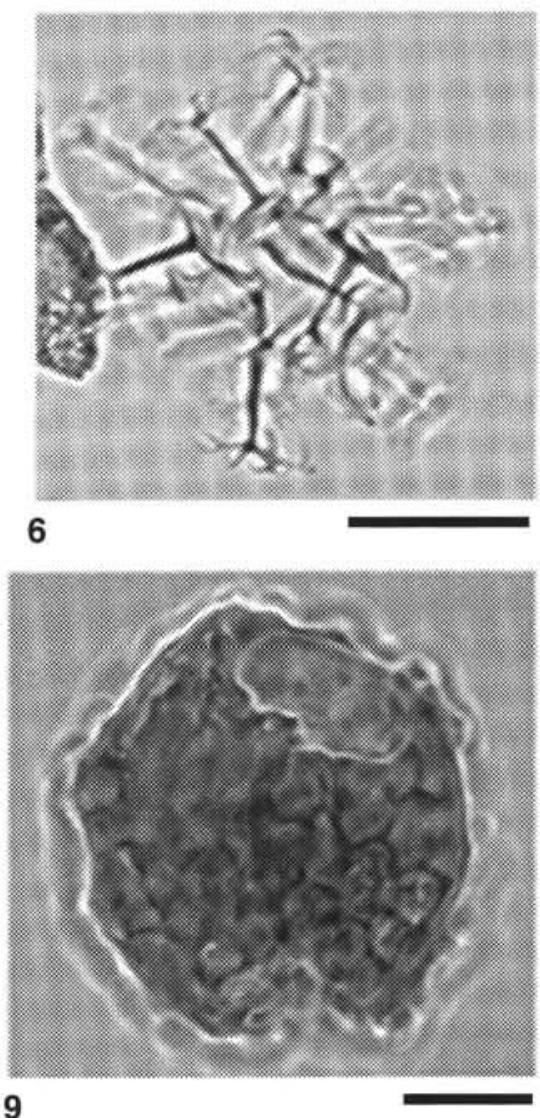

Plate 19. All scale bars $=25 \mu \mathrm{m}$, except where noted. 1. Paucilobimorpha triradiata; 913B-34R-2, 103-105 cm; 560.68 mbsf; S39; PH. 2. Pentadinium laticinctum laticinctum; 913B-20R-3, 95-99 cm; 427.45 mbsf; S42-1; TR. 3. Pentadinium laticinctum granulatum; 913B-24R-1, 68-70 cm; 462.68 mbsf; K42-4; PH. 4. Phelodinium sp.; 913B-21R-2, 97-101 cm; 435.57 mbsf; Q39-1; PH. 5. Pterodinium sp. 1; 913B-24R-5, 54-56 cm; 468.54 mbsf; K40-3; PH. 6. Reticulatosphaera actinocoronata; 913B-20R-2, 98-102 cm; 425.98 mbsf; J44-2; PH. 7. Reticulatosphaera actinocoronata; 913B-20R-2, 98-102 cm; 425.98 mbsf; J44-2; PH. 8. Reticulatosphaera actinocoronata; scale bar $=10 \mu \mathrm{m} ; 913 \mathrm{~B}-20 \mathrm{R}-2,98-102 \mathrm{~cm} ; 425.98 \mathrm{mbsf}$; J44-2; PH. 9. Samlandia chlamydophora; $913 \mathrm{~B}-$ 26R-4, 100-102 cm; 486.60 mbsf; U43-2; PH. 


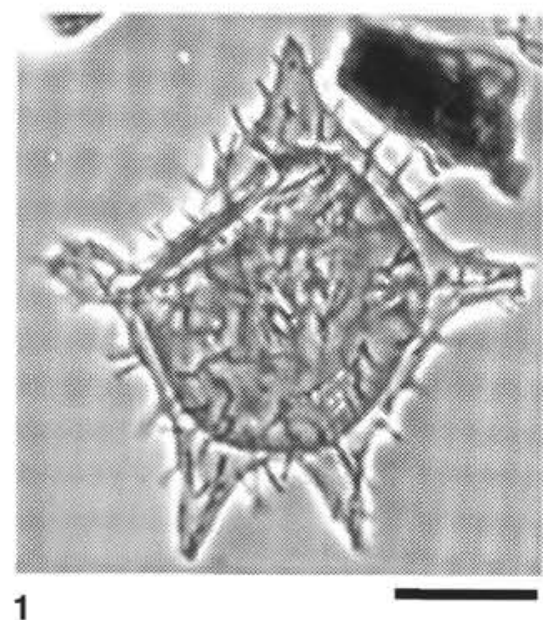

1

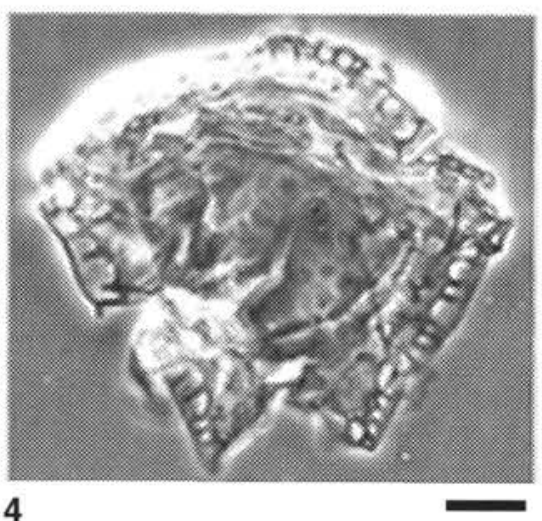

4

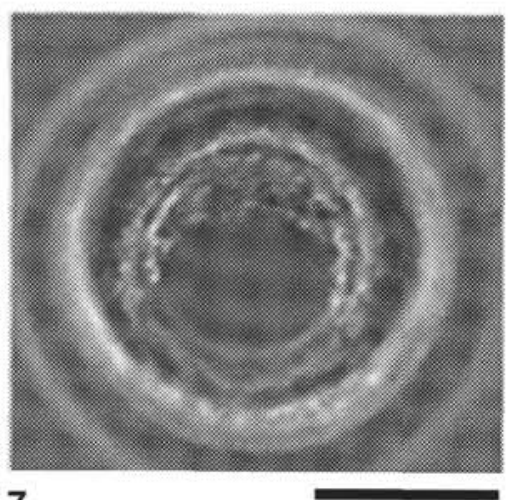

7

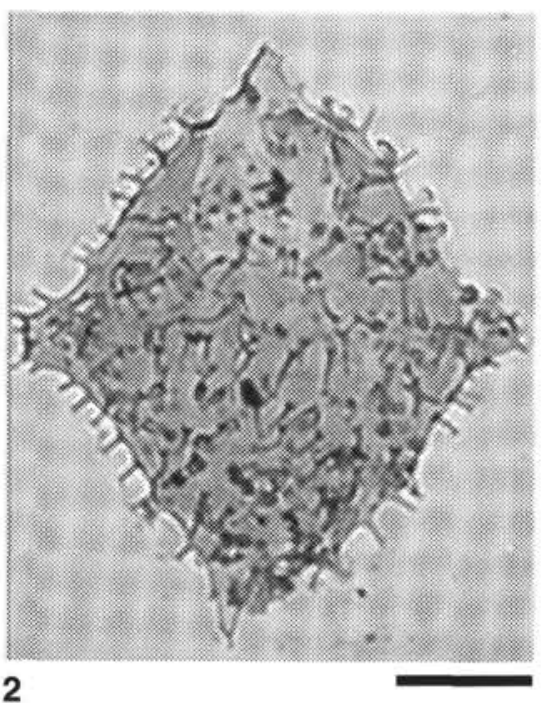

2

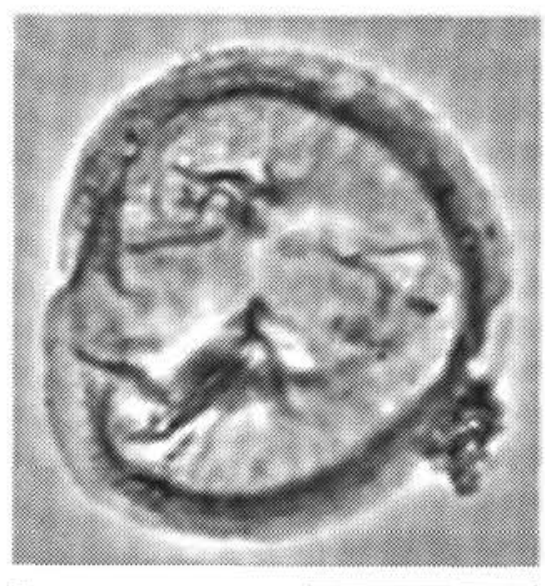

5

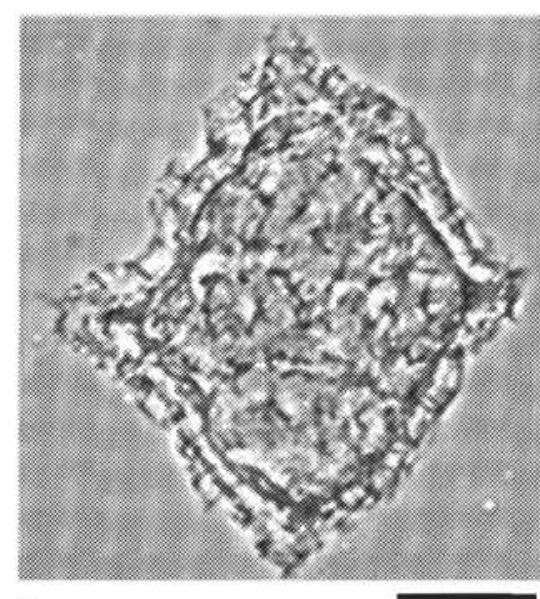

3

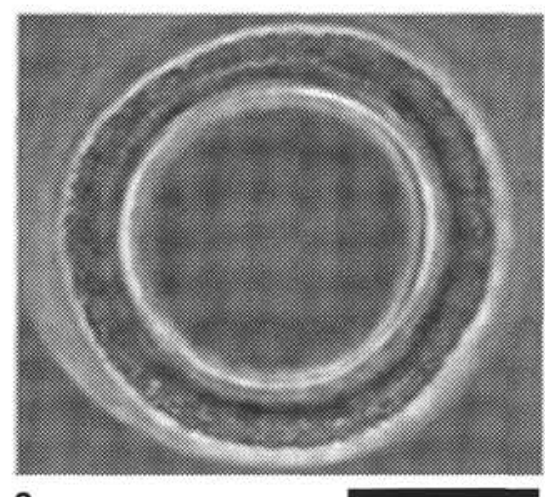

6

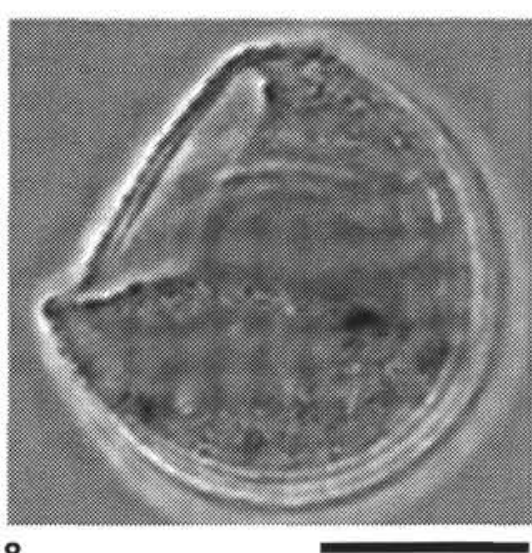

8

Plate 20. All scale bars $=25 \mu \mathrm{m}$, except where noted. 1. Wetzeliella articulata; scale bar $=50 \mu \mathrm{m} ; 913 \mathrm{~B}-20 \mathrm{R}-2,98-102 \mathrm{~cm} ; 425.98 \mathrm{mbsf} ; \mathrm{G} 39-1 ; \mathrm{PH}$. 2. Wetzeliella gochtii?; scale bar $=50 \mu \mathrm{m} ; 913 \mathrm{~B}-29 \mathrm{R}-2,99-102 \mathrm{~cm} ; 512.39$ mbsf; S40-1; TR. 3. Charlesdowniea sp.; scale bar $=50 \mu \mathrm{m} ; 913 \mathrm{~B}-26 \mathrm{R}-2,100-102 \mathrm{~cm}$; 483.60 mbsf; M31-2; PH. 4. Charlesdowniea sp.; 913B-25R-6, 100-102 cm; 480.05 mbsf; L41-2; PH. 5. Selenopemphix nephroides; 913B-29R-2, 99-102 cm; 512.39 mbsf; K37-2; PH. 6. Tectatodinium grande; 913B-24R-2, 77-79 cm; 464.27 mbsf; X34-3; PH. 7. Tectatodinium grande; 913B-24R-2, 77-79 cm; 464.27 mbsf; X34-3; PH. 8. Tectatodinium sp. 1; 913B-24R-2, 77-79 cm; 464.27 mbsf; H26; PH. 

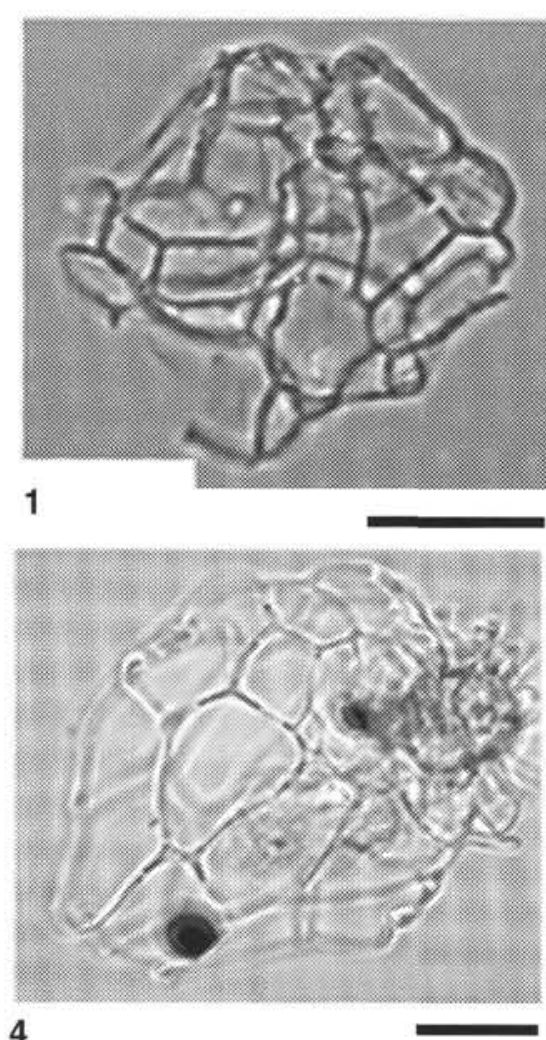

4

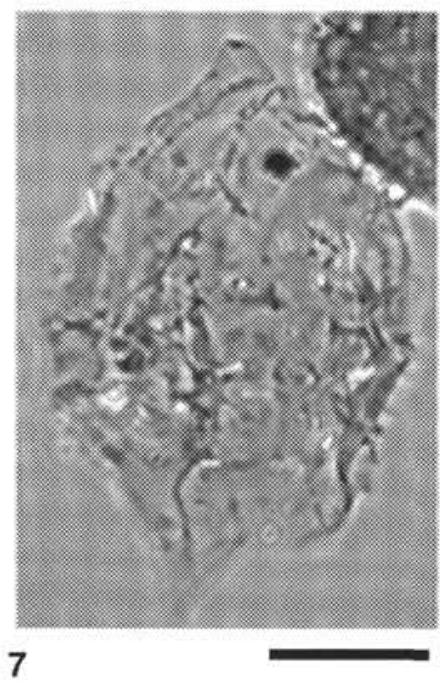

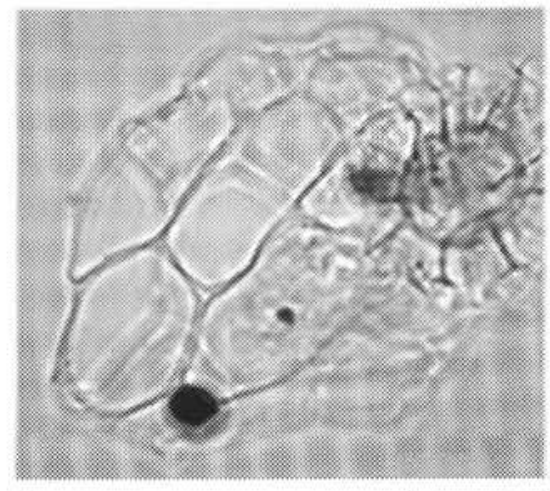

2

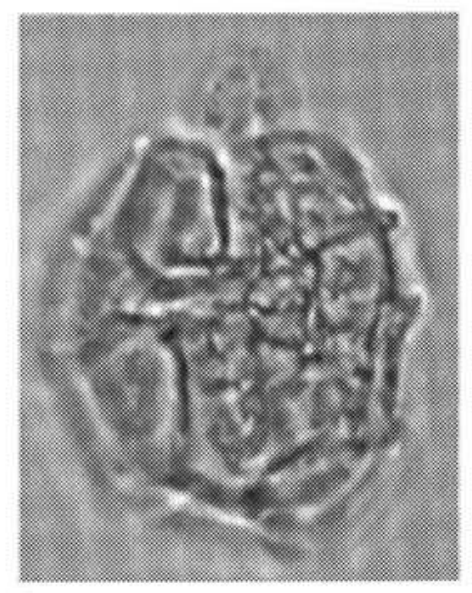

5

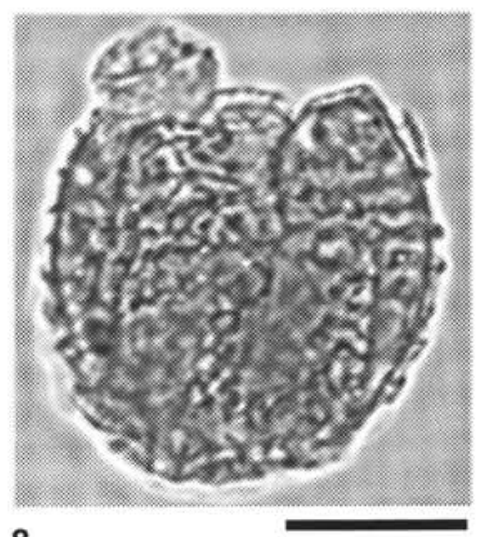

8
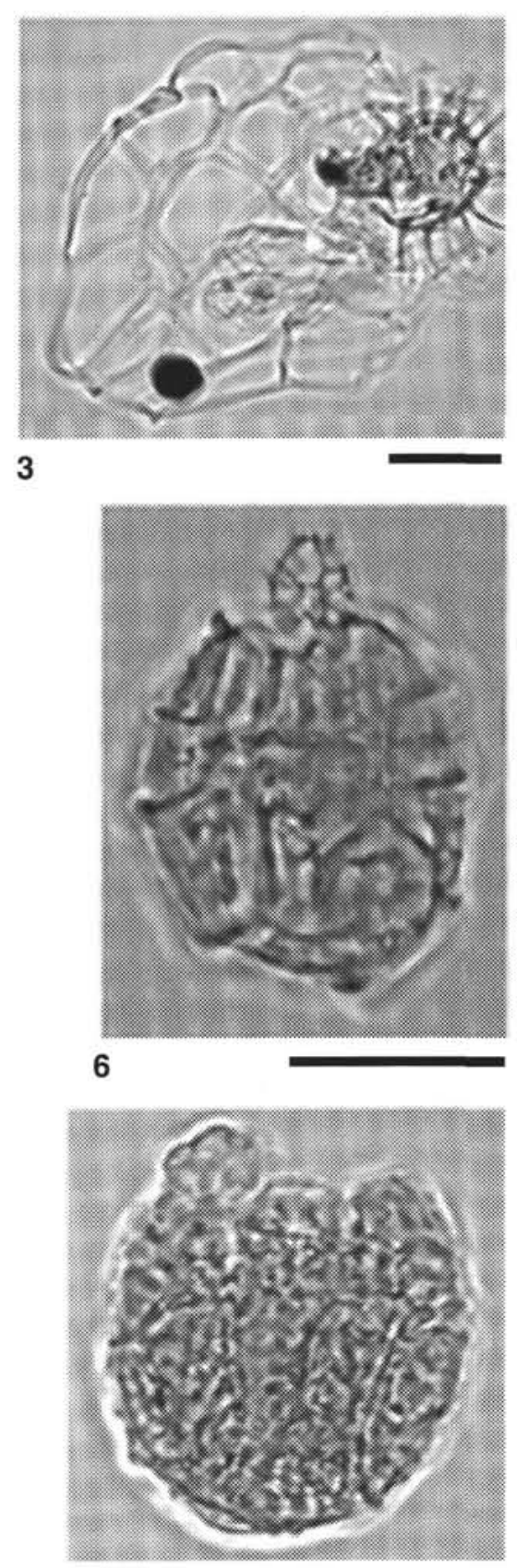

9

Plate 21. All scale bars $=25 \mu \mathrm{m}$. 1. Species 1; 913B-26R-4, 100-102 cm; $486.60 \mathrm{mbsf}$; G29-4; PH. 2. Species 1; 913B-29R-2, 99-102 cm; 512.39 mbsf; O42-3; PH. 3. Species 1; 913B-29R-2, 99-102 cm; 512.39 mbsf; O42-3; PH. 4. Species 1; 913B-29R-2, 99-102 cm; 512.39 mbsf; O42-3; PH. 5. Species 2; 913B-33R2, 100-104 cm; 550.90 mbsf; E36; PH. 6. Species 2; 913B-33R-2, 100-104 cm; 550.90 mbsf; E36; PH. 7. Spinidinium sp.; 913B-29R-1, 99-102 cm; 510.89 mbsf; U41-4; PH. 8. Species 2; 913B-28R-1, 35-38 cm; 500.65 mbsf; K44; PH. 9. Species 2; 913B-28R-1, $35-38$ cm; 500.65 mbsf; K44; PH. 

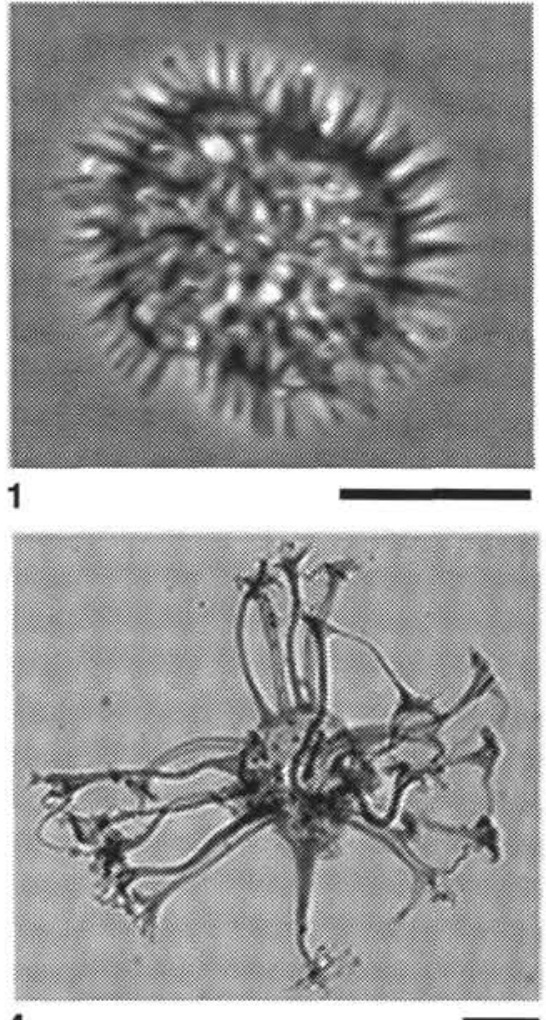

4

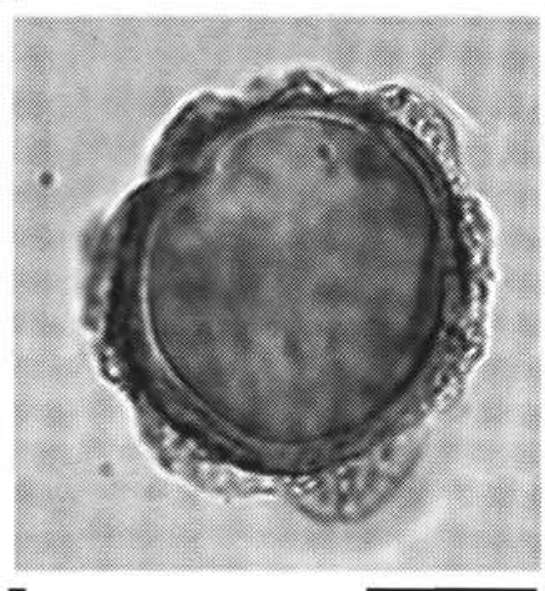

7

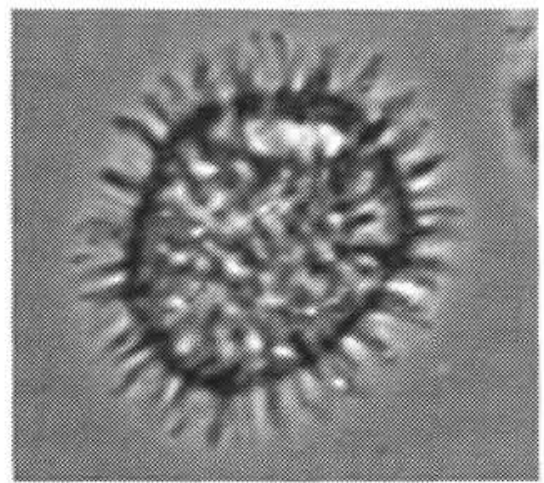

2

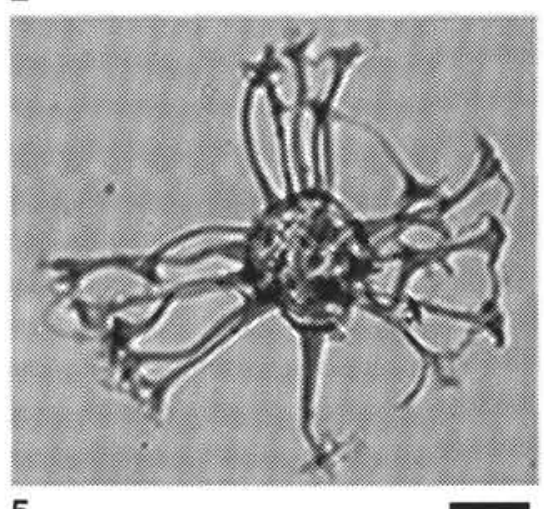

5

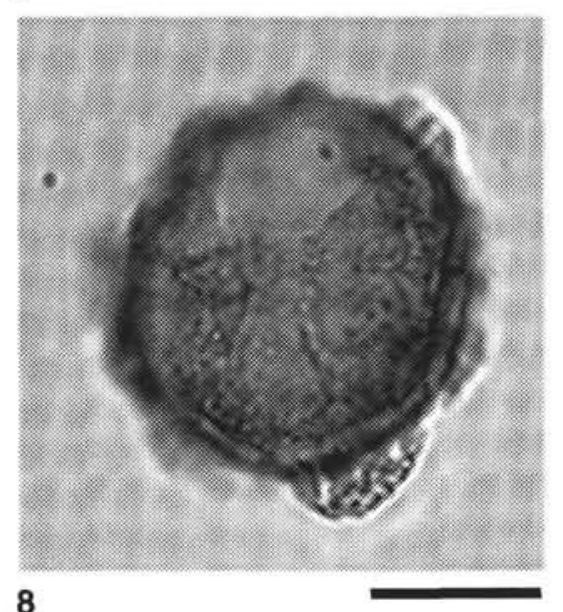

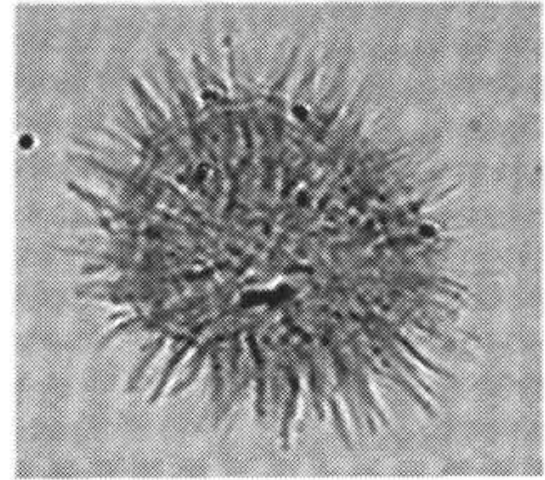

3

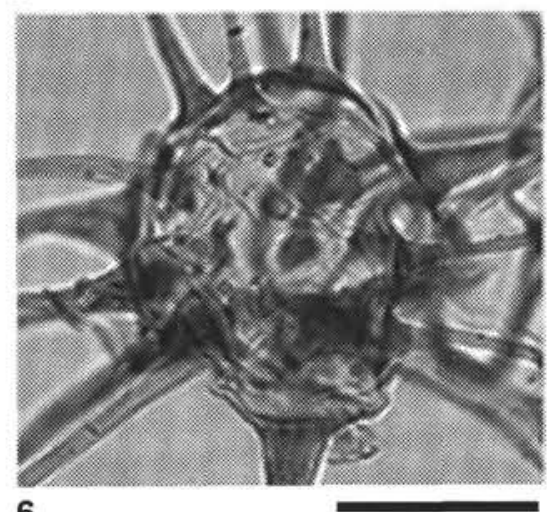

\section{6}

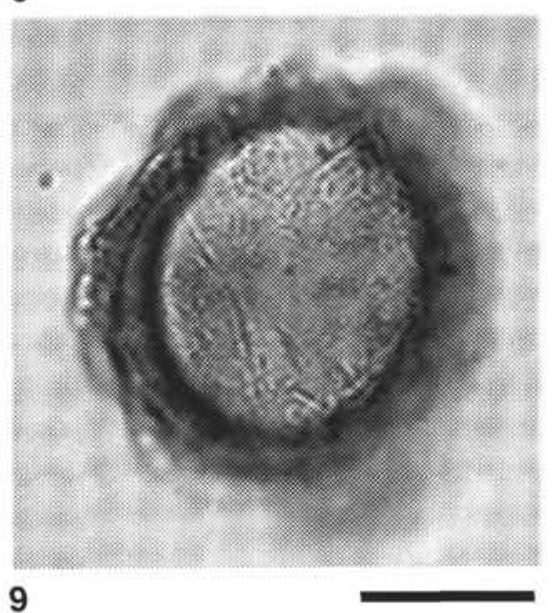

Plate 22. All scale bars $=25 \mu \mathrm{m}$. 1. Species 3; 913B-34R-2, 103-105 cm; $560.68 \mathrm{mbsf}$; S29; PH. 2. Species 3; 913B-34R-2, $103-105 \mathrm{~cm} ; 560.68 \mathrm{mbsf}$; Q34; PH. 3. Species 3; 913B-25R-2, 110-113 cm; 474.20 mbsf; L38; TR. 4. Species 4; 913B-26R-2, 100-102 cm; 483.60 mbsf; Y33-2; TR. 5. Species 4; 913B-26R-2, 100-102 cm; 483.60 mbsf; Y33-2; TR. 6. Species 4; 913B-26R-2, 100-102 cm; 483.60 mbsf; Y33-2; TR. 7. Species 5; 913B-26R-2, 100-102 cm; 483.60 mbsf; U37-4; TR. 8. Species 5; 913B-26R-2, 100-102 cm; 483.60 mbsf; U37-4; TR. 9. Species 5; 913B-26R-2, 100-102 cm; 483.60 mbsf; U37-4; TR. 


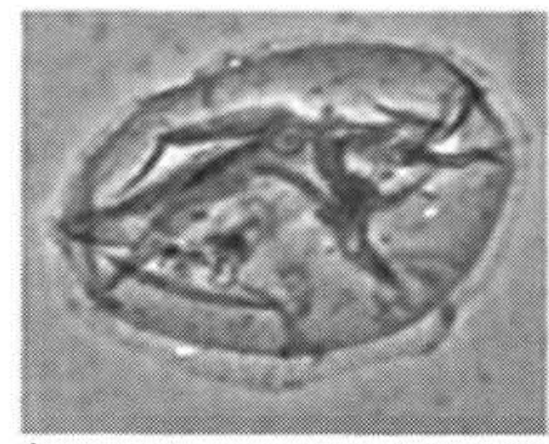

1

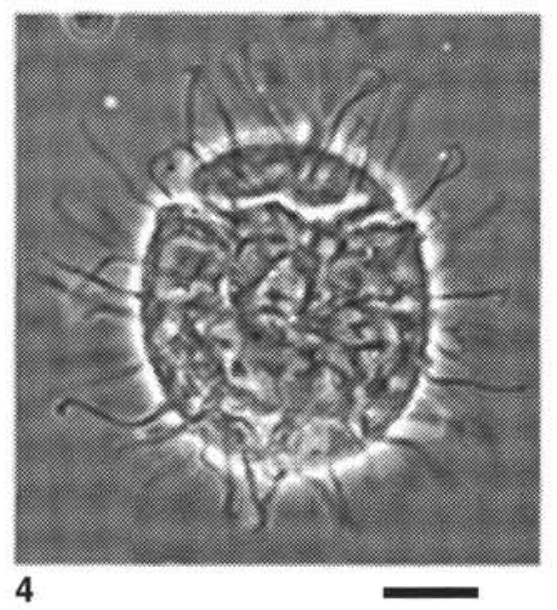

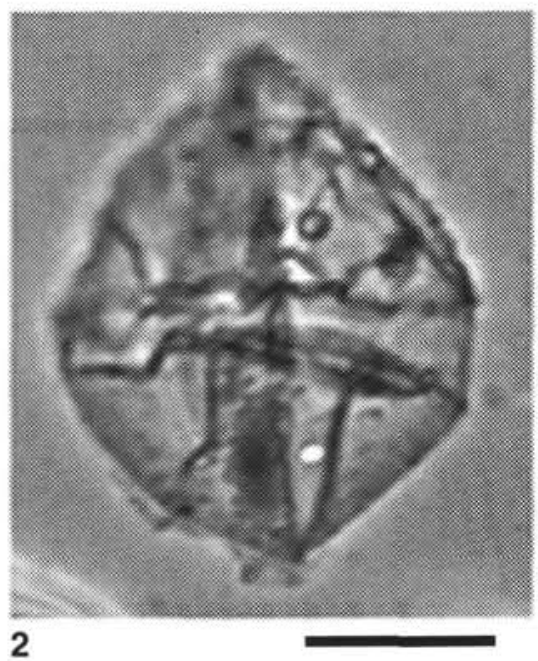

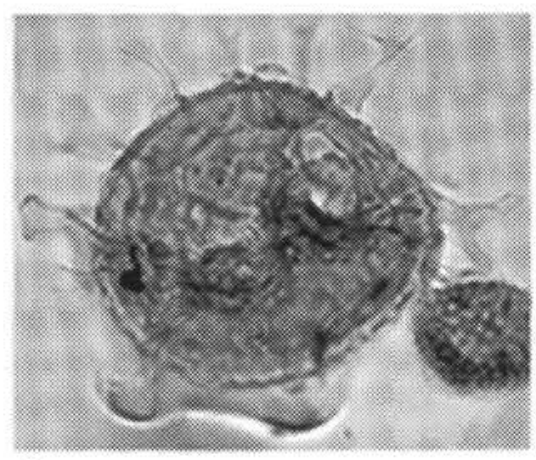

5

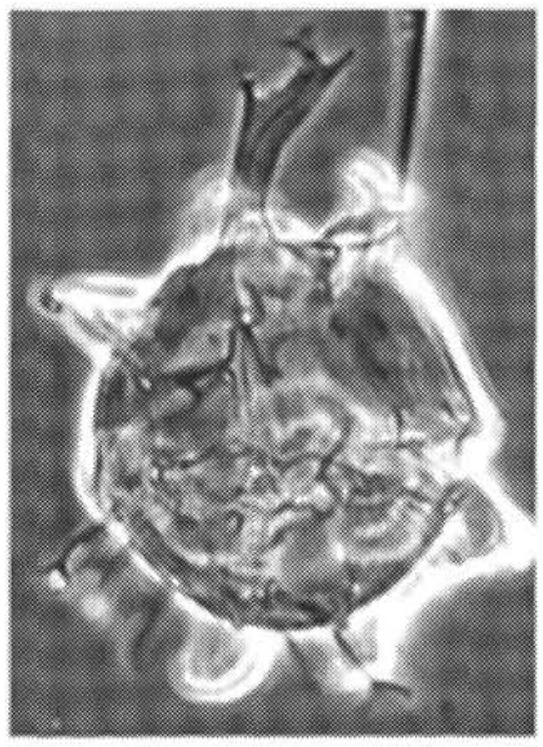

3

Plate 23. All scale bars = $25 \mu \mathrm{m}$. 1. Species 6; 913B-36R-3, 103-105 cm; $581.42 \mathrm{mbsf}$; Q41-3; PH. 2. Species 6; 913B-36R-3, 103-105 cm; 581.42 mbsf; H35; PH. 3. Spiniferites cornutus; 913B-24R-2, 77-79 cm; 464.27 mbsf; D42-4; PH. 4. Systematophora sp.; 913B-24R-2, 77-79 cm; 464.27 mbsf; V33-2; PH. 5. Spiniferites pseudofurcatus; 913B-24R-4, 68-70 cm; $467.18 \mathrm{mbsf}$; E32-2; TR. 


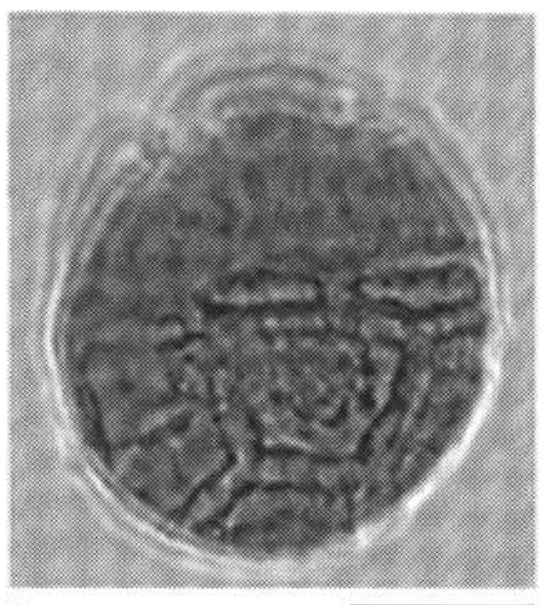

1

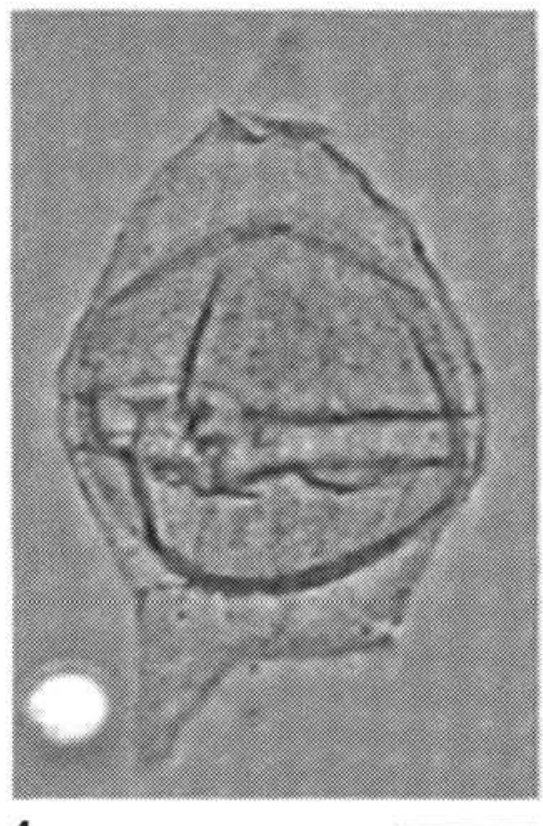

4
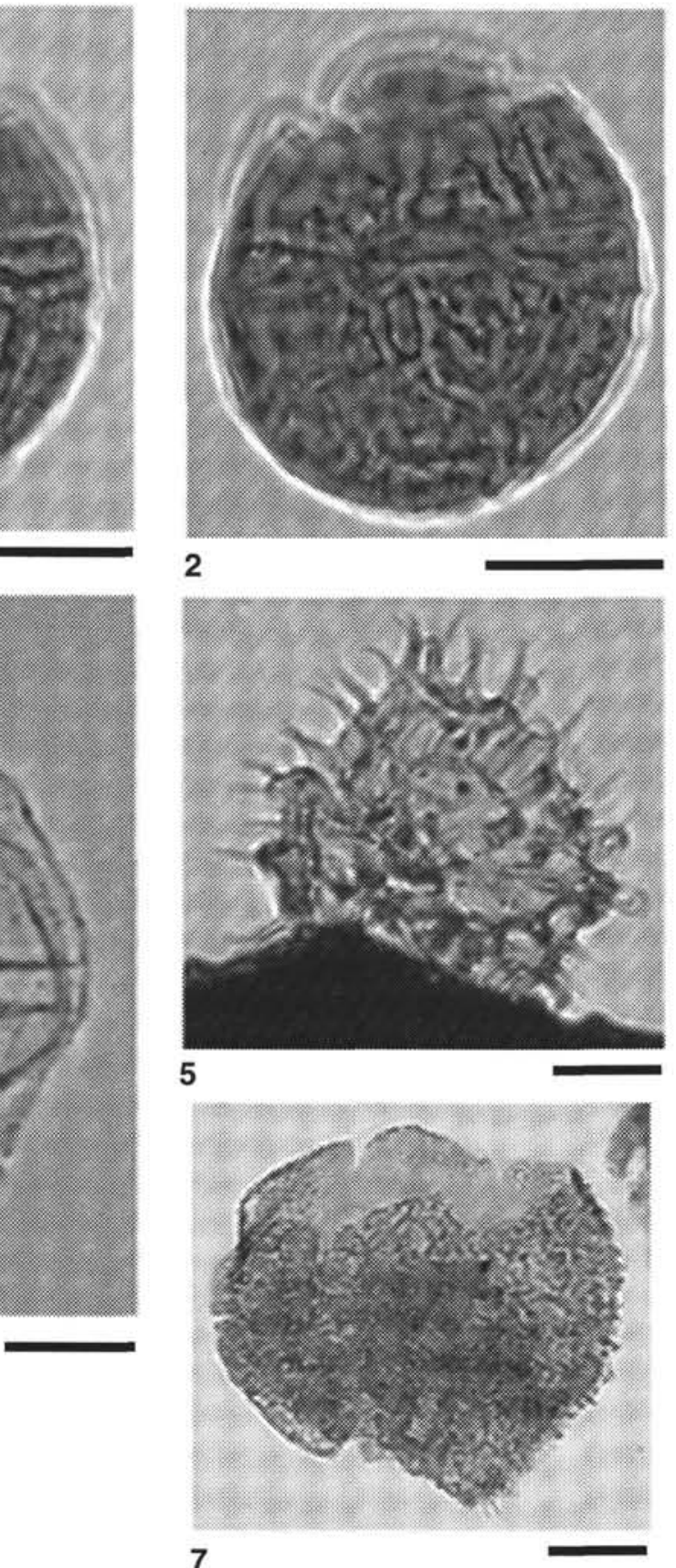

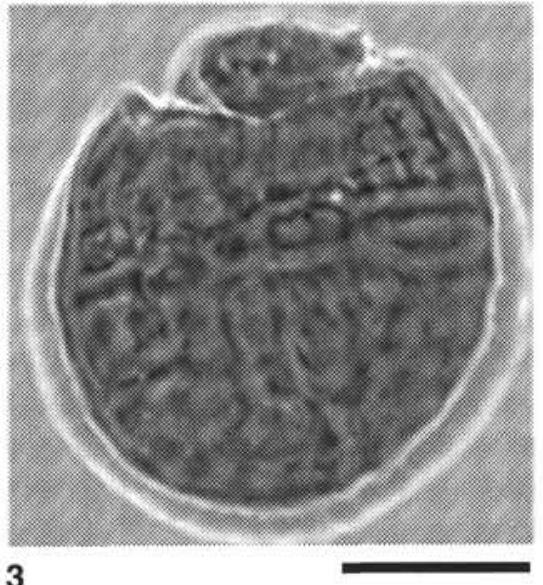

3

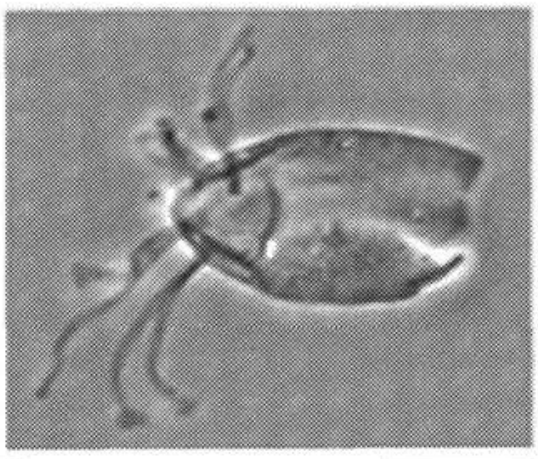

6

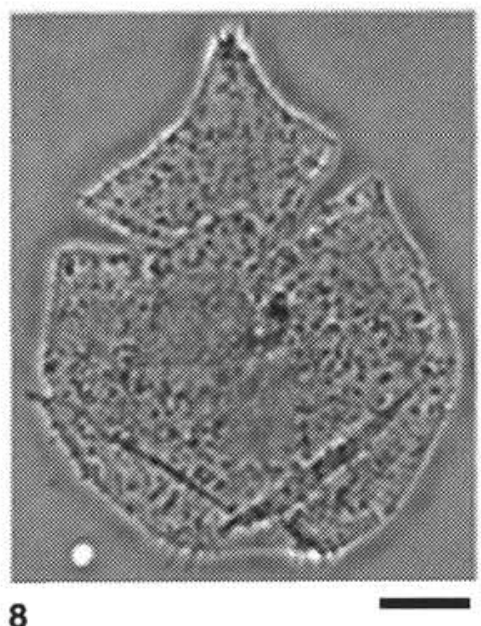

Plate 24. Reworked taxa. All scale bars $=25 \mu \mathrm{m}$. 1. Alisocysta margarita; 913B-24R-2, 77-79 cm; $464.27 \mathrm{mbsf} ; \mathrm{V} 30-2 ; \mathrm{PH}$. 2. Alisocysta margarita; 913B-24R2, 77-79 cm; 464.27 mbsf; V30-2; PH. 3. Alisocysta margarita; 913B-24R-2, 77-79 cm; 464.27 mbsf; V30-2; PH. 4. Alterbidinium sp.; $913 \mathrm{~B}-20 \mathrm{R}-2$, 98-102 cm; 425.98 mbsf; J31-1; PH. 5. Apectodinium sp.; 913B-20R-2, 98-102 cm; 425.98 mbsf; K44-1; TR. 6. Bourkidinium sp.; 913B-29R-1, 99-102 cm; 510.89 mbsf; U29-4; PH. 7. Canningia? sp. 2; 913B-20R-2, 98-102 cm, 425.98 mbsf; L39-2; TR. 8. Canningia? sp. 1; 913B-24R-5, 54-56 cm; 468.54 mbsf; U26; PH. 

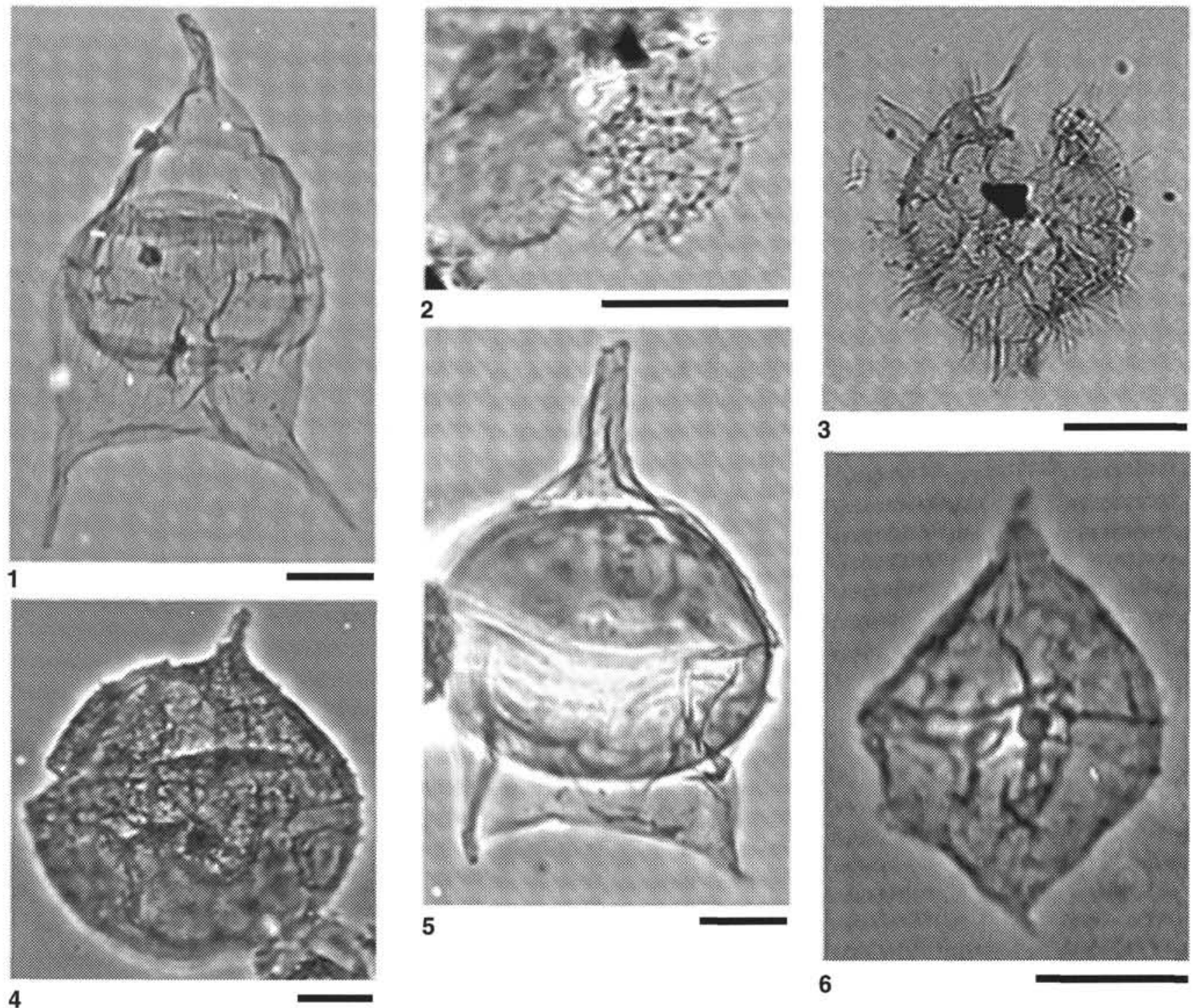

Plate 25. Reworked taxa. All scale bars $=25 \mu \mathrm{m}$. 1. Cerodinium striatum; 913B-31R-1, 99-104 cm; 530.19 mbsf; M36; PH. 2. Comasphaeridium? sp. 1; 913B28R-1, 35-38 cm; 500.65 mbsf; O38-4; PH. 3. Conneximura fimbriata; 913B-26R-6, 100-102 cm; 489.60 mbsf; N37-2; TR. 4. Cribroperidinium sp. 1; $913 \mathrm{~B}-$ 20R-2, 98-102 cm; 425.98 mbsf; K42-1; PH. 5. Deflandrea oebisfeldensis; 913B-29R-2, 99-102 cm; 512.39 mbsf; R37; PH. 6. Diconodinium? sp. 1; 913B20R-3, 95-99 cm; $427.45 \mathrm{mbsf} ; \mathrm{V} 33-3$; PH. 


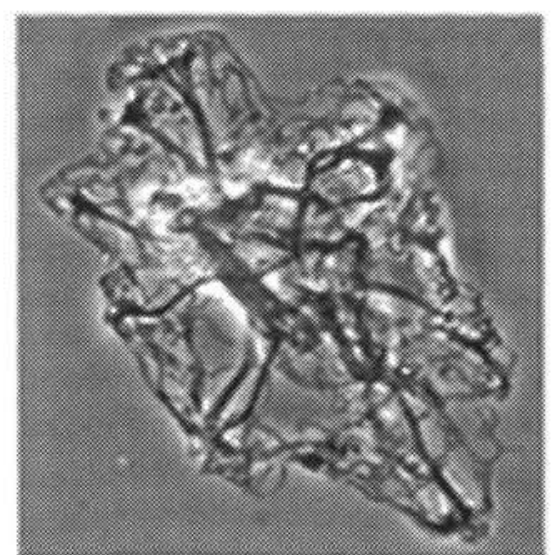

1

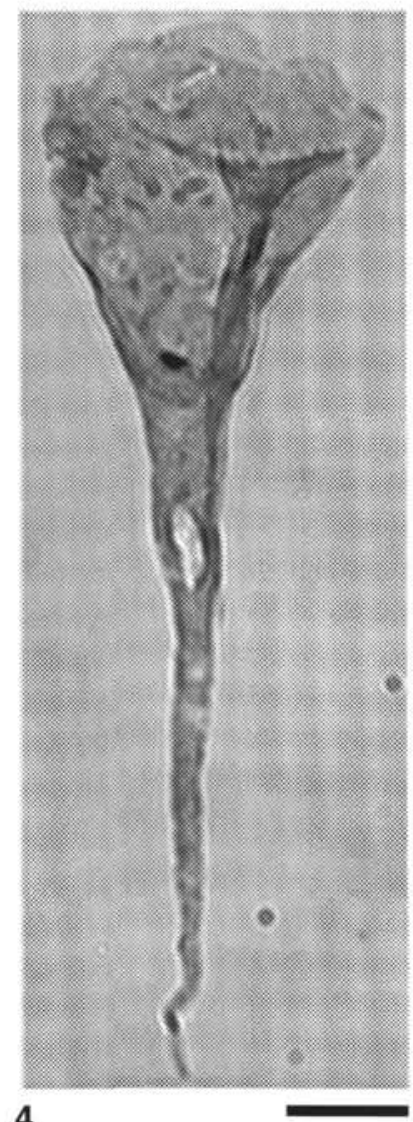

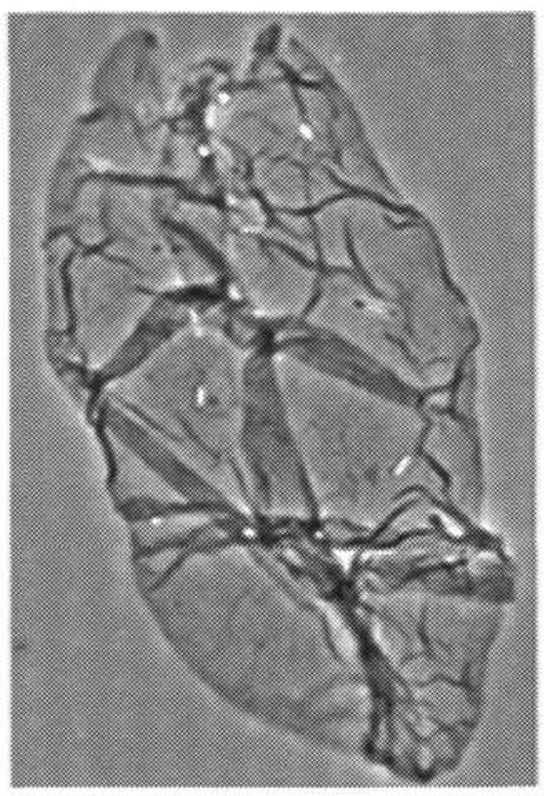

2

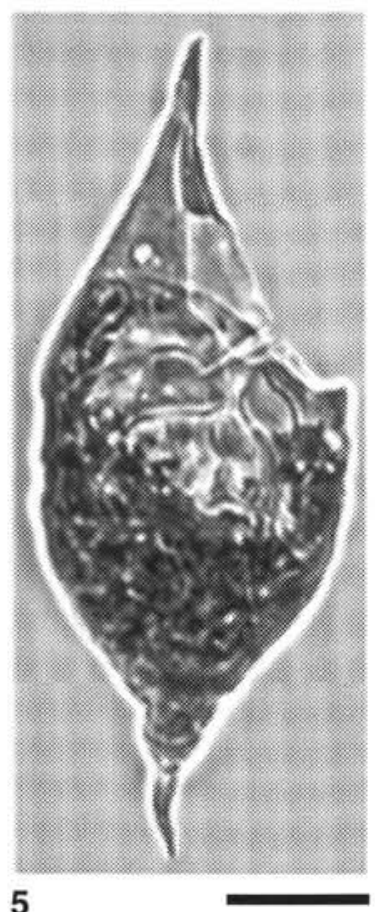

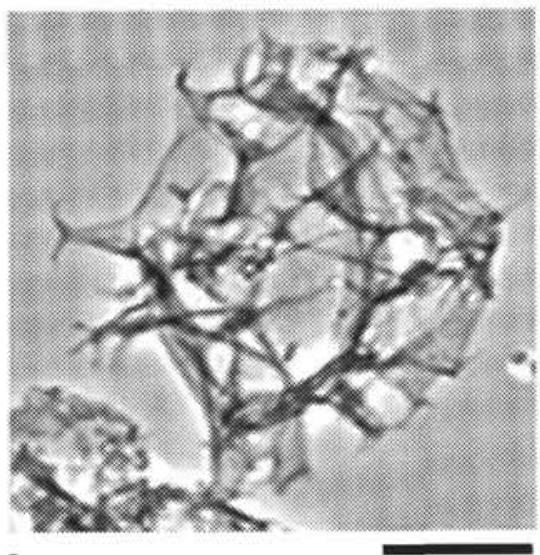

3

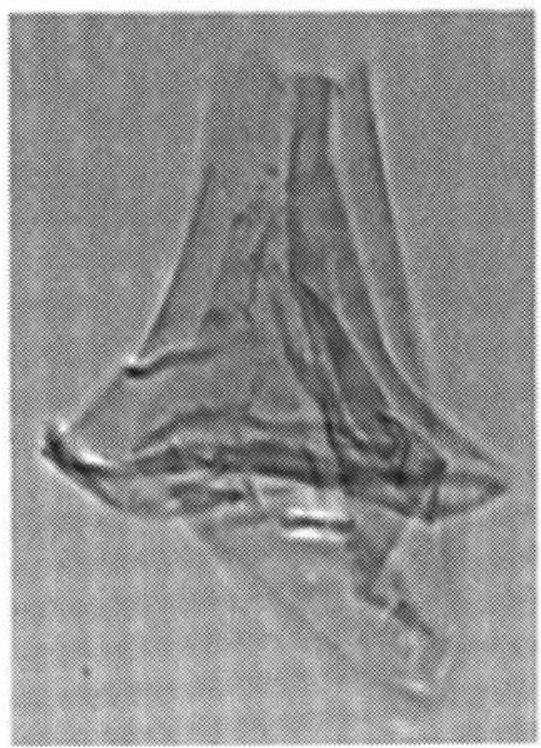

6

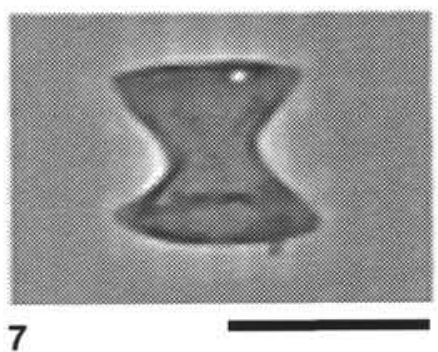

Plate 26. Reworked taxa. All scale bars $=25 \mu \mathrm{m}$, except where noted. 1. Eatonicysta ursulae; 913B-30R-2, 97-101 cm; 521.97 mbsf; U36-4; PH. 2. Fromea fragilis; 913B-29R-2, 99-102 cm; 512.39 mbsf; M36-1; PH. 3. Hystrichostrogylon membraniphorum; 913B-29R-4, 100-103 cm; 515.40 mbsf; P37; TR. 4. Odontochitina sp.; 913B-33R-2, 100-104 cm; 550.90 mbsf; X38-2; TR. 5. Palaeocystodinium bulliformum; scale bar $=50 \mu \mathrm{m} ; 913 \mathrm{~B}-24 \mathrm{R}-1,68-70 \mathrm{~cm} ; 462.68 \mathrm{mbsf}$; H26-4; PH. 6. Palaeotetradinium sp. 1; 913B-31R-1, 99-104 cm; 530.19 mbsf; M30-3; PH. 7. Horologinella sp. 1; 913B-31R-1, 99-104 cm; 530.19 mbsf; G36; $\mathrm{PH}$. 


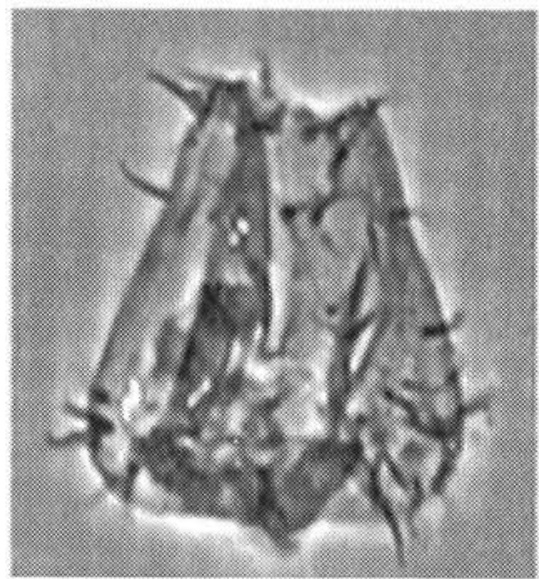

1

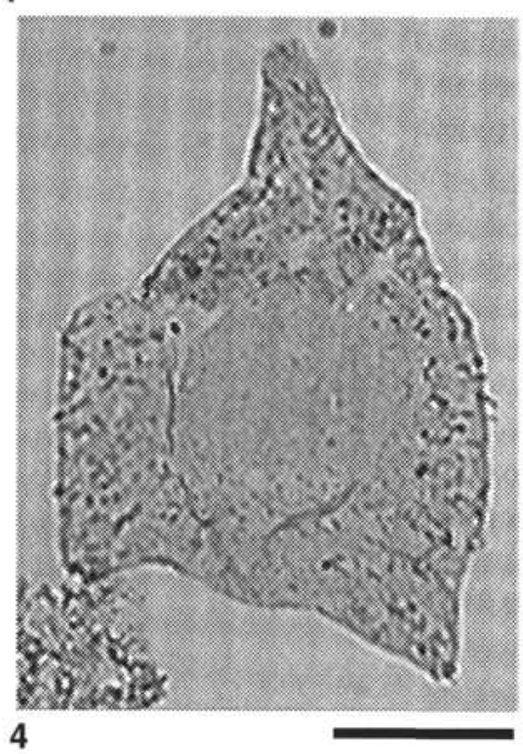

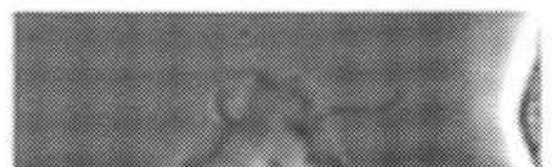

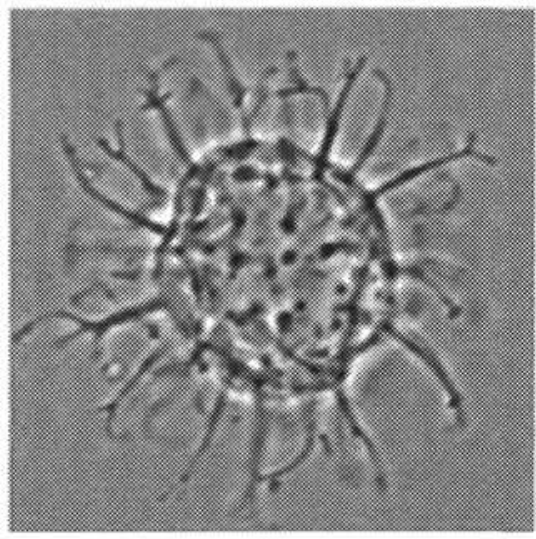

3

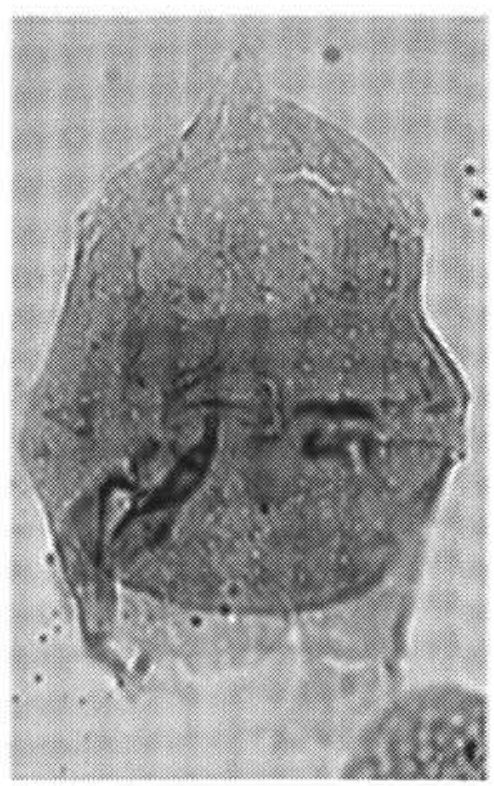

6

Plate 27. Reworked taxa. All scale bars $=25 \mu \mathrm{m}$. 1. Rhombodella paucispina; $913 \mathrm{~B}-28 \mathrm{R}-1,35-38 \mathrm{~cm} ; 500.65 \mathrm{mbsf} ; \mathrm{R} 33-2 ; \mathrm{PH}$. 2. Palaeohystrichophora infusorioides; 913B-20R-2, 98-102 cm; 425.98 mbsf; F35; PH. 3. Surculosphaeridium? longifurcatum; 913B-24R-2, 77-79 cm; 464.27 mbsf; E31; PH. 4. Pseudoceratium sp. 1; 913B-20R-2, 98-102 cm; 425.98 mbsf; F39-3; TR. 5. Tanyosphaeridium sp. 1; 913B-24R-5, 54-56 cm; 468.54 mbsf; N36; PH. 6. Chatangiella sp.; 913B-20R-3, 95-99 cm; 427.45 mbsf; N38-4; TR. 